\title{
AVALIAÇÃO DOS PROBLEMAS AMBIENTAIS RELACIONADOS AOS ASPECTOS GEOLÓGICO- GEOTÉCNICOS E DUTOS ENTERRADOS, POLIDUTO OSBRA: TRECHO PORTO FERREIRA - RIBEIRÃO PRETO
}

\section{JOSELI FERREIRA}

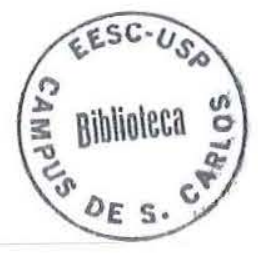

Dissertação apresentada à Escola de Engenharia de São Carlos da Universidade de São Paulo, como parte dos requisitos para obtenção do título de Mestre em Geotecnia.

ORIENTADOR: Prof. Dr. Lázaro Valentin Zuquette 
Class. TESE-EE KC

Gutt.

2147

Tombo

$51 / 5 \cdot 1048050$

Ficha catalográfica preparada pela Seção de Tratamento

da informação do Serviço de Biblioteca - EESC-USP

B383a Ferreira, Joseli aspectos geológico-geotécnicos e dutos enterrados, poliduto OSBRA: trecho Porto Ferreira - Ribeirão Preto / Joseli Ferreira. São Carlos, 1999.

Dissertação (Mestrado) - Escola de Engenharia de São Carlos - Universidade de São Paulo, 1999.

Orientador: Prof. Dr. Lázaro Valentin Zuquette

1. Geotecnia Ambiental. I.Título. 


\section{AGRADECIMENTOS}

Acima de tudo a Deus, pelo eterno amor e infinita misericórdia.

Ao prof. Dr. Lázaro Valentin Zuquette, pela orientação e amizade.

À Coordenadoria de Aperfeiçoamento de Pessoal de Nível Superior - CAPES, pela bolsa de estudo concedida e à FAPESP pela concessão de verba através do Projeto 98/11320-4.

Aos professores, funcionários e colegas do Departamento de Geotecnia da EESCUSP pelo auxílio durante a elaboração deste trabalho.

Às amigas Janaina Barrios Palma e Vanessa Madrucci pelo companheirismo e estímulo.

À Sayonara Brederode Ferreira pela troca de conhecimentos e apoio na finalização deste trabalho.

À minha irmã Juliana e aos meus sobrinhos Ramon, Camila e Alexandre pelo amor e compreensão durante minha ausência em tantos momentos importantes.

$\mathrm{E}$ a todos que, direta ou indiretamente, contribuíram para a realização desta etapa, em especial aos amigos da sala de mapeamento e às companheiras da Green House. 


\section{SUMÁRIO}

LISTA DE FIGURAS

LISTA DE TABELAS

LISTA DE ABREVIATURAS E SIGLAS vi

LISTA DE SÍMBOLOS vii

RESUMO ix

ABSTRACT $x$

CAPÍTULO 1 - Considerações Inicias.................................................................... 01

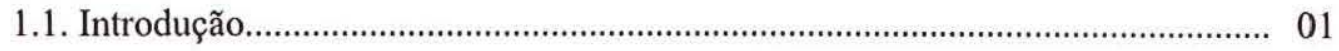

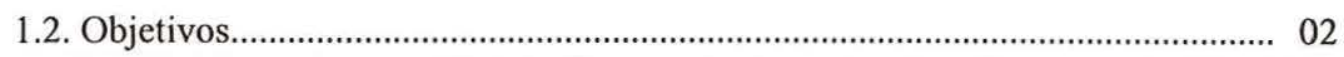

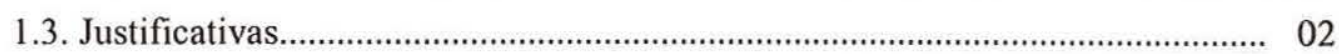

CAPÍTULO 2 - Revisão Bibliográfica.................................................................. 07

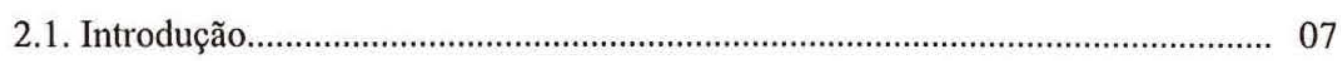

2.2. Características Gerais dos Dutos....................................................................... 07

2.2.1 Problemas mais comuns........................................................................... 08

2.2.1.1. Corrosividade.......................................................................... 09

2.2.1.2. Abalos sísmicos................................................................... 10

2.3. Produtos Compostos de Hidrocarbonetos......................................................... 10

2.3.1. Petróleo bruto................................................................................... 10

2.3.2. Derivados de petróleo............................................................................. 10

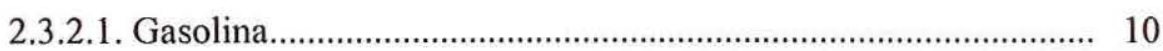

2.3.2.2. Óleos brutos............................................................................. 13

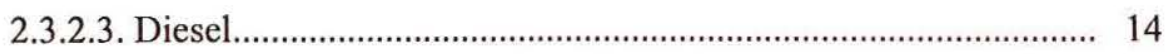

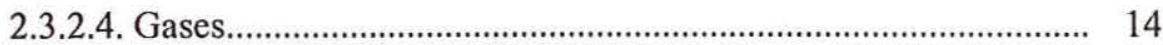

2.3.3. Propriedades dos compostos de hidrocarbonetos.................................... 15

2.3.3.1. Solubilidade ............................................................................... 15

2.3.3.2. Pressão de Vapor..................................................................... 16

2.3.3.3. Densidade................................................................................ 17

2.3.3.4. Viscosidade Dinâmica................................................................... 18

2.4. Formas de Transporte do Produto em Meio Poroso............................................ 18

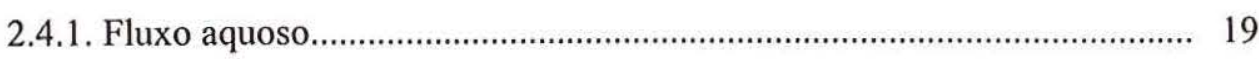

2.4.2. Fluxo não aquoso............................................................................. 19 
2.4.2.1. Fase líquida não aquosa leve................................................... 19

2.4.2.2. Fase líquida não aquosa densa..................................................... 20

2.5. Comportamento da Fase Líquida Não Aquosa................................................... 20

2.5.1. Fatores do meio físico que afetam o transporte do NAPL........................ 20

2.5.1.1. Grau de saturação........................................................................... 23

2.5.1.2. Permeabilidade relativa........................................................... 23

2.5.2. Retenção do Contaminante..................................................................... 25

2.5.3. Comportamento do LNAPL............................................................ 28

2.5.4. Comportamento do DNAPL ........................................................... 31

2.6. Transporte em Fase Aquosa....................................................................... 33

2.6.1. Adveç̧ão......................................................................................... 34

2.6.2.Dispersão hidrodinâmica....................................................................... 35

2.7. Mecanismos de Atenuação dos Produtos Derivados do Petróleo........................ 36

2.7.1. Sorção................................................................................................... 36

2.7.1.1. Adsorção de hidrocarbonetos..................................................... 36

2.7.2. Bioremediação.................................................................................. 39

2.8. Principais Técnicas de Remediação................................................................. 41

2.9. Modelagem Numérica................................................................................... 43

2.9.1. Tipos de Modelos.............................................................................. 43

2.9.1.1. Modelos analíticos....................................................................... 44

2.9.1.2. Modelos de meios porosos........................................................... 44

2.9.1.3. Modelos de fluxo viscoso........................................................... 44

2.9.1.4. Modelos de membrana................................................................ 45

2.9.1.5. Modelos de analogia elétrica.................................................. 46

2.9.1.6. Modelos empíricos................................................................ 46

2.9.1.7. Modelos de balanço de massa................................................... 47

2.9.1.8. Modelos numéricos................................................................. 47

2.9.2. Etapas de criação de um modelo numérico............................................ 47

2.9.2.1. Compilação e interpretação dos dados de campo.......................... 48

2.9.2.2. Entendimento do meio físico......................................................... 48

2.9.2.3. Conceituação do meio físico......................................................... 48

2.9.2.4. Seleção do modelo numérico.................................................... 48

2.9.2.5. Calibragem e validação do modelo............................................. 50

2.9.2.6. Aplicação do modelo............................................................... 50

2.9.2.7. Apresentação dos resultados.................................................. 50 
CAPÍTULO 3 - Metodologia........................................................................ 51

3.1. Considerações Iniciais........................................................................................ 51

3.2. Revisão bibliográfica.................................................................................... 51

3.3.Definição do traçado do duto............................................................................ 53

3.4. Coleta e obtenção de informações...................................................................... 53

3.4.1. Etapa de campo............................................................................. 59

3.5. Elaboração dos documentos cartográficos......................................................... 59

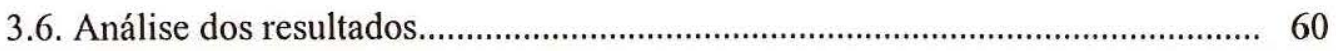

3.7. Modelagem de compostos orgânicos............................................................ 60

3.7.1. Aplicação do programa computacional modflow..................................... 61

3.7.2. Problemas relacionados à modelagem de compostos orgânicos.............. 61

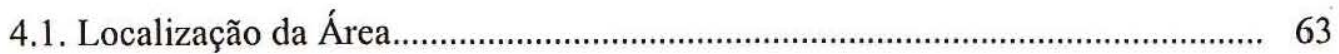

4.2. Características Físicas e Distribuição dos Componentes do Duto...................... 64

4.3. Características dos Produtos Transportados......................................................... 69

4.3.1 Gás Liqüefeito de Petróleo - GLP.......................................................... 69

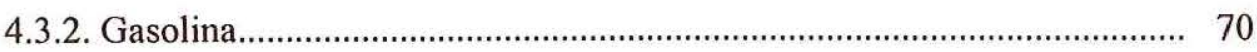

4.3.3. Álcool anidro e hidratado................................................................... 71

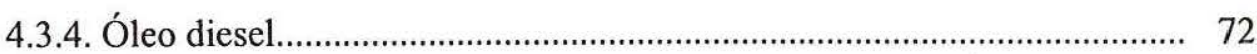

4.3.5.Querosene de aviação................................................................................ 73

4.4. Características do Meio Físico.......................................................................... 73

4.4.1. Geologia da área................................................................................ 73

4.4.1.1. Formação Corumbataí................................................................. 75

4.4.1.2. Formação Pirambóia...................................................................... 77

4.4.1.3. Formação Botucatu......................................................................... 78

4.4.1.4. Formação Serra Geral............................................................ 78

4.4.2. Materiais inconsolidados.................................................................... 79

4.4.2.1.Aluviões................................................................................... 80

4.4.2.2. Materiais hidromórficos............................................................ 80

4.4.2.3. Materiais residuais arenosos..................................................... 80

4.4.2.4. Materiais residuais argilosos..................................................... 80

4.4.2.5. Materiais mistos....................................................................... 80

4.4.2.5.1. Argilosos........................................................................ 81

4.4.2.5.2. Arenosos e argilosos................................................... 81

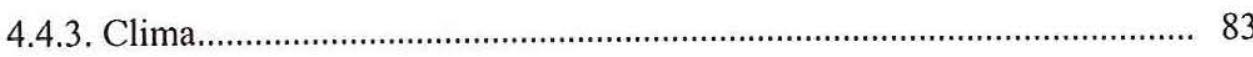




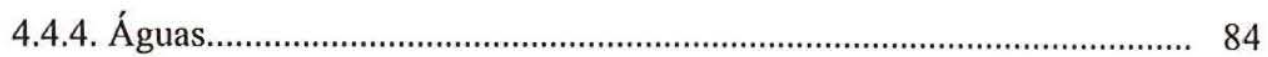

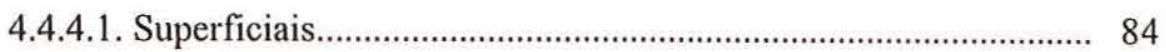

4.4.4.2. Subsuperficiais........................................................................... 84

4.4.4.2.1. Aqüífero Botucatu......................................................... 85

4.4.4.2.2. Aqüífero Pirambóia........................................................ 85

4.4.4.2.3. Aqüífero Serra Geral......................................................... 85

4.4.5. Vegetação........................................................................................... 86

4.4.6. Meio Antrópico.................................................................................. 86

CAPÍTULO 5 - Análise dos Resultados.................................................................. 87

5.1. Considerações Iniciais....................................................................................... 87

5.2. Condições de Instabilização do duto................................................................... 88

5.2.1. Falhas estruturais.................................................................................. 88

5.2.2. Atividades antrópicas........................................................................ 89

5.2.3. Interações entre meio físico e duto.......................................................... 89

5.2.3.1. Corrosividade........................................................................... 90

5.2.3.2. Expansibilidade....................................................................... 91

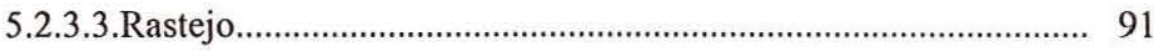

5.2.3.4. Colapsividade........................................................................... 92

5.2.3.5. Erosão..................................................................................... 94

5.3. Avaliação dos Problemas de Poluição das Águas.................................................. 97

5.3.1. Perigo de explosão e incêndio................................................................. 97

5.3.2. Águas subsuperficiais.............................................................................. 98

5.3.3. Águas superficiais................................................................................ 100

5.3.4. Perfis esquemáticos............................................................................... 100

5.3.4.1. Perfil 1.................................................................................. 100

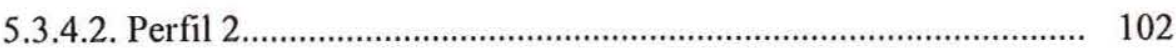

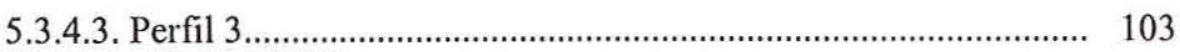

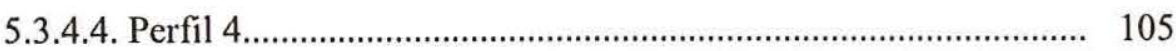

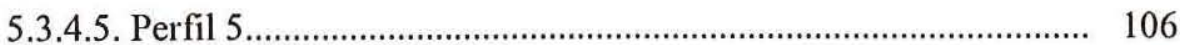

CAPÍTULO 6 - Considerações Finais............................................................... 108

CAPÍTULO 7 - Bibliografia ........................................................................ 111 


\section{LISTA DE FIGURAS}

FIGURA 1: Distribuição dos dutos no Brasil (PETROBRÁS, 1997).

FIGURA 2: Esquema da ocorrência de diferentes fases em zona saturada e não saturada (A) e em zona não saturada (B) (EPA, 1989, 1991).

FIGURA 3: Saturação residual resultando em (A) saturação pendular e (B) saturação insular (EPA, 1991).

FIGURA 4: Curvas de permeabilidade relativa para a água e o NAPL (SCHWILLE, 1988).

FIGURA 5: Transporte do LNAPL na zona não saturada e sobre a franja capilar (EPA, 1991)

FIGURA 6: Depressão do nível de água subsuperficial resultando em (A) grande frente de LNAPL, e (B) elevação do nível d'água (EPA, 1991).

FIGURA 7: Partição do DNAPL na fase de vapores densos e de compostos dissolvidos (EPA, 1991).

FIGURA 8: Percolação do DNAPL através de fraturas em material impermeável (EPA, 1991).

FIGURA 9: Esquema de uma pluma de hidrocarbonetos típica tratada por bioremediação natural (NORRIS, 1994\}

FIGURA 10: Exemplos de modelos de água subsuperficial (SPITZ \& MORENO, 1996)

FIGURA 11: Exemplos de algumas das principais fases de elaboração de um modelo numérico (SPITZ \& MORENO, 1996).

FIGURA 12: Fluxograma da metodologia proposta......

FIGURA 13: Localização da área. 
FIGURA 14: Base de distribuição de Ribeirão Preto

FIGURA 15: Detalhe do revestimento das paredes do duto

FIGURA 16a: Juntas sem revestimento

FIGURA 16b: Detalhe das juntas revestidas.

FIGURA 17: Bomba de movimentação dos produtos transportados.

FIGURA 18: Válvula de segurança.

FIGURA 19: Trincheira

FIGURA 20: Duto instalado na trincheira

FIGURA 21: Vista do alinhamento do duto sobre a Formação Corumbataí.

FIGURA 22: Camadas sílticas e argilosas da Formação Corumbatai em contato com material transportado.

FIGURA 23: Detalhe da Formação Corumbataí recoberta por material inconsolidado areno-argiloso retrabalhado

FIGURA 24: Formação Botucatu.

FIGURA 25: Formação Serra Geral

FIGURA 26: Fatores considerados na análise dos resultados.

FIGURA 27: Válvula situada na planície de inundação do Rio Claro.

FIGURA 28: Detalhe da válvula

FIGURA 29: Detalhe do processo de rastejo.

FIGURA 30: Feição erosiva em estrada secundária na região de Cravinhos 
FIGURA 32: Erosão na faixa de servidão........................................................................ 96

FIGURA 33: Perfil esquemático 1............................................................................. 101

FIGURA 34: Perfil esquemático 2............................................................................... 102

FIGURA 35: Perfil esquemático 3 3........................................................................... 104

FIGURA 36: Perfil esquemático 4 ............................................................................. 105

FIGURA 37: Perfil esquemático 5................................................................................... 107 


\section{LISTA DE TABELAS}

TABELA 1: Acidentes ocorridos nos Estados Unidos no período de 1971 a 1980

(CONCAWE, sd)

TABELA 2: Classificação dos 158 acidentes quanto ao processos de ocorrência (CONCAWE, s.d.)

TABELA 3: Composição química de uma gasolina comum (JOHNSON et al., 1990)..

TABELA 4: Composição média da gasolina (PETROBRÁS, 1996).

TABELA 5: Limites de concentração de contaminantes orgânicos em água potável (FETTER, 1993).

TABELA 6: Propriedades químicas de alguns compostos orgânicos. (Modificado de SPITZ \& MORENO, 1996).

TABELA 7: Densidade e solubilidade dos LNAPLs (FETTER, 1994).

TABELA 8: Valores típicos de K para os solos (DIETZ,1970 e CONCAWE, 1979)....

TABELA 9: Capacidade de retenção em óleo em solos não saturados (CONCAWE, 1979)

TABELA 10: Atributos que devem ser levantados de acordo com ZUQUETTE (1997) no processo de mapeamento geotécnico, a partir dos quais podem ser analisados os problemas ambientais relacionados as características geológico-geotécnicas em termos dos dutos. Modificado de ZUQUETTE (1997).

TABELA 11: Propriedades físico-químicas e termodinâmicas do GLP.

TABELA 12: Dados de inflamabilidade do GLP

TABELA 13: Coluna estratigráfica da área estudada. Modificada de DAEE (1975) e PETRI \& FÚLFARO (1982). 
TABELA 14: Índices adotados para tipo de material inconsolidado

TABELA 15: Índices adotados para tipos rochosos.

TABELA 16: Índices adotados para classes de profundidade de substrato rochoso.

TABELA 17: Índices adotados para classes de nível de água.

TABELA 18: Esquema de classificação das unidades de zoneamento.

TABELA 19: Características dos 2 principais rios interceptados pelo duto. Modificado de DAEE (1975)

TABELA 20: Critérios de identificação de solos colapsíveis utilizando-se $\rho_{d}$ e $s_{r}$ Modificado de Neves (1987). 


\section{LISTA DE ABREVIATURA E SIGLAS}

BTEX: Benzeno, Tolueno, Etilbenzeno e Xilenos

CETESB: Companhia de Tecnologia de Saneamento Ambiental

DAEE: Departamento de Águas e Energia Elétrica

DNAPL: Dense Nonaquous Phase Liquid - Fase Líquida Não Aquosa Densa

EESC/USP: Escola de Engenharia de São Carlos/Universidade de São Paulo

EPA (USEPA): Environmental Protection Agency - Agência de Proteção Ambiental dos Estados Unidos.

FBE: Fusion Bonded Epoxi

GLP: Gás Liqüefeito de Petróleo

IBGE: Instituto Brasileiro de Geografia

IPT: Instituto de Pesquisas Tecnológicas

LNAPL: Light Nonaquous Phase Liquid - Fase Líquida Não Aquosa Leve

MTBE: Metil terc - butil éter

NAPL: Nonaquous Phase Liquid - Fase Líquida Não Aquosa

OSBRA: Oleoduto São Paulo-Brasília

REPLAN: Refinaria de Paulínia

RIMA: Relatório de Impacto Ambiental

SNC: Sistema Nervoso Central

SVE: Soil Vapor Extraction

QAV: Querosene de Aviação 


\section{LISTA DE SÍMBOLOS}

$\alpha \quad$ - dispersividade [L]

A - área de infiltração $\left[\mathrm{L}^{2}\right]$

$C_{w} \quad$ - solubilidade do composto em água $\left[\mathrm{M} / \mathrm{L}^{3}\right]$

$C_{i}^{*} \quad$ - concentração de equilíbrio do soluto para o componente $i$ na mistura $\left[\mathrm{M} / \mathrm{L}^{3}\right]$

$C_{i}^{0} \quad$ - concentração de equilíbrio do soluto para o componente $i$ como um composto puro [M/L $\left.\mathrm{L}^{3}\right]$

$\mathrm{C}_{\mathrm{s}} \quad$ - concentração do contaminante adsorvida sobre o sólido [1]

d - distância vertical percorrida pelo produto até atingir o nível de água [L]

d - profundidade da água subsuperficial [L]

D - coeficiente de dispersão $\left[\mathrm{L}^{2} / \mathrm{T}\right]$

$\mathrm{D}_{\mathrm{o}} \quad$ - coeficiente de difusão $\left[\mathrm{L}^{2} / \mathrm{T}\right]$

$e_{o} \quad$ - índice de vazios [1]

$f_{o c} \quad$ - fração de carbono orgânico contida na fase sólida [1]

$\mathrm{F}$ - espessura da fase livre [L]

$\partial h \quad$ - gradiente hidráulico [1]

$\overline{\partial l}$

$K \quad$ - condutividade hidráulica [L/T]

$\mathrm{K}_{d} \quad$ - coeficiente de distribuição da adsorção $\left[\mathrm{L}^{3} / \mathrm{M}\right]$

$K_{H} \quad$ - coeficiente da Lei de Henry [atm.m3/mol]

$K_{o w} \quad$ - coeficiente de partição octanol/água [1]

$n_{e} \quad$ - porosidade efetiva [1]

$\mathrm{P}(\mathrm{n}) \quad$ - porosidade do solo [1]

$P_{\text {org }} \quad$ - pressão parcial de vapor na fase gasosa [atm]

$P_{o r g}^{0} \quad$ - pressão de vapor de um composto orgânico puro [atm]

RS - capacidade de saturação residual [1]

$\mathrm{S} \quad$ - espalhamento máximo da fase livre $\left[\mathrm{L}^{2}\right]$

$\mathrm{S}_{\mathrm{i}} \quad$ - volume de poros ocupados pelo fluido $i\left[\mathrm{~L}^{3}\right]$

$\tau \quad$ - tortuosidade do meio [1] 
v - velocidade linear média $[\mathrm{L} / \mathrm{T}]$

V - volume de hidrocarbonetos infiltrantes $\left[\mathrm{L}^{3}\right]$

$\mathrm{V}_{\mathrm{hc}} \quad$ - volume de hidrocarbonetos descarregados $\left[\mathrm{L}^{3}\right]$

$V_{R} \quad$ - volume de produto retido pelos poros $\left[\mathrm{L}^{3}\right]$

$V_{s} \quad$ - volume de solo necessário para que todo o hidrocarboneto vazado esteja na condição de saturação residual $\left[\mathrm{L}^{3}\right]$

$v_{x} \quad$ - velocidade linear média $[\mathrm{L} / \mathrm{T}]$

$X_{i} \quad$ - fração molar do composto $i$ em uma mistura [1]

$\mathrm{x}_{\text {org }}$ - fração molar do composto orgânico [1]

$\gamma_{i} \quad$ - coeficiente de atividade do composto $i$ na mistura [1]

$\gamma_{w} \quad$ - coeficiente de atividade do composto em água [1]

$\rho_{d} \quad$ - massa específica seca $\left[\mathrm{M} / \mathrm{L}^{3}\right]$ 


\section{RESUMO}

FERREIRA, J. (1999). Avaliação dos problemas ambientais relacionados aos aspectos geológico-geotécnicos e dutos enterrados, poliduto OSBRA: trecho Porto Ferreira Ribeirão Preto. São Carlos, 1999. Dissertação (Mestrado) - Escola de Engenharia de São Carlos, Universidade de São Paulo.

Vazamentos decorrentes de acidentes envolvendo dutos constituem uma fonte potencial de contaminação das águas subsuperficiais, superficiais e dos componentes dos meios físico e biológico, em geral. Neste trabalho são analisados os problemas ambientais decorrentes de possíveis vazamentos dos produtos transportados no poliduto OSBRA, no trecho situado entre Porto Ferreira e Ribeirão Preto (SP). Este trecho está localizado em uma área de intensa ocupação agrícola, atravessando extensa área de recarga da Formação Botucatu e de basaltos fraturados pertencentes à Formação Serra Geral, além de vários canais de drenagem. Todas estas áreas estão, portanto, sujeitas à contaminação em caso de acidentes envolvendo o duto. Neste trabalho são apontados os principais agentes deflagadores de possíveis acidentes no trecho e analisados os diferentes contextos de contaminação de acordo com as características do meio físico e do produto liberado.

Palavras-chave: dutos; vazamentos; hidrocarbonetos; problemas ambientais. 


\begin{abstract}
FERREIRA, J. (1999). Evaluation of environmental problems related to the geologicalgeotechnical aspects and buried pipeline, pipeline OSBRA: link Porto Ferreira and Ribeirão Preto. São Carlos, 1999. Dissertação (Mestrado) - Escola de Engenharia de São Carlos, Universidade de São Paulo.
\end{abstract}

Leakage from pipeline constitute a potential source of groundwater and surface water contamination as well as to geological and biological environment components. In this research the environmental problems due to leaking of petroleum products transported by OSBRA pipeline, which runs between Porto Ferreira and Ribeirão Preto (SP), are analyzed. It is located in an area of intense agricultural management, crossing large and recharge area of Botucatu Formation and fractured basaltic rocks from Serra Geral Formation. All these areas are, therefore, subject to the contamination in case of accidents involving the pipeline. The aim of this research is to analyze the agents responsible by the accidents and to determine the different types of contamination according to the main characteristic of the environment and spill material.

Key words: pipeline; leakage; petroleum products; environmental problems. 


\subsection{INTRODUÇÃO}

Os dutos são uma tecnologia estrategicamente importante à qualquer nação moderna, especialmente para as industrializadas e de grande extensão territorial, pois são utilizados como meio de transporte para água, esgoto, gás natural, óleo bruto, produtos refinados de petróleo, substâncias químicas perigosas, grãos e muitos outros produtos. A importância dos dutos nos países industrializados não é menor do que qualquer outro modo de transporte, excetuando-se talvez as rodovias (LIU, 1996). Esta importância está intimamente relacionada ao potencial que os dutos oferecem em solucionar e reduzir os volumes de materiais transportados por meio de rodovias e ferrovias.

No entanto, um estudo realizado por HOVEY \& FARMER (1996) indicou uma frequiência de acidentes com dutos da ordem de 214 a 234 acidentes por ano, em um período de sete anos, nos Estados Unidos.

Os acidentes envolvendo dutos constituem uma fonte potencial de contaminação das águas subsuperficiais, superficiais e dos componentes dos meios físico e biológico, em geral. Este fato está intimamente relacionado com a peculiaridade que os dutos apresentam quanto ao aspecto longitudinal, podendo atravessar várias cidades, propriedades rurais e industriais, estradas, diversas bacias hidrográficas, e extensas áreas de recarga. Portanto, os dutos são normalmente classificados como fontes não pontuais de contaminação, devido a sua extensão e distribuição espacial.

I Caso ocorra vazamentos, é de suma importância conhecer as características físicoquímicas dos materiais liberados e o seu comportamento de acordo com os materiais e as estruturas geológicas presentes na área, bem como as possíveis interações entre as partículas dos solos e das rochas e os constituintes contaminantes.

I O risco de contaminação está relacionado com o tipo de produto liberado e os níveis de concentração que atingem o meio ambiente. 
É importante ressaltar que dos produtos normalmente transportados por meio dos dutos, os hidrocarbonetos são os que mais têm afetado a qualidade das águas subsuperficiais. Considerando o potencial de risco ao meio ambiente e os níveis máximos permitidos em termos de qualidade das águas é fundamental o conhecimento sobre o comportamento dos hidrocarbonetos e os materiais (massa-constituinte) do meio físico quanto ao fluxo e o estudo das situações predisponentes ao risco favorecerem a adoção de medidas preventivas de controle, mitigadoras e construtivas.

\subsection{Objetivos}

O objetivo deste trabalho foi investigar as características geológico-geotécnicas do meio físico, juntamente com as características físicas e de funcionamento dos dutos e assim delimitar áreas de vulnerabilidade potencial à contaminação no caso de rompimentos, para o trecho do poliduto OSBRA situado entre as cidades de Porto Ferreira e Ribeirão Preto.

Buscou-se também, com este estudo, prever o comportamento do meio físico de modo a avaliar as possíveis reações do mesmo frente a ocorrência de possíveis vazamentos. Esse evento causaria grandes danos ao meio ambiente provocando modificações intensas na dinâmica da área atingida, podendo produzir perdas além do limite aceitável.

Outro objetivo foi apresentar uma metodologia aplicada à investigação e a análise de problemas ambientais relacionadas a dutos, uma vez que até o presente não existia uma metodologia que orientasse este tipo de estudo.

\subsection{Justificativas}

O grande número de ocorrência de acidentes causados pelo rompimento de dutos provocando vazamentos superficiais ou subsuperficiais, foi um dos fatores a impulsionar o desenvolvimento da pesquisa em torno desse tema.

Pode-se observar na Tabela 1 a ocorr6encia de 158 acidentes envolvendo dutos e estações de bombeamento, nos Estados Unidos, em um período de 10 anos. Destes 158 acidentes $82,9 \%$ atingiram dutos e $17,09 \%$ estações de bombeamento numa relação de 1,32 acidentes/mês. Considerando-se o comprimento da rede atingida, nota-se que o número de acidentes por quilômetro é muito elevado, isto é 1 a cada 1.330 quilômetros. Outro fator importante é o volume de produto recuperado, apenas $29,09 \%$. 
TABELA 1: Acidentes ocorridos nos Estados Unidos no período de 1971 a 1980 (CONCAWE, sd)

\begin{tabular}{|c|c|c|c|c|c|c|}
\hline \multirow[b]{2}{*}{ ANO } & \multicolumn{3}{|c|}{ Número de Acidentes } & \multirow[b]{2}{*}{$\begin{array}{l}\text { Comprimento da } \\
\text { Rede }\left(\mathrm{Km}^{*} 1000\right)\end{array}$} & \multicolumn{2}{|c|}{ Média Volumétrica por Acidente $\left(\mathrm{m}^{3}\right)$} \\
\hline & Estação de Bombeamento & Duto & Total & & $\begin{array}{c}\text { Volume Médio de Produto } \\
\text { Derramado }\end{array}$ & $\begin{array}{c}\text { Volume Médio de Produto } \\
\text { Recuperado }\end{array}$ \\
\hline 1971 & 4 & 7 & 11 & 12,80 & 322 & 30 \\
\hline 1974 & 3 & 15 & 18 & 17,35 & 108 & 60 \\
\hline 1975 & 6 & 14 & 20 & 17,90 & 20 & 4,7 \\
\hline 1976 & 1 & 13 & 14 & 18,10 & 226 & 120 \\
\hline 1977 & 5 & 14 & 19 & 18,40 & 259 & 164 \\
\hline Total & 27 & 131 & 158 & 174,15 & $225 \mathrm{~m}^{3} / \mathrm{ano}$ & $65,47 \mathrm{~m}^{3} / \mathrm{ano}$ \\
\hline
\end{tabular}

- Porcentagem de produto recuperado: $29,09 \%$

- Número de acidentes por mês: 1,32

- Número de acidentes por quilômetro: 1 a cada $1330 \mathrm{Km}$ 
A Tabela 2 mostra que a maioria destes acidentes foi provocada por corrosão $(34,9 \%)$, seguida pelas atividades terciárias $(32,2 \%)$ e pelas falhas mecânicas $(22,2 \%)$.

Supõe-se que o número de acidentes envolvendo dutos tenha aumentado consideravelmente, visto que hoje em dia existe maior quantidade de linhas dutoviárias instadas em função do aumento na demanda de combustíveis, tanto em termos nacionais quanto internacionais.

TABELA 2: Classificação dos 158 acidentes quanto ao processos de ocorrência (CONCAWE, s.d.).

\begin{tabular}{|c|c|}
\hline CATEGORIAS & $(\%)$ \\
\hline Falha Mecânica & 22,2 \\
\hline Falha na construção & 7,6 \\
\hline Falha no material & 14,6 \\
\hline Erro Operacional & 5,7 \\
\hline Mal funcionamento do sistema & 2,5 \\
\hline Erro humano & 3,2 \\
\hline Corrosão & 34,9 \\
\hline Interna & 1,9 \\
\hline Externa & 33,0 \\
\hline Causas Naturais & 5,0 \\
\hline Desmoronamento ou desabamento & 3,8 \\
\hline Inundação & 0,6 \\
\hline Outros & 0,6 \\
\hline Atividades Terciárias & 32,2 \\
\hline Dano direto acidental & 25,9 \\
\hline Dano direto intencional & 1,9 \\
\hline Dano incidental & 4,4 \\
\hline Total & 100,0 \\
\hline
\end{tabular}


Buscou-se realizar um levantamento dos acidentes envolvendo dutos no Brasil, junto a CETESB, Petrobrás, Greenpeace e à Rede Globo de Televisão, mas nenhum desses órgãos ou empresas forneceram nenhum tipo de informação.

O segundo fator foi a extensão da malha dutoviária instalada no Brasil, cuja distribuição é pouco conhecida pela sociedade.

Na Figura 1 observa-se a distribuição dos dutos que transportam hidrocarbonetos no Brasil. Nota-se um predomínio da distribuição próxima à zona litorânea, mas com dois alinhamentos recentes em direção ao interior, que deverão propiciar o desenvolvimento e a implantação de outros alinhamentos em futuro próximo.

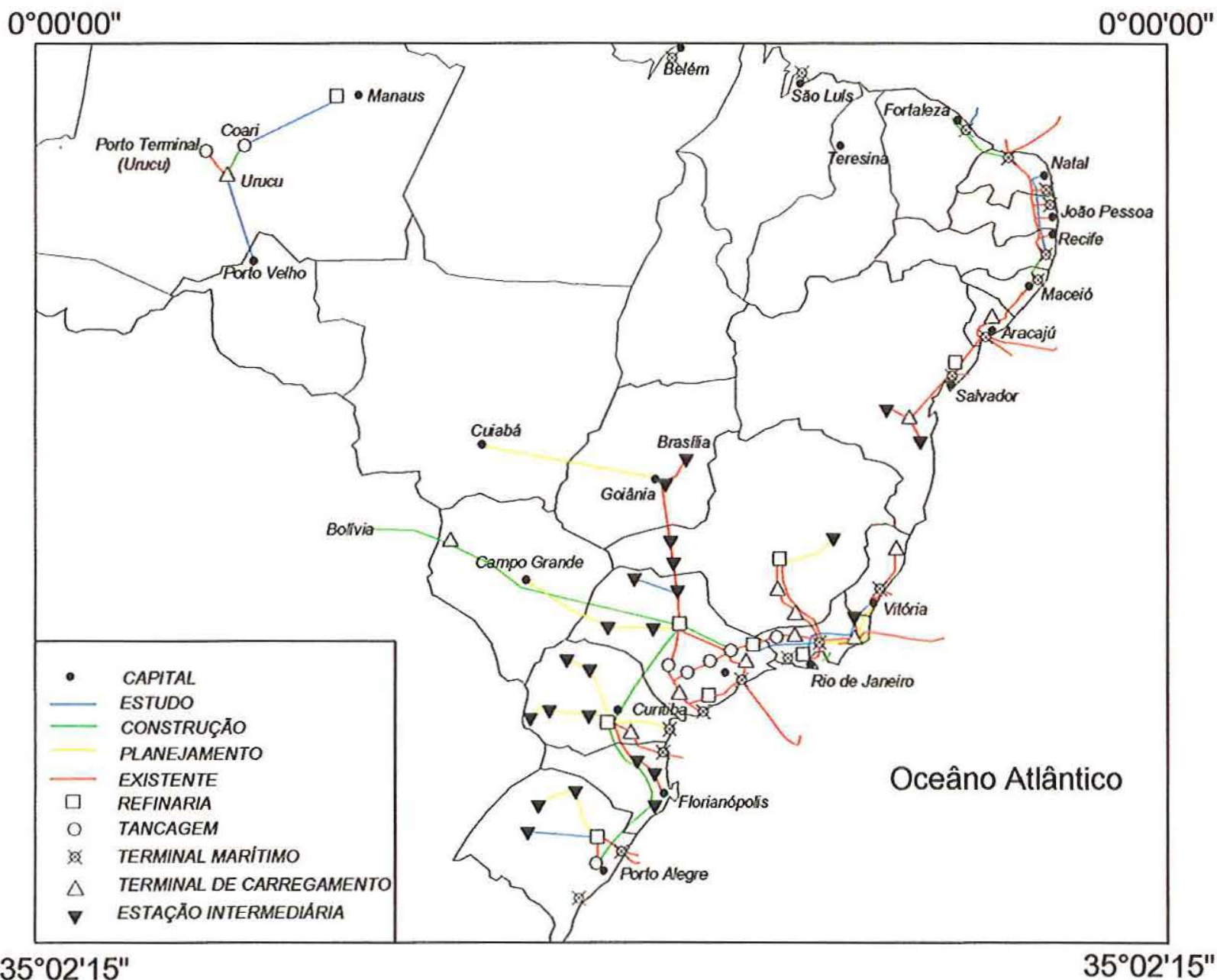

FIGURA 1: Distribuição dos dutos no Brasil (PETROBRÁS, 1997). 
Todos estes dutos têm por finalidade o transporte de combustíveis compostos de hidrocarbonetos para suprir a demanda de consumo no Brasil.

Considerando-se os dutos que estão em fase de construção e outros projetos que já estão sendo implantados no Brasil, a Petrobrás estima que a sua malha dutoviária passe de $12.000 \mathrm{Km}$, em 1.997, para $21.000 \mathrm{Km}$ até o ano 2.000 .

O terceiro fator é a possibilidade de contaminação de áreas de recarga, que pode formar uma extensão muito grande, comprometendo invariavelmente a qualidade das águas subterrâneas.

O trecho entre Porto Ferreira e Ribeirão Preto, foi escolhido por atravessar extensa área de recarga da Formação Botucatu e extensa área de basaltos fraturados pertencentes à Formação Serra Geral, além da intensa ocupação agrícola da região e do elevado número de bacias hidrográficas envolvidas caso ocorra rompimentos. A extensão da Formação Botucatu, bem como a infiltração de contaminantes através das fraturas podem servir como meios de penetração de contaminantes nas reservas subterrâneas de água. 


\subsection{INTRODUÇÃO}

A contaminação ou poluição do meio ambiente devido a emissão de produtos orgânicos envolve vários fatores físicos, químicos e biológicos. O levantamento bibliográfico apresentado neste capítulo abrange aspectos genéricos relacionados a estes fatores, tendo por objetivo o fornecimento de informações relevantes a execução da análise dos resultados apresentada no capítulo 5. Desta forma, consta desta revisão informações referentes a estrutura dos dutos, as características químicas dos hidrocarbonetos, a migração dos contaminantes orgânicos no meio físico e a modelagem computacional para simulação de fluxo de água subsuperficial e de transporte de contaminantes no meio físico. Informações mais específicas podem ser encontradas nas bibliografias apresentadas no capítulo 7 .

\subsection{CARACTERÍSTICAS GERAIS DOS DUTOS}

Os dutos podem ser constituídos de diversos materiais, tais como concreto amianto, argila vitrificada, concreto simples ou reforçado, fibrocimento, plástico, fibra de vidro, aço, ferro e outros, os quais vêm sendo utilizados em diversos países e em diversas formas e dimensões, dependendo da função a que se destinam. Cabe ressaltar que os materiais utilizados na fabricação dos dutos devem oferecer os níveis necessários de resistência à corrosão, impermeabilidade e integridade estrutural.

Os dutos podem ainda ser classificados como rígidos ou flexíveis, e apresentar diâmetros variáveis de acordo com o tipo de aplicação. Geralmente são utilizadas soldagens ou conectores mecânicos para obter uma perfeita e segura ligação entre os tubos. 


\subsubsection{Problemas mais comuns}

Os fatores que instabilizam os dutos e provocam acidentes podem estar relacionados às suas características mecânicas, aos aspectos de usinagem e de montagem, às interações entre o material que constitui o duto e o meio físico/material transportado.

Os acidentes podem ocorrer:

(1) na linha principal da tubulação;

(2) numa instalação auxiliar (exemplo: válvula).

As causas imediatas de rompimento da tubulação podem ser várias, a saber:

- corrosões pontuais;

- deformações;

- perda de sustentação devido a ocorrência de erosões internas (piping) e externas;

- falha na soldagem ou nos conectores;

- danos nos revestimentos do duto;

- vazamento nas válvulas;

- escavações manuais ou mecânicas que atingem os dutos;

- pressões exercidas por cargas externas e/ou internas, etc;

- abalos sísmicos;

- movimentos de massa;

- colapsividade.

Os fatores de risco que podem gerar uma dessas situações são muito diversificados e aleatórios, o que exige um planejamento cuidadoso e uma organização eficiente para atuar preventivamente sobre todos os fatores que apresentem problemas à integridade (resistência à corrosão, ao cisalhamento, a deformação) do duto.

Dentre os fatores que podem instabilizar os dutos, são aqui destacados dois deles: a corrosividade e os abalos sísmicos. A corrosividade é aqui discutida com a finalidade de expor os aspectos do meio físico que favorecem o aparecimento de corrosão em estruturas metálicas, uma vez que a atuação dos mesmos não é tão conhecida quanto os da erosão, escorregamento, etc. No item referente aos abalos sísmicos buscou-se explicar o porquê deste evento não ter sido considerado na análise dos resultados. 


\subsubsection{Corrosividade}

A corrosão é a principal causa de acidentes envolvendo dutos. No ano de 1998 ocorreram no Brasil pelo menos três acidentes deste tipo notificados pela imprensa, dois deles na Bahia e um em São José do Rio Preto.

Segundo ZUQUETTE (1987), os materiais inconsolidados ricos em sulfatos de magnésio e de sódio, principalmente os hidromórficos, podem produzir gás carbônico e ácidos minerais e orgânicos que atacam os concretos e os metais. Tais materiais, quando argilosos, podem conter sulfetos de ferro, que normalmente reagem com metais. Os materiais inconsolidados com $\mathrm{pH}<7$ e contendo sais dissolvidos, facilitam consideravelmente os processos de corrosão.

A profundidade e as variações do nível de água podem expor os tubos em contato com a zona de aeração por períodos intermitentes, o que facilita a oxidação e corrosão dos metais. Águas com pH $<7$ e concentração de sais maiores que $1.000 \mathrm{mg} / \mathrm{L}$, favorecem a corrosão. A corrosividade pode ser diferencial quando o duto estiver em contato com materiais que possuem características diferentes e sob excesso de umidade (ZUQUETTE, 1987).

A baixa resistividade elétrica auxilia no processo de corrosão e, segundo HUNTER et al., (1966, apud ZUQUETTE, 1987) as seguintes condições devem ser consideradas no caso de proteção contra a corrosão:

- Uso de anodo de $\mathrm{Zn}$ em obra com vida útil prevista de até 30 anos e para solos com resistividade maior que $1.500 \mathrm{ohms} / \mathrm{cc}$;

- Para solos com resistividade maior que $1.500 \mathrm{ohms} / \mathrm{cc}$, os anodos de $\mathrm{Mg}$ são recomendados;

Segundo BOUWER (1978), a corrosão pode ser causada pela presença de diferentes potenciais elétricos em contato com a obra, sendo que duas situações predominam:

- águas subsuperficiais com concentrações químicas variando com a profundidade, agindo em termos de grandes extensões, e

- quando houver pequenos poros ou quebras nos metais que permitam a entrada de água com taxa de oxigênio diferente do fluxo geral, haverá condições para a existência de potencial elétrico. 


\subsubsection{Abalos Sísmicos}

O trecho do OSBRA analisado neste trabalho, está situado na Zona Sismogênica de Ribeirão Preto. Segundo MIOTO (1993), o maior sismo desta Zona ocorreu em 1974, junto aos reservatórios de Porto Colômbia - Volta Grande (SP/MG). Sua magnitude alcançou 4,1 $\mathrm{mb}$, tendo ocorrido em local sem evidência de sismicidade natural e logo após o enchimento dos reservatórios. Os demais sismos foram inferiores a 3,0 mb, ou seja de baixa magnitude.

\subsection{PRODUTOS COMPOSTOS DE HIDROCARBONETOS}

\subsubsection{Petróleo bruto}

O petróleo é uma mistura complexa de compostos orgânicos, cuja maior parte são alcanos e hidrocarbonetos aromáticos, com pequenas quantidades de compostos como oxigênio, nitrogênio e enxofre. Em geral todos os subprodutos do petróleo são compostos quase que completamente por átomos de carbono e de hidrogênio, com menores proporções de nitrogênio e oxigênio (SOLOMONS, 1996). A menor molécula de hidrocarboneto é o metano $\left(\mathrm{CH}_{4}\right)$ e a maioria dos hidrocarbonetos comuns são de baixo peso molecular (ROBBINS et al., 1993).

\subsubsection{Derivados do petróleo}

\subsubsection{Gasolina}

A gasolina é uma mistura complexa de hidrocarbonetos hidrofóbicos relativamente voláteis. As características físico-químicas determinam o comportamento da gasolina e dos seus constituintes no ambiente. Os hidrocarbonetos típicos são os compostos alifáticos (alcanos, cicloalcanos, alquenos), aromáticos e aditivos, e são dominados por compostos com 4 a 12 átomos de carbono (SUTHERSAN, 1997). Muitos oxigenados, tais como álcoois e éteres são adicionados na gasolina para reduzir a poluição atmosférica e melhorar a octanagem do motor.

A Tabela 3 mostra a composição química de uma amostra de gasolina regular produzida nos Estados Unidos: 
TABELA 3: Composição química de uma gasolina comum (JOHNSON et al., 1990)

\begin{tabular}{|c|c|c|c|c|}
\hline Componente & $\begin{array}{l}\text { Fórmula } \\
\text { Química }\end{array}$ & $\begin{array}{c}\text { Massa } \\
\text { Molecular }\end{array}$ & $\begin{array}{l}\text { Fração } \\
\text { Mássica }\end{array}$ & $\begin{array}{l}\text { Fração } \\
\text { Molar }\end{array}$ \\
\hline Propano & $\mathrm{C}_{3} \mathrm{H}_{8}$ & 44,1 & 0,0001 & 0,0002 \\
\hline Isobutano & $\mathrm{C}_{4} \mathrm{H}_{10}$ & 58,1 & 0,0122 & 0,1999 \\
\hline n-butano & $\mathrm{C}_{4} \mathrm{H}_{10}$ & 58,1 & 0,0629 & 0,1031 \\
\hline trans-2-buteno & $\mathrm{C}_{4} \mathrm{H}_{8}$ & 56,1 & 0,0007 & 0,0012 \\
\hline cis-2-buteno & $\mathrm{C}_{4} \mathrm{H}_{8}$ & 56,1 & 0,0000 & 0,0000 \\
\hline 3-metil-1-buteno & $\mathrm{C}_{5} \mathrm{H}_{10}$ & 70,1 & 0,0006 & 0,0008 \\
\hline isopentano & $\mathrm{C}_{5} \mathrm{H}_{12}$ & 72,2 & 0,1049 & 0,1384 \\
\hline 1-pentano & $\mathrm{C}_{5} \mathrm{H}_{10}$ & 70,1 & 0,0000 & 0,0000 \\
\hline 2-metil-1-butano & $\mathrm{C}_{5} \mathrm{H}_{10}$ & 70,1 & 0,0000 & 0,0000 \\
\hline 2-metil-1,3-butadieno & $\mathrm{C}_{5} \mathrm{H}_{8}$ & 68,1 & 0,0000 & 0,0000 \\
\hline n-pentano & $\mathrm{C}_{5} \mathrm{H}_{12}$ & 72,2 & 0,0586 & 0,0773 \\
\hline trans-2-pentano & $\mathrm{C}_{5} \mathrm{H}_{10}$ & 70,1 & 0,0000 & 0,0000 \\
\hline 2-metil-2-buteno & $\mathrm{C}_{5} \mathrm{H}_{10}$ & 70,1 & 0,0044 & 0,0060 \\
\hline 3-metil-1,2-butadieno & $\mathrm{C}_{5} \mathrm{H}_{8}$ & 68,1 & 0,0000 & 0,0000 \\
\hline 3,3-dimetil-1-buteno & $\mathrm{C}_{6} \mathrm{H}_{12}$ & 84,2 & 0,0049 & 0,0055 \\
\hline ciclopentano & $\mathrm{C}_{5} \mathrm{H}_{10}$ & 70,1 & 0,0000 & 0,0000 \\
\hline 3-metil-1-penteno & $\mathrm{C}_{6} \mathrm{H}_{12}$ & 84,2 & 0,0000 & 0,0000 \\
\hline 2,3-dimetilbutano & $\mathrm{C}_{6} \mathrm{H} 14$ & 86,2 & 0,0730 & 0,0807 \\
\hline 2-metilpentano & $\mathrm{C}_{6} \mathrm{H} 14$ & 86,2 & 0,0273 & 0,0302 \\
\hline 3-metilpentano & $\mathrm{C}_{6} \mathrm{H}_{14}$ & 86,2 & 0,0000 & 0,0000 \\
\hline n-hexano & $\mathrm{C}_{6} \mathrm{H}_{14}$ & 86,2 & 0,0283 & 0,0313 \\
\hline metilciclopentano & $\mathrm{C}_{6} \mathrm{H}_{12}$ & 84,2 & 0,0000 & 0,0000 \\
\hline 2,2-dimetilpenttano & $\mathrm{C}_{7} \mathrm{H}_{16}$ & 100,2 & 0,0076 & 0,0093 \\
\hline benzeno & $\mathrm{C}_{6} \mathrm{H}_{6}$ & 78,1 & 0,0076 & 0,0093 \\
\hline ciclohexano & $\mathrm{C}_{6} \mathrm{H}_{12}$ & 84,2 & 0,0000 & 0,0000 \\
\hline 2,3-dimetilpentano & $\mathrm{C}_{7} \mathrm{H}_{16}$ & 100,2 & 0,0390 & 0,0371 \\
\hline 3-metilhexano & $\mathrm{C}_{7} \mathrm{H}_{16}$ & 100,2 & 0,0000 & 0,0000 \\
\hline 3-etilpentano & $\mathrm{C}_{7} \mathrm{H}_{16}$ & 100,2 & 0,0000 & 0,0000 \\
\hline 2,2,4-trimetilpentano & $\mathrm{C}_{8} \mathrm{H}_{18}$ & 114,2 & 0,0121 & 0,0101 \\
\hline n-heptano & $\mathrm{C}_{7} \mathrm{H}_{16}$ & 100,2 & 0,0063 & 0,0060 \\
\hline metilciclohexano & $\mathrm{C}_{7} \mathrm{H}_{14}$ & 98,2 & 0,0000 & 0,0000 \\
\hline 2,2-dimetilhexano & $\mathrm{C}_{8} \mathrm{H}_{18}$ & 114,2 & 0,0055 & 0,0046 \\
\hline
\end{tabular}




\begin{tabular}{|c|c|c|c|c|}
\hline tolueno & $\mathrm{C}_{7} \mathrm{H}_{8}$ & 92,1 & 0,0550 & 0,0568 \\
\hline 2,2,4-trimetilpentano & $\mathrm{C}_{8} \mathrm{H}_{18}$ & 114,2 & 0,0121 & 0,0101 \\
\hline 2-metilheptano & $\mathrm{C}_{8} \mathrm{H}_{18}$ & 114,2 & 0,0155 & 0,0129 \\
\hline 3-metilheptano & $\mathrm{C}_{8} \mathrm{H}_{18}$ & 114,2 & 0,0000 & 0,000 \\
\hline n-octano & $\mathrm{C}_{8} \mathrm{H}_{18}$ & 114,2 & 0,0013 & 0,0011 \\
\hline 2,4,4-trimetilhexano & $\mathrm{C}_{9} \mathrm{H}_{20}$ & 128,3 & 0,0087 & 0,0065 \\
\hline 2,2-dimetilheptano & $\mathrm{C}_{9} \mathrm{H}_{20}$ & 128,3 & 0,0000 & 0,0000 \\
\hline p-xileno & $\mathrm{C}_{8} \mathrm{H}_{10}$ & 106,2 & 0,0957 & 0,0858 \\
\hline m-xileno & $\mathrm{C}_{8} \mathrm{H}_{10}$ & 106,2 & 0,0000 & 0,0000 \\
\hline 3,3,4-trimetilhexano & $\mathrm{C}_{9} \mathrm{H}_{20}$ & 128,3 & 0,0281 & 0,0209 \\
\hline o-xileno & $\mathrm{C}_{8} \mathrm{H}_{10}$ & 106,2 & 0,0000 & 0,0000 \\
\hline 2,2,4-trimetilheptano & $\mathrm{C}_{10} \mathrm{H}_{22}$ & 142,3 & 0,0105 & 0,0070 \\
\hline 3,3,5-trimetilheptano & $\mathrm{C}_{10} \mathrm{H}_{22}$ & 142,3 & 0,0000 & 0,0000 \\
\hline n-propilbenzeno & $\mathrm{C}_{9} \mathrm{H}_{12}$ & 120,2 & 0,0841 & 0,0666 \\
\hline 2,3,4-trimetilheptano & $\mathrm{C}_{10} \mathrm{H}_{22}$ & 142,3 & 0,0000 & 0,0000 \\
\hline 1,3,5-trimetilbenzeno & $\mathrm{C}_{9} \mathrm{H}_{12}$ & 120,2 & 0,0411 & 0,0325 \\
\hline 1,2,4-trimetilbenzeno & $\mathrm{C}_{9} \mathrm{H}_{12}$ & 120,2 & 0,0213 & 0,0169 \\
\hline metilpropilbenzeno & $\mathrm{C}_{10} \mathrm{H}_{14}$ & 134,2 & 0,0351 & 0,0249 \\
\hline dimetiletilbenzeno & $\mathrm{C}_{10} \mathrm{H}_{14}$ & 134,2 & 0,0307 & 0,0218 \\
\hline 1,2,4,5-tetrametilbenzeno & $\mathrm{C}_{10} \mathrm{H}_{14}$ & 134,2 & 0,0133 & 0,0094 \\
\hline 1,2,3,4-tetrametilbenzeno & $\mathrm{C}_{10} \mathrm{H}_{14}$ & 134,2 & 0,0129 & 0,0091 \\
\hline 1,2,4-trimetil-5-etilbenzeno & $\mathrm{C}_{11} \mathrm{H}_{16}$ & 148,2 & 0,0405 & 0,0260 \\
\hline n-dodecano & $\mathrm{C}_{12} \mathrm{H}_{26}$ & 170,3 & 0,0230 & 0,0129 \\
\hline naftaleno & $\mathrm{C}_{10} \mathrm{H}_{8}$ & 128,2 & 0,0045 & 0,0033 \\
\hline n-hexilbenzeno & $\mathrm{C}_{12} \mathrm{H}_{20}$ & 162,3 & 0,0000 & 0,0000 \\
\hline metilnaftaleno & $\mathrm{C}_{11} \mathrm{H}_{10}$ & 142,2 & 0,0023 & 0,0015 \\
\hline Total & & & 0,9969 & 1,0000 \\
\hline
\end{tabular}

A gasolina comercializada no Brasil possui ainda em sua composição aditivos como o MTBE (metil terc-butil éter) ou o álcool etílico anidro, na ordem de $20 \%$, cuja função é reduzir a poluição atmosférica. Deve-se ressaltar que estes compostos são adicionados à gasolina apenas no momento em que esta é colocada nos caminhões tanque. A análise da contaminação do meio físico por gasolina decorrente do vazamento de dutos deve, portanto descartar os efeitos cosolventes destes componentes aditivos. 
A Tabela 4 mostra a composição média da gasolina comercializada no Brasil em 1996, originária da Refinaria do Planalto em Paulinía (SP). Deve-se atentar ao fato de que a composição específica do produto final é muito variável em função das características do petróleo de origem, do método de produção e dos processos de destilação.

TABELA 4: Composição média da gasolina (PETROBRÁS, 1996).

\begin{tabular}{|lc|}
\hline \multicolumn{1}{|c|}{ Hidrocarbonetos } & Peso \% \\
\hline Saturados & 8,08 \\
Naftaleno & 30,20 \\
Parafinas Iso & 15,63 \\
Parafinas Normais & \\
Não Saturados & \\
Naftaleno & 2,63 \\
Parafinas Iso & 2,32 \\
Parafinas Normais & 2,22 \\
Aromáticos & \\
& 18,35 \\
Oxigenados & \\
Metanol & \\
Etanol & \\
MTBE & 0,62 \\
Polinaftaleno & 0,59 \\
C 11 & 16,61 \\
\hline
\end{tabular}

\subsubsection{2. Óleos Brutos}

A maioria dos óleos brutos, não contém concentrações abundantes de hidrocarbonetos aromáticos, isto é, BTEX (benzeno, tolueno, etilbenzeno e xilenos), pois os mesmos são produzidos durante o processo de destilação e são associados aos produtos de petróleo refinados, por exemplo, gasolina, diesel e querosene (ROBBINS et al., 1993). 


\subsubsection{Diesel}

O diesel é composto principalmente por hidrocarbonetos de cadeias simples, não ramificadas. As diferenças mais importantes entre a gasolina e o diesel são o tamanho das cadeias, o número de carbono existentes na estrutura, o peso molecular, a pressão de vapor e a menor quantidade de hidrocarbonetos aromáticos (BTEX).

\subsubsection{Gases}

Os gases de petróleo, líquidos ou condensados, consistem principalmente de produtos de vapor de alta pressão, e que portanto podem ser mantidos na fase líquida apenas sob pressão. A maioria das moléculas encontradas no condensado são de baixo peso molecular, e correspondem aos hidrocarbonetos alifáticos.

A presença de contaminantes no meio ambiente pode atingir níveis de concentração acima do limite aceitável para consumo humano. Deve-se considerar a qualidade da água com relação ao uso a que se destina, por exemplo, para a maioria das finalidades industriais a água deve apresentar níveis de hidrocarbonetos compatíveis com os da água potável. A Agência de Proteção Ambiental dos Estados Unidos (USEPA), estabeleceu o nível máximo de contaminantes orgânicos para a água de consumo humano. Alguns desses limites estão apresentados na Tabela 5:

TABELA 5: Limites de concentração de contaminantes orgânicos em água potável (FETTER, 1993)

\begin{tabular}{|l|c|}
\hline \multicolumn{1}{|c|}{ Contaminante } & Limite $(\mu \mathrm{g} / \mathrm{L})$ \\
\hline Benzeno & Zero \\
1,2- Dicloroetano & Zero \\
Etilbenzeno & 700 \\
1,2,4- Triclorobenzeno & 9 \\
TCE & Zero \\
Tolueno & 1.000 \\
Xileno & 10,00 \\
\hline
\end{tabular}




\subsubsection{Propriedades dos compostos de hidrocarbonetos}

O comportamento dos produtos individuais e das misturas no ambiente é influenciado, em grande parte, por suas propriedades físicas e químicas, as quais governam a partição, o tipo de transporte e o destino destes contaminantes.

\subsubsection{Solubilidade}

A solubilidade de um composto químico em água é a medida da concentração deste composto que será dissolvida em água pura em uma determinada temperatura. Para compostos puros, a solubilidade em água é função do tipo de estrutura molecular e das características eletroquímicas. Para misturas de orgânicos como a gasolina, a solubilidade é função da fração molar de cada constituinte individual da mistura. A concentração de um composto individual em equilíbrio em água contendo uma mistura de hidrocarbonetos pode ser expressa de acordo com a seguinte equação:

$$
C_{i}^{*}=C_{i}^{0} X_{i} \gamma_{i}
$$

onde:

- $C_{i}^{*}=$ concentração de equilibrio do soluto para o componente $i$ na mistura;

- $C_{i}^{0}=$ concentração de equilibrio do soluto para o componente $i$ como um composto puro;

- $X_{i}=$ fração molar do composto $i$ em uma mistura;

$-\gamma_{i}=$ coeficiente de atividade do composto $i$ na mistura.

Quando idealizamos os compostos orgânicos misturados em água, reconhecemos que as moléculas orgânicas e as moléculas de água diferem entre si quanto a dois fatores principais:

(1) elas têm tamanhos e formas muito diferentes e;

(2) em geral as moléculas orgânicas são formadas por átomos com eletronegatividade comparáveis resultando em uma distribuição eletrônica regularmente espaçada. 
Essas diferenças entre o soluto e o solvente tem várias contribuições entálpicas e entrópicas, denominadas coeficiente de atividade do componente em água, $\gamma_{\mathrm{w}}$. A solubilidade de um soluto em água é, por vezes, definida como equivalente ao seu coeficiente de atividade em água (YALKOWSKY \& BANERJEE, 1992, apud SUTHERSAN, 1997).

$$
\log C_{w}=-\log \gamma_{w}
$$

onde:

- $C_{w}=$ solubilidade do composto em água;

$-\gamma_{w}=$ coeficiente de atividade do composto em água.

Sabe-se que a solubilidade dos compostos orgânicos, geralmente decresce com o aumento do peso molecular e pode ser influenciada pela dissolução, reatividade, degradação, temperatura, pressão e salinidade (DAHMANI et al., 1993). A presença de outros compostos orgânicos codissolvidos na água pode afetar a solubilidade total do produto orgânico de interesse (BARRETT et al., 1994).

Outra forma de estimar a solubilidade de um composto é através do coeficiente de partição octanol/água $\left(K_{o w}\right)$, que é uma constante de equilíbrio adimensional que caracteriza a partição de um soluto orgânico entre o octanol e a água. Quanto maior o valor deste coeficiente, maior a tendência do contaminante ser dissolvido em líquidos orgânicos do que em água (FETTER, 1993).

A solubilidade é uma propriedade muito importante pois afeta o transporte e o destino dos compostos no ambiente. Os compostos mais utilizados como indicadores da contaminação por gasolina são normalmente o benzeno, tolueno, etilbenzeno e xilenos (BTEX).

\subsubsection{Pressão de vapor}

A pressão de vapor de um líquido ou sólido é a pressão exercida por um vapor em equilíbrio com o líquido ou o sólido em uma temperatura específica. A pressão de vapor representa a tendência de um composto, presente no solo ou na água, sofrer volatilização e partição para a fase gasosa. Quanto maior a pressão de vapor, mais volátil é a substância. Segundo DOMENICO et al., (1990), a Lei de Raoult descreve a pressão parcial de um 
composto orgânico volátil, em equilibrio, na atmosfera para um composto ideal (como o benzeno):

$$
P_{\text {org }}=x_{\text {org }} P_{\text {org }}^{0}
$$

onde:

- $P_{\text {org }}=$ pressão parcial de vapor na fase gasosa;

$-x_{\text {org }}=$ fração molar do composto orgânico;

- $P_{\text {org }}^{0}=$ pressão de vapor de um composto orgânico puro.

A volatilização de solutos orgânicos dissolvidos na água é descrita pela lei de Henry. A constante de Henry $\left(K_{H}\right)$, geralmente expressa em atmosferas $\mathrm{m}^{3} / \mathrm{mol}$, é igual a $P^{0}$ em atmosferas dividido pela solubilidade do composto em água $\left(\mathrm{moles} / \mathrm{m}^{3}\right)$. Quanto maior o valor dessa constante, maior é a taxa de volatilização da substância. Assim, normalmente trata-se a volatilização de compostos puros (ex. benzeno) usando a lei de Raoult, e a volatilização de solutos (ex. benzeno dissolvido em água) usando a lei de Henry.

A pressão de vapor de compostos orgânicos pode diferir de muitos outros em ordem de magnitude. Essas variações, composto a composto, são causadas pelas diferentes interações moleculares. Os constituintes da gasolina (exemplo: benzeno, tolueno, etilbenzeno, e xilenos) e os solventes clorinatados e não clorinatados (exemplo: tricloroetileno, tetracloroetileno, acetona) têm pressões de vapor relativamente elevadas e são, portanto, relativamente voláteis.

\subsubsection{Densidade}

Segundo FETTER (1993), a densidade de um fluido é uma relação de sua massa por unidade de volume. Esta propriedade varia com as interações entre as substâncias, a estrutura molecular e o peso molecular. A principal razão de se conhecer a densidade de uma substância é determinar se a mesma flutuará sobre a água (densidade $<1.0 \mathrm{mg} / \mathrm{L}$ ) ou afundará sob a água (densidade $>1 \mathrm{mg} / \mathrm{L}$ ). No caso da gasolina, cuja densidade é da ordem de $0,72 \mathrm{mg} / \mathrm{L}$, a mistura se comportará como um líquido não aquoso mais leve que a água. 


\subsubsection{Viscosidade Dinâmica}

Viscosidade dinâmica é a medida de resistência de um fluido para escoar. Um aumento na temperatura tende a baixar a viscosidade e pode aumentar a mobilidade da gasolina no solo. A viscosidade dos produtos refinados de petróleo aumenta caso a mistura contenha compostos pesados.

A Tabela 6 mostra estas propriedades para alguns compostos orgânicos de interesse nos problemas de contaminação do meio ambiente.

TABELA 6: Propriedades químicas de alguns compostos orgânicos. (Modificado de SPITZ \& MORENO, 1996).

\begin{tabular}{|c|c|c|c|c|c|c|}
\hline Composto & $\begin{array}{c}\text { Densidade } \\
\left(\mathrm{g} / \mathrm{cm}^{3}\right)\end{array}$ & $\begin{array}{c}\text { Viscosidade } \\
\text { (cp) }\end{array}$ & $\begin{array}{l}\text { Solubilidade } \\
\text { (ppm) }\end{array}$ & $\begin{array}{c}\text { Log Kow } \\
\text { (I) }\end{array}$ & $\begin{array}{c}\text { Pressão de } \\
\text { Vapor } \\
(\mathrm{mmHg})\end{array}$ & $\begin{array}{c}\text { Coeficiente } \\
\text { de Henry } \\
\left.\text { (atm. } \mathrm{m}^{3} / \mathrm{mol}\right)\end{array}$ \\
\hline Benzeno & 0,879 & 0.6028 & 820,1750 & $1,95-2,13$ & 60,0 & $2,67-5,3 \mathrm{E}^{-3}$ \\
\hline Etilbenzeno & 0,866 & 0,678 & 140 & $3,15-3,24$ & 7 & $5,7-6,6 \mathrm{E}^{-3}$ \\
\hline Naftaleno & 1,326 & 0,45 & $16,70-20,20$ & 1,25 & 362 & $2-2,5 \mathrm{E}^{-4}$ \\
\hline $\begin{array}{l}\text { Tetracloroetileno } \\
\text { (PCE) }\end{array}$ & 1,6 & 1,93 & $150-200$ & & 14 & \\
\hline Tolueno & 0,867 & 0,552 & 470 & $2,69-2,89$ & 10 & $5,7 \mathrm{E}^{-3}$ \\
\hline $\begin{array}{l}\text { 1,1,1- Tricloroeta } \\
\text { no (TCA) }\end{array}$ & 1,35 & 0,903 & 4400,5497 & $2,17-2,51$ & 100 & $3,6 \mathrm{E}^{-4}, 92 \mathrm{E}^{-3}$ \\
\hline $\begin{array}{l}1,1,2-\text { Tricloroeta } \\
\text { no }\end{array}$ & 1,44 & 0,12 & 4500,1100 & $2,17-2,07$ & 19 & $1,2 \mathrm{E}^{-2}, 7,43 \mathrm{E}^{-4}$ \\
\hline
\end{tabular}

Log Kow = coeficiente de partição octanol/água.

\subsection{FORMAS DE TRANSPORTE DO PRODUTO EM MEIO POROSO}

O comportamento do contaminante no meio físico é influenciado pelo tipo de produto liberado, suas características físico-químicas e pelas características dos materiais sólidos que compõem o meio físico. Assim, dependendo do tipo de produto e das características do meio físico é que haverá diferentes possibilidades tanto de infiltração quanto de interação desses contaminantes com as partículas do solo ou mesmo com microorganismos, os quais muitas vezes atuam como um modo de atenuar essas substâncias. 


\subsubsection{Fluxo aquoso}

O fluxo aquoso ocorre quando o meio de transporte é a água e os produtos, sejam sólidos, líquidos ou gasosos, encontram-se dissolvidos na fase aquosa.

\subsubsection{Fluxo Não Aquoso - (Nonaqueous Phase Liquids - NAPL)}

O fluxo não aquoso ocorre quando os produtos não são solúveis em água, mas permanecem como uma fase separada, tendo os hidrocarbonetos como produtos imiscíveis mais comuns. O fluxo da fase líquida não aquosa (NAPL) é controlado por fatores diferentes daqueles que controlam o fluxo aquoso. Os NAPLs são conhecidos pela sua persistência em subsuperfície e pela capacidade em contaminar um volume de água relativamente grande, visto que valores da ordem de ppb afetam o uso da mesma. Os NAPLs podem ser divididos em outras duas subfases, a saber, a fase líquida não aquosa leve (Light Nonaqueous Phase Liquids - LNAPL) e a fase líquida não aquosa densa (Dense Nonaqueous Phase Liquids - DNAPL).

\subsubsection{Fase Líquida Não Aquosa Leve (Light Nonaqueous Phase Liquids - LNAPL)}

Se a densidade da fase líquida não aquosa for menor do que a da água $(<1 \mathrm{mg} / \mathrm{L})$, o líquido é classificado como uma fase líquida não aquosa leve (LNAPL). Os LNAPLs normalmente incluem acetona, gasolina, óleo aquecido, querosene e benzeno. A Tabela 7 mostra tipos de LNAPLs comuns, com suas respectivas densidades e solubilidades em água.

TABELA 7: Densidade e solubilidade dos LNAPLs (FETTER, 1994).

\begin{tabular}{|lll|}
\hline Composto & $\begin{array}{l}\text { Densidade } \\
(\mathbf{m g} / \mathbf{L})\end{array}$ & $\begin{array}{l}\text { Solubilidade } \\
(\mathbf{m g} / \mathrm{L} \text { água a 20 }\end{array}$ \\
\hline Benzeno $\mathrm{C})$ \\
Etil benzeno & 0,88 & 1780 \\
Tolueno & 0,87 & 152 \\
Metil etil cetona & 0,81 & 515 \\
Cloreto de vinila & 0,91 & $353\left(\mathrm{a} 10^{\circ} \mathrm{C}\right)$ \\
\hline
\end{tabular}




\subsubsection{Fase Líquida Não Aquosa Densa \\ (Dense Nonaqueous Phase Liquids - DNAPL).}

A fase líquida não aquosa que possui maior densidade do que a da água é classificada como uma fase líquida não aquosa densa (DNAPL). Hidrocarbonetos clorinatados, PCBs, antraceno, pireno, 1,1,1-TCE, e fenol são compostos químicos que têm densidades maiores do que $1 \mathrm{mg} / \mathrm{L}$. A maioria dos DNAPLs pertencem a classe dos halogenados e não halogenados semivoláteis e halogenados voláteis. Os DNAPLs são utilizados nas indústrias de conservação de madeira e de pesticidas, além das indústrias que se utilizam dos solventes e do carvão de hulha. Os solventes orgânicos são os principais contaminantes que contêm DNAPLs.

\subsection{COMPORTAMENTO DA FASE LÍQUIDA NÃO AQUOSA}

A fase líquida não aquosa em meio poroso pode deslocar o ar e a água presentes nos poros dos sólidos e assim atingir a zona saturada.

\subsubsection{Fatores do meio físico que afetam o transporte do NAPL}

A Figura 2A mostra o sistema bifásico que ocorre na zona não saturada e na zona saturada, quando todo o ar existente nos poros é substituído por água. Nota-se na Figura 2B o desenvolvimento de uma quarta fase representada pela presença da fase líquida não aquosa (NAPLs) em subsuperfície. Na zona saturada contaminada com NAPLs podem ocorrer três possíveis fases - sólidos, NAPL e água, enquanto na zona não saturada, a entrada de NAPL resulta na ocorrência de quatro fases, como mostra a Figura 2B. As fases que podem estar presentes em um aqüífero contaminado são:

- Fase gasosa: contaminantes presentes na fase vapor;

- Fase aquosa: uma parte dos contaminantes pode estar dissolvida na água, dependendo da sua solubilidade;

- Fase imiscível: os contaminantes estão presentes como uma fase imiscível;

- Fase sólida: os contaminantes podem estar adsorvidos na superfície dos sólidos. 
As quatro fases podem ou não estar presentes em subsuperfície. No caso de um derrame de NAPL em superfície, a infiltração ocorre primeiramente pela zona não saturada e posteriormente pela zona saturada. O NAPL na zona não saturada tende a cobrir os grãos com um filme ao redor dos poros. Este filme eventualmente se desenvolve ocupando todos os espaços dos poros, caso haja uma quantidade suficiente de NAPL. Isto ocorre porque, dos dois fluidos existentes na zona não saturada (ar e NAPL), o NAPL é o que apresenta maior atração aos sólidos do solo. Esta afinidade é denominada grau de molhabilidade, e refere-se a atração relativa de vários fluidos - ar, água ou NAPLs - com os sólidos do solo. O fluido que cobre o grão é chamado fluido molhante, o outro fluido é o não molhante.
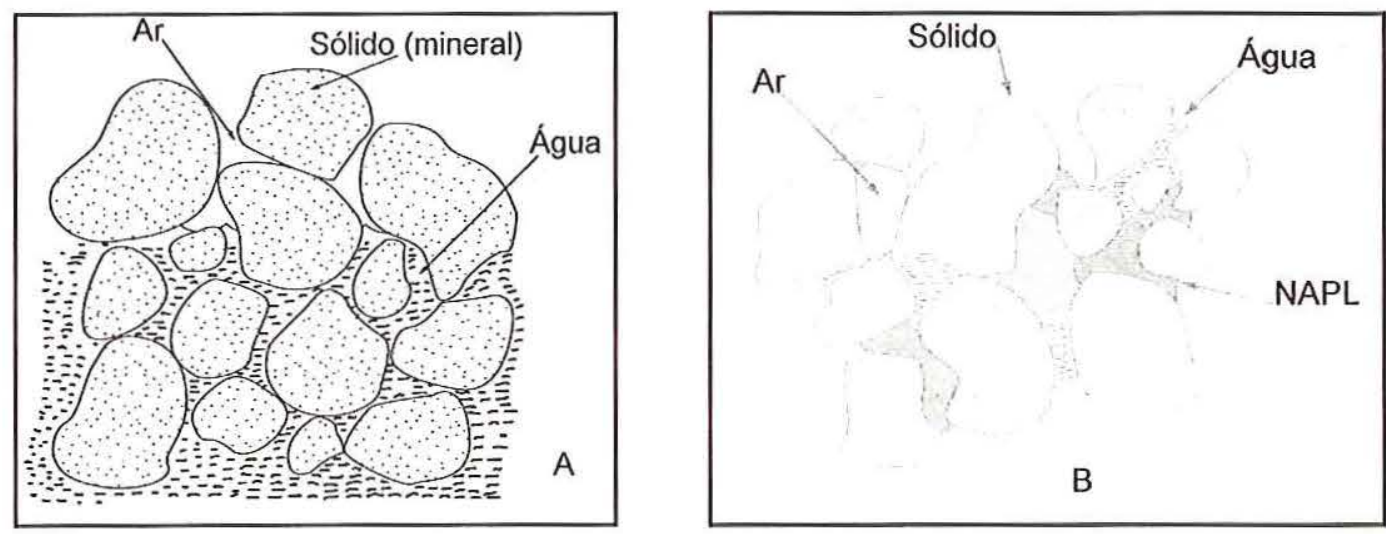

FIGURA 2: Esquema da ocorrência de diferentes fases em zona saturada e não saturada (A) e em zona não saturada (B) (EPA, 1989, 1991).

ALBERTSEN et al., (1986, apud HASAN, 1996) fazem a seguinte generalização quanto ao grau de molhabilidade relativa dos fluidos normalmente encontrados em soluções com a água:

- Sistema trifásico compreendendo sólidos inorgânicos (minerais), água e NAPL, a água é o fluido molhante e cobre o sólido. Se o ar está presente no lugar do NAPL, a água continua sendo o fluido molhante;

- Sistema trifásico compreendendo sólidos (minerais), NAPL e ar, o NAPL é o fluido molhante. No meio saturado, onde a água e o NAPL representam as duas fases fluidas, a água é considerada o fluido molhante; 
- Sistema trifásico compreendendo NAPL, água e sólidos orgânicos (húmus e turfa), o NAPL é considerado o fluido molhante, devido a afinidade química entre carbonos;

- Sistema de quatro fases compreendendo ar, NAPL, água e sólidos orgânicos, o NAPL é considerado o fluido molhante.

O NAPL comporta-se como um fluido não molhante na maioria dos meios saturados, por isso ele é armazenado no centro dos poros numa situação de saturação insular (Figura 3B). Entretanto, na zona não saturada o NAPL, comportando-se como um fluido molhante, espalha-se para os poros adjacentes. Este espalhamento resulta em uma redução no nível de concentração residual à sua situação anterior, significando que uma quantidade maior de NAPL é sorbida na zona não saturada do que na saturada.

Os fluidos molhantes tendem a ocupar os pequenos espaços porais (microporos) existentes na massa do solo, enquanto os fluidos não molhantes ocupam os grandes (macroporos). ALBERTSEN et al., (1986 apud HASAN, 1996) utilizaram o termo saturação residual pendular para se referir ao fluido que fica preso em uma parte estreita nos espaços de ligação entre os poros por forças de capilaridade (Figura 3A). A saturação insular tende a ocorrer na forma de bolhas isoladas no centro dos poros. A Figura 3B ilustra o NAPL em meio poroso em uma situação de saturação residual insular.

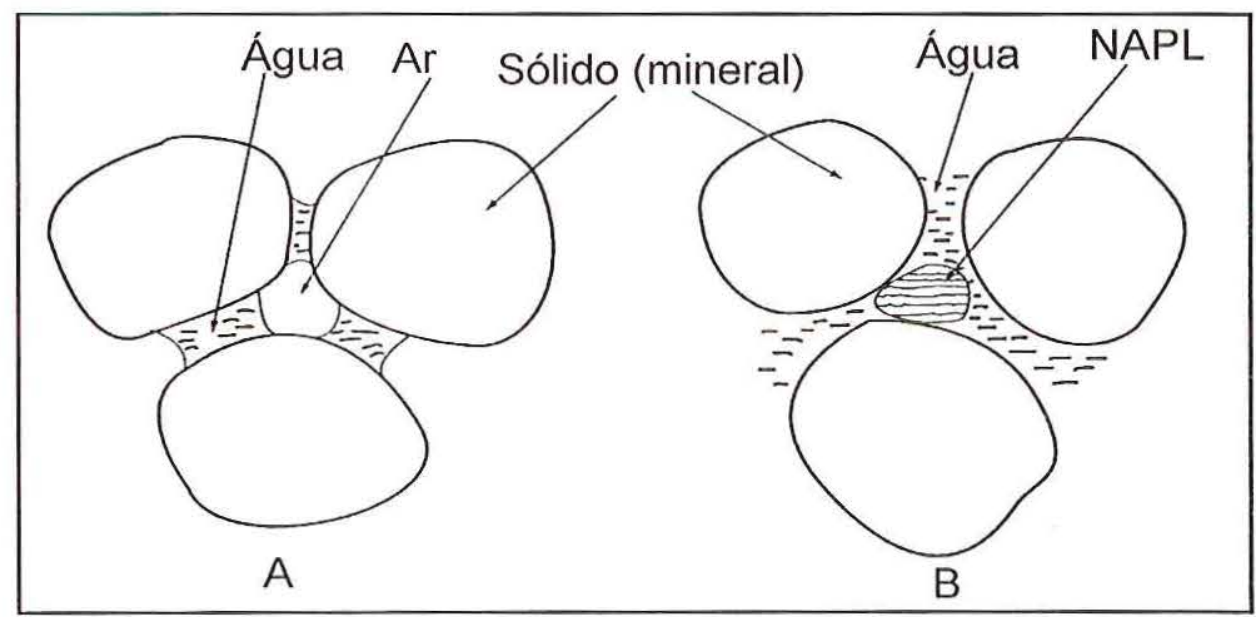

FIGURA 3: Saturação residual resultando em (A) saturação pendular e (B) saturação insular (EPA, 1991). 


\subsubsection{Grau de saturação}

Dependendo das porcentagens relativas do volume de poros ocupados por diferentes líquidos, o grau de saturação e o coeficiente de permeabilidade do meio poroso serão diferentes do que se os poros fossem ocupados por um único líquido. Tais diferenças influenciam significativamente a migração e a distribuição dos NAPLs na zona não saturada.

\section{Saturação residual}

No contexto da contaminação das águas subsuperficiais, a saturação residual tem sido descrita como o grau de saturação no qual o NAPL torna-se descontínuo e é imobilizado por forças de capilaridade (MERCER \& COHEN, 1990).

A relação entre pressão capilar e saturação residual em meios porosos, pode ser determinada experimentalmente em laboratório, obtendo-se curvas de pressão capilar X grau de saturação de acordo com o meio poroso e os líquidos ensaiados.

\subsubsection{Permeabilidade relativa}

Conforme discutido anteriormente, devido o grau de molhabilidade relativa da água e do NAPL, a água forma uma cobertura ao redor dos sólidos enquanto o NAPL ocupa a parte central dos poros. Em tais situações, diferente de um meio comum totalmente saturado por um fluido, nem o NAPL nem a água ocupa o volume total dos poros. Isto significa que o coeficiente de permeabilidade do meio poroso em relação a dois líquidos será diferente, menor do que seria em um meio ocupado por um único líquido. Esta redução no coeficiente de permeabilidade é denominada de coeficiente de permeabilidade relativa, e é definida como sendo a taxa de permeabilidade para um fluido a uma dada saturação em relação a esta permeabilidade para uma saturação igual a $100 \%$. A permeabilidade relativa situa-se em um intervalo de 1,0 para a completa saturação e 0 para o não saturado. Matematicamente isto pode ser expresso como:

$$
K_{r i}=\frac{K_{i}\left(S_{i}\right)}{K_{s i}}
$$


onde:

- $\mathrm{K}_{\mathrm{ri}}=$ coeficiente de permeabilidade relativa para o fluido $i$;

- $\mathrm{S}_{\mathrm{i}}=$ volume de poros ocupados pelo fluido $i$;

- $\mathrm{K}_{\mathrm{i}}\left(\mathrm{S}_{\mathrm{i}}\right)=$ coeficiente de permeabilidade de um meio para um fluido $i$ em uma saturação $\mathrm{S}_{\mathrm{i}}$;

- $\mathrm{K}_{\mathrm{si}}=$ coeficiente de permeabilidade do meio quando ele está completamente saturado com o fluido $i$.

Na presença de duas fases, NAPL e água, a permeabilidade zero, não necessariamente corresponde a uma saturação de $0 \%$. A Figura 4 mostra a permeabilidade de um meio poroso em relação à duas fases líquidas, NAPL e água. Quando o meio está saturado com NAPL, os valores da permeabilidade para o NAPL e para a água são de 1,0 e 0,0 respectivamente. $\mathrm{O}$ aumento contínuo do volume de água nos poros provoca a expulsão do NAPL devido a imiscibilidade destes dois líquidos, reduzindo a permeabilidade em relação ao NAPL para zero. O valor de permeabilidade zero para o NAPL não ocorre quando o volume de NAPL ocorre à uma saturação residual próxima de zero, correspondendo ao ponto $\mathrm{S}_{\mathrm{m}}$. Este ponto é denominado saturação residual do NAPL, ou seja a um volume de $20 \%$ de NAPL nos poros, o coeficiente de permeabilidade do meio poroso em relação ao NAPL é efetivamente zero, o que significa que nestas condições o NAPL encontra-se imobilizado por forças de capilaridade, ocorrendo apenas fluxo de água.

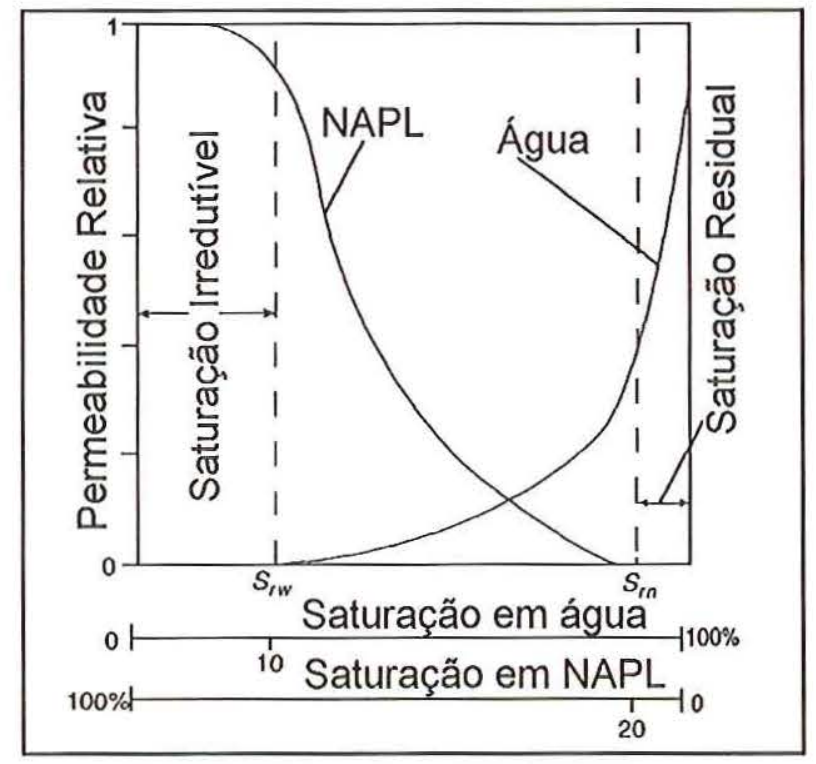

FIGURA 4: Curvas de permeabilidade relativa para a água e o NAPL (SCHWILLE, 1988) 
O coeficiente de permeabilidade relativa para a água é afetado do mesmo modo que para o NAPL: com o aumento da porcentagem de NAPL no volume de poros, a permeabilidade relativa para a água diminui, até atingir o ponto $\mathrm{S}_{\mathrm{nv}}$, quando o coeficiente de permeabilidade relativa para a água torna-se zero. $\mathrm{O}$ ponto $\mathrm{S}_{\mathrm{nw}}$ é denominado de saturação irredutível em água. SCHWILLE (1988), determinou que, em geral, os valores de saturação residual igual a zero para água e NAPL são respectivamente, $10 \%$ e $20 \%$. Isto significa que em um sistema com dois fluidos, para um grau de saturação de até $10 \%$ em água, ocorre apenas o fluxo de NAPL; para uma saturação de até $20 \%$ de NAPL, a água será o fluido móvel. O fluxo misto (água e NAPL) pode ocorrer entre estes dois limites de saturação.

Para efeito de análises laboratoriais, deve-se submeter o meio poroso e os fluidos de interesse a ensaios para determinar com maior precisão os pontos exatos nos quais ocorrem a saturação residual e a irredutível, para o meio poroso em questão.

\subsubsection{Retenção do Contaminante}

O volume de solo necessário para reter um determinado volume de hidrocarboneto líquido pode ser estimado (AMERICAN PETROLEUM INSTITUTE, 1972) utilizando-se a seguinte relação:

$$
V_{s}=\frac{0.2 V_{h c}}{P(R S)}
$$

onde:

- $\mathrm{V}_{\mathrm{s}}=$ volume de solo necessário para que todo o hidrocarboneto vazado esteja na condição de saturação residual;

$-\mathrm{V}_{\mathrm{hc}}=$ volume de hidrocarbonetos descarregados;

- $\mathrm{P}=$ porosidade do solo;

- RS = capacidade de saturação residual.

Estima-se a profundidade máxima de infiltração de hidrocarbonetos líquidos na zona não saturada, por aproximação, segundo DIETZ (1970) e VAN DAM (1967), pela expressão: 


$$
D=\frac{V_{s}}{A}
$$

onde:

- $D$ = profundidade máxima de infiltração do hidrocarboneto na zona não saturada;

- A = área de infiltração.

CONCAWE (1979) apresenta outra expressão:

$$
D=\frac{K V_{h c}}{A}
$$

onde:

- D = profundidade máxima de infiltração do hidrocarboneto na zona não saturada;

- $\mathrm{K}$ = constante baseada na capacidade de retenção do solo para óleo e de acordo com a viscosidade do óleo (Tabela 8);

$-\mathrm{V}_{\mathrm{hc}}=$ volume de hidrocarbonetos descarregados;

- A = área de infiltração.

TABELA 8: Valores típicos de K para os solos (DIETZ,1970 e CONCAWE, 1979)

\begin{tabular}{|l|ccc|}
\hline Tipo do Solo & Gasolina & Querosene & Gás/Óleo Leve \\
\hline Rocha a cascalho grosso & 400 & 200 & 100 \\
Cascalho à areia grossa & 250 & 125 & 62 \\
Areia grossa à média & 130 & 66 & 33 \\
Areia média à fina & 80 & 40 & 20 \\
Areia fina à síltica & 50 & 25 & 18 \\
\hline
\end{tabular}


Uma terceira fórmula é também apresentada por CONCAWE, (1979):

$$
D=\frac{1000 V_{h c}}{A R C}
$$

onde:

- D = profundidade máxima de infiltração do hidrocarboneto na zona não saturada;

$-\mathrm{V}_{\mathrm{hc}}=$ volume de hidrocarbonetos descarregados;

- A = área de infiltração;

- $\mathrm{R}$ = capacidade de retenção do solo (Tabela 9);

- $\mathrm{C}=$ fator de correção aproximada baseado na viscosidade do produto.

Segundo OLIVEIRA (1992), o fator de correção deve ser igual a 0,5 para produtos de baixa viscosidade, 0,1 para querosene e óleo diesel e 2,0 para óleos mais viscosos.

TABELA 9: Capacidade de retenção em óleo em solos não saturados (CONCAWE, 1979).

\begin{tabular}{|l|c|}
\hline \multicolumn{1}{|c|}{ Tipo de Solo } & Capacidade de Retenção em Óleo (R) - l/: $\mathbf{m}^{\mathbf{3}}$ \\
\hline Rocha, areia grossa & 5 \\
Cascalho, areia grossa & 8 \\
Areia grossa, areia média & 15 \\
Areia média, areia fina & 25 \\
Areia fina, silte & 40 \\
\hline
\end{tabular}

OLIVEIRA (1992) apresenta a seguinte equação para determinar o volume de produto retido nos poros:

$$
V_{R}=A d R
$$

onde:

$-V_{R}=$ volume de produto retido pelos poros;

- A = área atingida pelo vazamento;

- $d$ = distância vertical percorrida pelo produto até atingir o N.A.;

- $\mathrm{R}$ =capacidade de retenção do solo (Tabela 9). 


\subsubsection{Comportamento do LNAPL}

O transporte do LNAPL através das zonas não saturada e saturada depende, em grande parte, da quantidade de LNAPL liberada no meio. Um volume pequeno de LNAPL flui pela zona não saturada até atingir o estado de saturação residual, devido ao desenvolvimento de um sistema de quatro fases como resultado da entrada do LNAPL nesta zona, com a seguinte ordem de grau de molhabilidade: água $>$ LNAPL $>$ ar. A água de infiltração dissolve os componentes solúveis presentes no LNAPL, tais como o benzeno, o tolueno e o xileno, e os transporta até a zona saturada. Esses contaminantes dissolvidos formam uma pluma que se distribui por dispersão e advecção. Muitas das substâncias encontradas no LNAPL tendem a ser voláteis, assim, o gás sofre partição de modo que uma parte pode ficar no solo e outra no ar, e ser transportado por difusão molecular. Os voláteis movem-se primeiramente por meio da zona não saturada e finalmente entram na camada superficial do solo onde podem escapar para a atmosfera, serem adsorvidos pelas partículas do solo ou destruídos por biodegradação, ou ainda, dependendo das condições físicoquímicas, retornarem para a fase líquida. Esse processo de volatilização, transporte e liquefação provoca o transporte de contaminantes sobre áreas muito extensas.

Quando um grande volume de LNAPL é liberado, este se desloca no sentido da franja capilar próximo a zona saturada. No topo da franja capilar, onde a água satura um grande volume de poros, o material acumulado causa uma redução na permeabilidade relativa do LNAPL. Impedido de mover-se para baixo, o LNAPL tende a espalhar-se sobre o topo da franja capilar. O acumulo de um volume suficiente de LNAPL no topo da franja capilar, faz com que o mesmo comece a fluir na mesma direção da água subsuperficial (Figura 5). Devido a sua baixa densidade, os LNAPLs, flutuam próximo ao nível de água subsuperficial, na zona de capilaridade. Por causa destes mecanismos alguns produtos, tais como a gasolina, querosene, e alguns outros óleos são encontrados como produtos livres sobre o topo da franja capilar. 


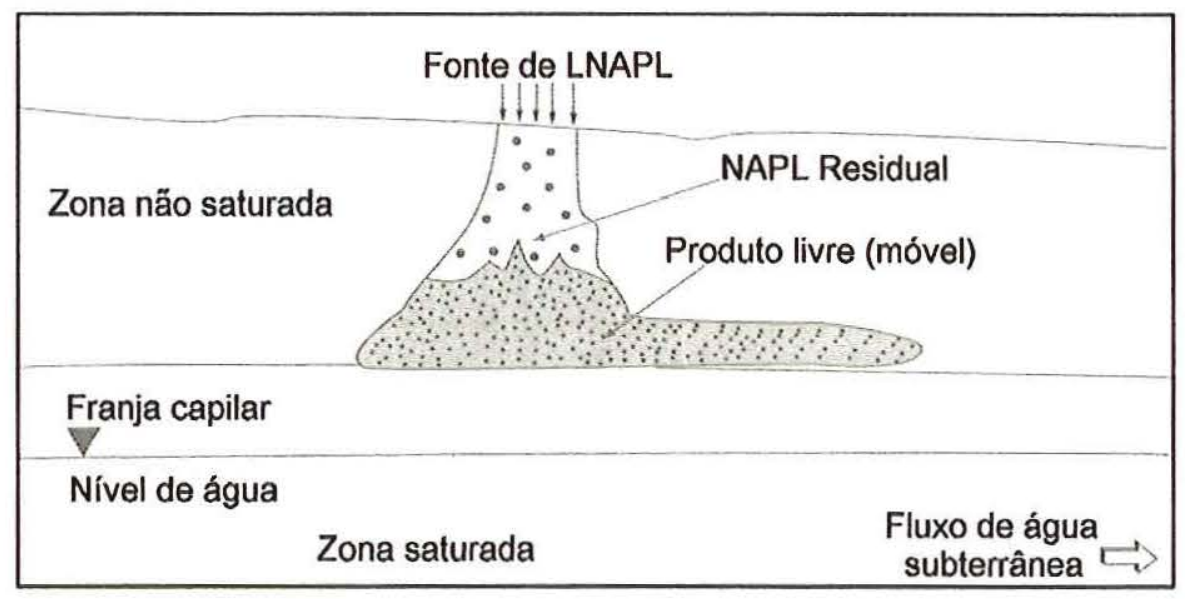

FIGURA 5: Transporte do LNAPL na zona não saturada e sobre a franja capilar (EPA, 1991).

Os grandes derrames geram um fornecimento contínuo de LNAPL na zona não saturada, favorecendo uma condutividade hidráulica progressiva e contínua, formando uma depressão de interface zona saturada-NAPL, onde os NAPLs se acumulam. No caso de remoção ou de esgotamento da fonte de fornecimento, os NAPLs presentes na zona não saturada continuam a migrar para níveis mais profundos, estacionando quando a concentração de NAPLs atinge o nível de saturação residual, e portanto não podem mais avançar. Caso contrário continuam a mover-se para baixo recarregando a depressão localizada sobre o nível de água subsuperficial (Figura 6A), produzindo um espalhamento lateral sobre a franja capilar.

Quando o suprimento de LNAPL cessa, o volume acumulado mantém o movimento descendente até atingir a saturação residual. A lixiviação do LNAPL existente nas partes superiores da zona não saturada reduz grande parte da frente de contaminação na interface LNAPL-zona saturada, fazendo com que a zona saturada retroceda (Figura 6B). Visto que o LNAPL próximo a zona saturada encontra-se no estado de saturação residual, o retrocesso da água subsuperficial consegue deslocar todo o LNAPL (este é relativamente imóvel devido a saturação residual). Parte da água subsuperficial que migra pode dissolver os materiais residuais, criando uma pluma de contaminação. A água de infiltração superficial também pode dissolver os LNAPLs residuais, criando assim um nível elevado de contaminação dos materiais superficiais. 
O bombeamento da água da zona saturada e as mudanças sazonais também provocam o rebaixamento do nível de água subsuperficial. Quando os LNAPLs estão localizados no topo do nível da zona saturada, a depressão associada causa também um novo abaixamento do LNAPL - frente de água subsuperficial. Quando a zona saturada eleva-se, devido a recarga ou ao estabelecimento das condições do estado de equilíbrio, parte do LNAPL é empurrado para cima, mas não totalmente, devido a saturação residual uma parte permanece nos poros abaixo do novo nível da zona saturada. Desta forma os LNAPLs podem ocupar uma grande espessura da zona saturada, provocando a contaminação de um grande volume de água.

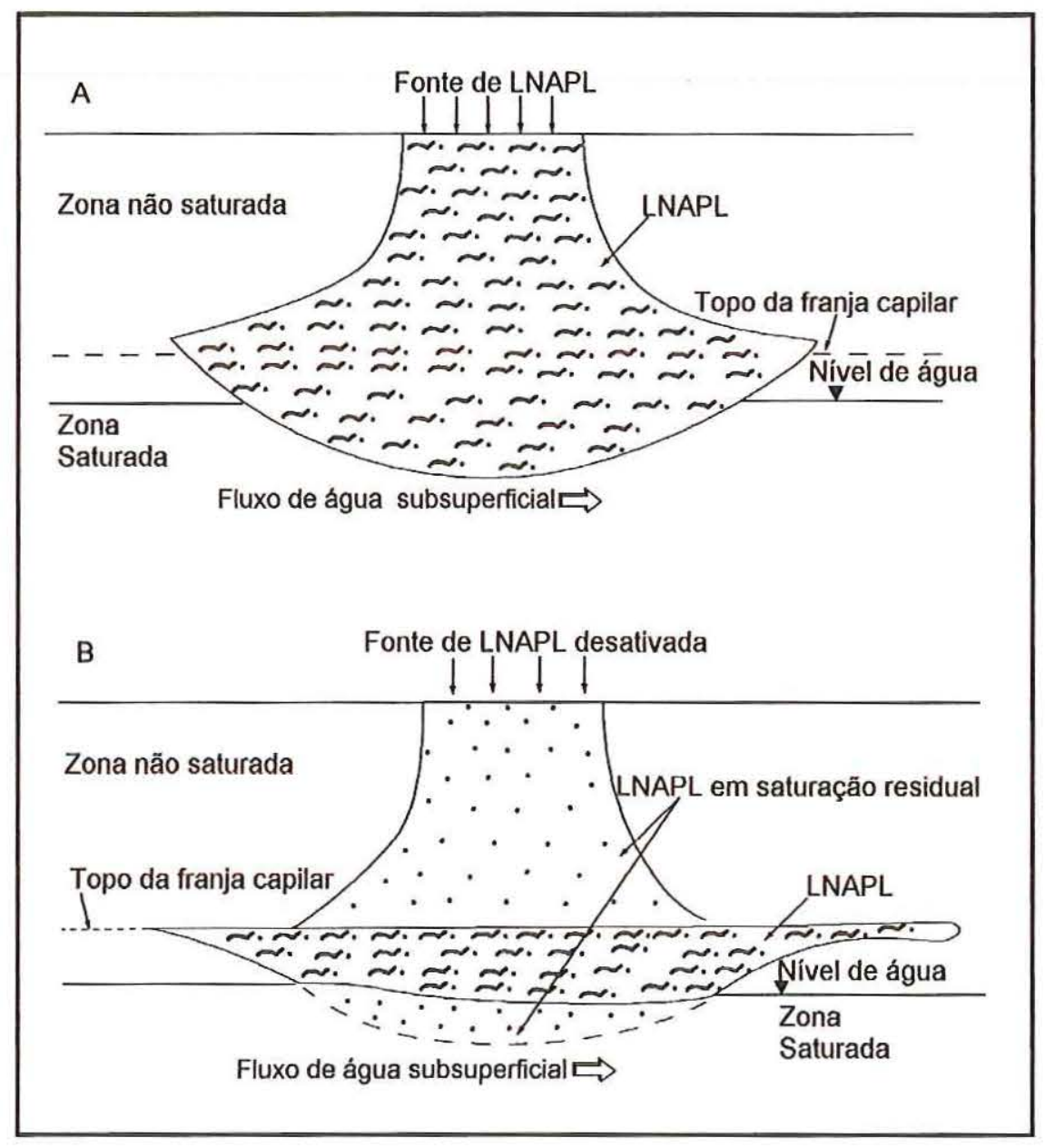

FIGURA 6: Depressão do nível de água subterrânea resultando em (A) grande frente de LNAPL, e (B) elevação do nível d'água (EPA, 1991). 
O espalhamento lateral da fase livre sobre o nível de água pode ser estimado (CONCAWE, 1979) através da equação:

$$
S=\left(\frac{1000}{F}\right)\left(V-\left[\frac{A d}{K}\right]\right)
$$

onde:

$\mathrm{S}=$ espalhamento máximo da fase livre $\left(\mathrm{m}^{2}\right)$;

$\mathrm{F}=$ espessura da fase livre $(\mathrm{mm})$;

$\mathrm{V}=$ volume de hidrocarbonetos infiltrantes $\left(\mathrm{m}^{3}\right)$;

$\mathrm{A}=$ área de infiltração $\left(\mathrm{m}^{2}\right)$;

$\mathrm{d}=$ profundidade da água subsuperficial (m);

$\mathrm{K}=$ constante dependente da capacidade de retenção do solo para óleo e de acordo com a viscosidade do óleo (Tabela 8).

\subsubsection{Comportamento do DNAPL}

A alta densidade, baixa viscosidade e solubilidade relativamente baixa faz com que o DNAPL seja altamente mobilizado em subsuperfície. A solubilidade baixa impossibilita a mistura do DNAPL com a água, gerando com isso duas fases. A combinação da densidade alta e da baixa viscosidade faz com que o DNAPL infiltre até atingir a zona saturada através do deslocamento da água. Fisicamente, isto resulta no desenvolvimento de forças instabilizantes e a ocorrência de uma franja viscosa (KUEPER \& FRIND, 1988). O transporte do DNAPL, assim como do LNAPL, é função do volume derramado.

O volume de DNAPL que percola em direção a zona saturada está diretamente relacionado à saturação residual, sendo que parte pode sofrer partição para a fase vapor denso que infiltrará até a zona de capilaridade (topo da zona saturada), a partir da qual poderá migrar dissolvida em água por uma grande extensão. A Figura 7 mostra um esquema representativo do processo descrito. 


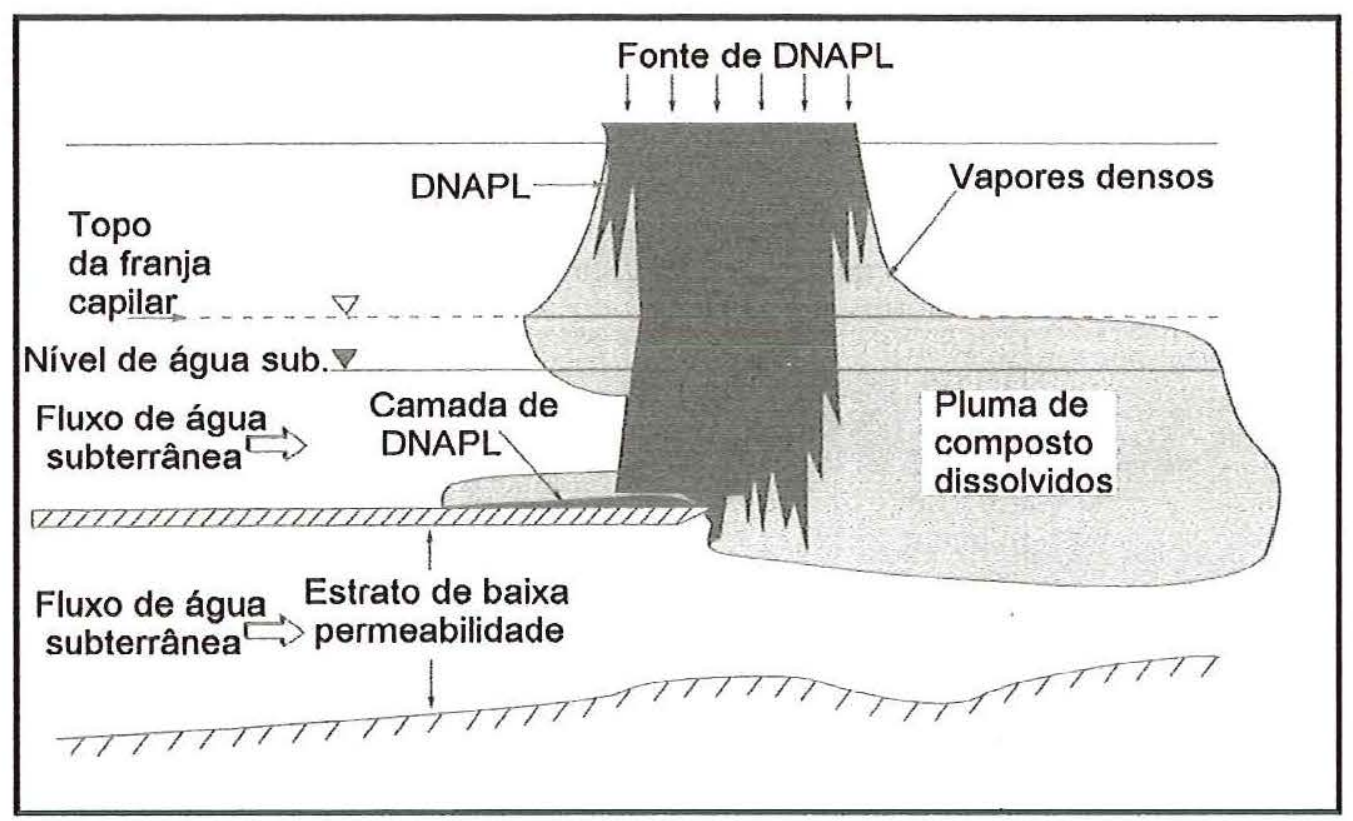

FIGURA 7: Partição do DNAPL na fase de vapores densos e de compostos dissolvidos (EPA, 1991).

Volumes elevados de DNAPL, muito superiores ao nível de saturação residual, infiltram atravessando a franja capilar atingindo a zona saturada. Uma vez atingida esta zona, o DNAPL continua movendo-se até atingir a condição de saturação residual, que representa um sistema trifásico constituído de DNAPL, água e sólidos. Os componentes do DNAPL solúveis em água constituem a fase que migra, enquanto a parte relativa a saturação residual e aos componentes do DNAPL adsorvidos nos sólidos representam as fases sorbidas e sem movimento. O principal mecanismo de transporte durante o estágio de saturação residual é a solubilização dos componentes solúveis do DNAPL em água. A água que percola pela zona contaminada e transporta o DNAPL dissolvido, cria uma frente de contaminą̧ão que pode atingir grandes extensões.

A presença de camadas de baixa permeabilidade ou camadas descontínuas, na forma de pacotes de granulometria fina, promove o acúmulo do DNAPL infiltrante no topo das mesmas. A migração lateral do DNAPL sobre estas camadas impermeáveis continua até que:

(1) a saturação residual seja alcançada; 
(2) o DNAPL encontre uma descontinuidade geológica ou outros locais situados abaixo da camada impermeável, onde o DNAPL se acumula formando um grande reservatório.

Sob ambas as condições, os componentes solúveis presentes no DNAPL sofrem partição na água subsuperficial. O DNAPL dissolvido pode ser transportado verticalmente atravessando o meio.

A presença de fraturas em materiais impermeáveis, tais como folhelhos, argilitos e rochas cristalinas, que ocorrerem abaixo do nível de zona saturada ou como camadas impermeáveis confinantes (Figura 8), também podem condicionar caminhos preferenciais para o transporte do DNAPL.

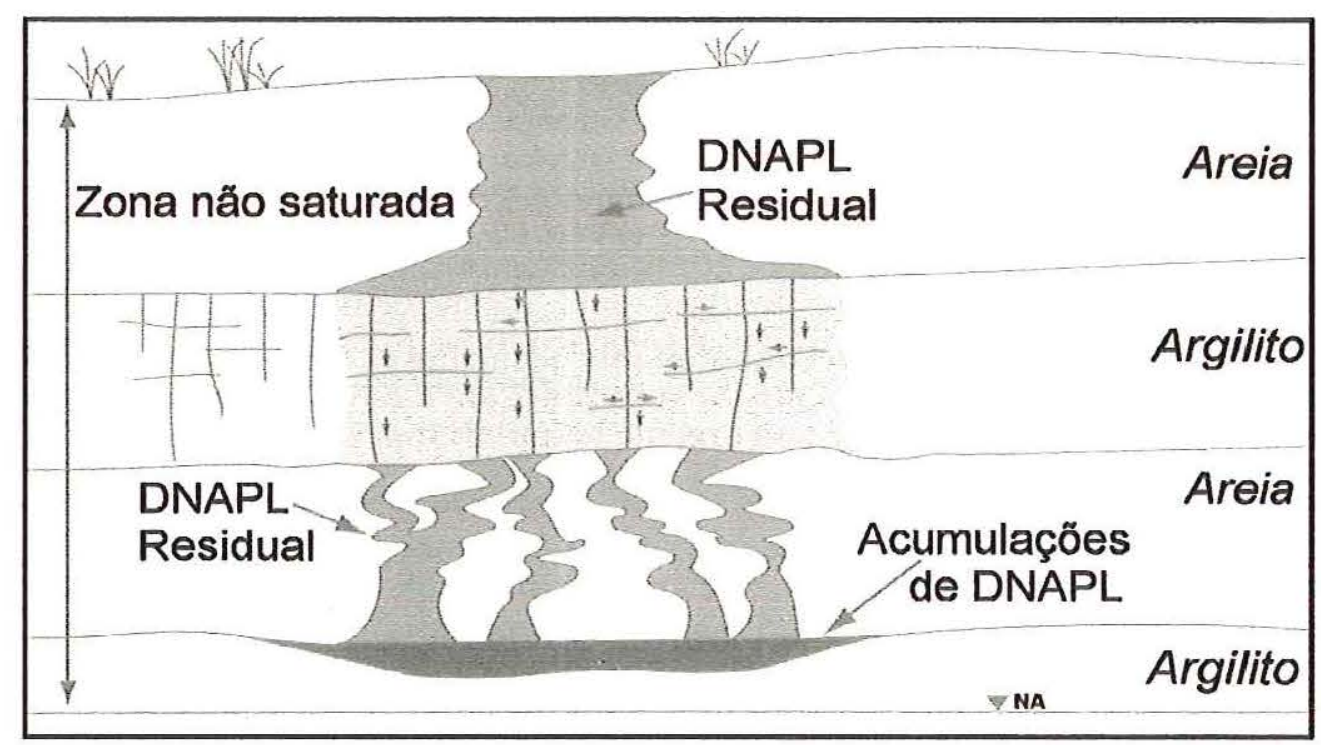

FIGURA 8: Percolação do DNAPL através de fraturas em material impermeável (EPA, 1991).

\subsection{TRANSPORTE EM FASE AQUOSA}

Embora os contaminantes orgânicos voláteis possam entrar em subsuperfície como uma fase imiscível, na maioria dos casos eles alcançam áreas ambientalmente sensíveis, como poços ou zonas de descarga de água subsuperficial, como constituintes dissolvidos da 
fase aquosa. O tempo necessário para os contaminantes partirem da área fonte, e a concentração dos contaminantes dissolvidos que atingem a área de interesse depende de uma série de processos físicos, químicos e bioquímicos, os quais influenciam as interações entre o material do aqüífero e as espécies dissolvidas. Considerando apenas as espécies reativas dissolvidas, os processos químicos e bioquímicos de maior importância incluem sorção, biodegradação e decaimento radioativo. Considerando apenas os materiais geológicos saturados, a advecção e a dispersão são geralmente considerados os principais processos de transporte.

Esses processos são brevemente discutidos a seguir. Para efeito de cálculo dos processos de transporte no meio físico, baseando-se em análises laboratoriais envolvendo NAPL, deve-se buscar outras equações nas bibliografias referidas no capítulo 8 .

\subsubsection{Advecção}

O transporte advectivo refere-se à migração de solutos como o resultado da movimentação da água subsuperficial na qual estão dissolvidos. Durante a evolução da maioria das plumas, a advecção é o mecanismo de transporte mais importante. A velocidade média do transporte advectivo pode ser obtida através da lei de Darcy:

$$
v_{x}=\frac{K}{n_{e}} \frac{\partial h}{\partial l}
$$

onde:

- $v_{x}=$ velocidade linear média $(\mathrm{L} / \mathrm{T})$;

- $K=$ condutividade hidráulica $(\mathrm{L} / \mathrm{T})$;

$-n_{e}=$ porosidade efetiva;

$-\frac{\partial h}{\partial l}=$ gradiente hidráulico.

O fluxo advectivo torna-se mais complexo quando a densidade e/ou a viscosidade da água muda com a concentração do soluto. Solutos com densidade elevada, em comparação com a água, introduzem um componente vertical de movimento de fluxo. Dependendo da extensão da contaminação, o comportamento da migração pode mudar 
drasticamente permitindo que os contaminantes migrem contra a direção natural do fluxo de água subsuperficial. $\mathrm{O}$ efeito das heterogeneidades do aqüífero sobre o fluxo aumenta de acordo com a densidade do fluxo da água subsuperficial (SPITZ \& MORENO, 1996).

No caso de contaminantes orgânicos, a condutividade hidráulica depende do grau de saturação ou da umidade volumétrica, definida como volume de água em relação ao volume de vazios do aqüífero.

\subsubsection{Dispersão Hidrodinâmica}

A dispersão hidrodinâmica engloba dois processos que favorecem o espalhamento do contaminante durante o transporte, a dispersão mecânica e a difusão molecular. SCHEIDDEGGER (1954) desenvolveu um modelo estatístico e introduziu uma constante de dispersão, a qual ele chamou de dispersividade média:

$$
D=\alpha v
$$

onde:

- $\mathrm{D}=$ coeficiente de dispersão $\left(\mathrm{L}^{2} / \mathrm{T}\right)$;

- $\alpha=$ dispersividade (L), uma propriedade do material poroso;

$-\mathrm{v}=$ velocidade linear média $(\mathrm{L} / \mathrm{T})$.

A dispersividade pode ser visualizada de acordo com as escalas e com as diferentes ordens de heterogeneidades do aqǘfero. A difusão molecular é definida como sendo a transferência de espécies químicas da região de maior concentração para a região de menor concentração, e tem importante papel na transferência de massa de zonas de baixa permeabilidade e de DNAPLs residuais para a fase aquosa. A dispersão, por sua vez, representa o espalhamento dispersivo devido, exclusivamente, às heterogeneidades do aqüífero.

Segundo GILLHAM \& RAO (1994) a forma mais utilizada de expressar a dispersão hidrodinâmica é:

$$
D=D_{o} \tau+\alpha V
$$


onde:

- $\mathrm{D}_{\mathrm{o}}=$ coeficiente de difusão $\left(\mathrm{L}^{2} / \mathrm{T}\right)$ do soluto em solução livre;

$-\tau=$ tortuosidade do meio (adimensional);

Mais freqüentemente a dispersão é um efeito indesejável devido ao espalhamento rápido dos contaminantes, aumentando o volume de água subsuperficial contaminada. A dispersão é sobreposta a velocidade média de transporte, e também transporta os contaminantes nas zonas que não participam diretamente da evolução da pluma advectiva. $\mathrm{O}$ espalhamento dispersivo conduzirá a um aumento na uniformidade da pluma com a distância.

Maiores detalhes sobre a transferência de massa de contaminantes orgânicos podem ser encontrados em SCHWARZENBACH et al., (1993).

\subsection{MECANISMOS DE ATENUAÇÃO DOS PRODUTOS DERIVADOS DO PETRÓLEO}

\subsubsection{Sorção}

Os processos de sorção podem retardar o espalhamento dos contaminantes durante o transporte dos mesmos. Sorção é um termo que se refere aos processos de absorção e de adsorção dos contaminantes presentes nas zonas saturada e não saturada.

Acredita-se que, no caso de contaminantes orgânicos, a adsorção seja o mecanismo mais efetivo, uma vez que a absorção seria dificultada em função do grande tamanho das moléculas orgânicas.

\subsubsection{Adsorção de hidrocarbonetos}

O termo adsorção descreve os processos nos quais as moléculas, ou íons, contidos na fase líquida ou gasosa tendem a se fixar sobre a superfície dos sólidos ou em sua estrutura. Nos solos e rochas estes processos ocorrem quando moléculas de gás, produtos da fase líquida livre, ou dos contaminantes dissolvidos em água são fixados à superfície de uma partícula individual do solo ou em partículas de matéria orgânica. 
As reações de adsorção do LNAPL e dos componentes orgânicos dissolvidos quase sempre são reações de equilíbrio químico reversíveis, assim, quando as condições de concentração mudam, as partículas podem adsorver mais moléculas orgânicas ou liberá-las.

Sendo a adsorção um fenômeno de superfície, sua atividade é uma função direta da área de superfície da partícula, bem como das forças elétricas ativas sobre essa superfície. A maioria dos componentes químicos do petróleo são não iônicos e por isso associam-se mais rapidamente com elementos orgânicos do que com as partículas minerais do solo. Uma pequena porcentagem de carbono orgânico pode ter uma capacidade de adsorção muito maior do que todos os componentes minerais.

A adsorção é, portanto, especialmente importante em materiais que contenham uma grande porcentagem de matéria orgânica (turfas, camadas de lagos antigos sedimentados, etc) pois são capazes de reter uma massa significativa de produtos. A maioria dos solos e rochas, entretanto, contêm menos que $1 \%$ de carbono e assim, a taxa de adsorção é sempre pequena.

A adsorção, para concentrações relativamente baixas de compostos hidrofóbicos (isto é, menores do que metade da sua solubilidade, ou menores do que $10^{-5}$ Molar), podem ser descritas pela seguinte equação (BARRETT et al., 1994; YONG et al., 1992; CLEARY, 1991):

$$
C_{s}=K_{d} C_{a}
$$

onde:

- $\mathrm{C}_{\mathrm{s}}=$ concentração do contaminante adsorvida sobre o sólido;

- $\mathrm{K}_{\mathrm{d}}=$ coeficiente de distribuição da adsorção;

$-\mathrm{C}_{\mathrm{a}}=$ concentração do contaminante dissolvido na fase aquosa.

Estudos laboratoriais têm demonstrado que pode-se fazer uma aproximação de $K_{d}$ baseando-se em fatores como conteúdo em carbono orgânico no solo e o coeficiente de partição octanol-água $\left(K_{\text {ow }}\right)$ do composto.

Segundo CLEARY (1991), $K_{o w}$ é determinado para uma mistura de octanol e água e um dado composto químico. Quanto maior o $K_{\text {ow }}$, mais elevada é a concentração do 
composto químico no octanol se comparada com a sua concentração em água. Esta taxa é utilizada para avaliar o comportamento de partição dos compostos entre solos contendo matéria orgânica e água. Quando um poluente é adsorvido no solo, ele pode ser liberado apenas quando o equilíbrio entre o contaminante e a água (ou ar) for interrompido.

BARRETT et al., (1994) consideram que a adsorção pode ser relacionada da seguinte forma:

$$
K_{d}=f_{o c} \cdot K_{o c}
$$

onde:

- $\mathrm{f}_{\text {oc }}=$ fração de carbono orgânico contida na fase sólida;

- $\mathrm{K}_{\mathrm{oc}}=$ coeficiente de distribuição do contaminante no carbono orgânico, que é uma função da solubilidade do contaminante.

Esta equação tem sido considerada válida quando o $f_{o c}$ for maior do que $0.1 \%$, pois abaixo deste nível, a partição ocorre preferencialmente pela adsorção do composto químico sobre a superfície do mineral do que sobre o carbono orgânico presente (BARRETT et al., 1994; YONG et al., 1992).

É interessante estender o conceito de sorção hidrofóbica para compostos mais polares e menos hidrofóbicos (hidrofílicos), por exemplo o metanol. Tais compostos possuem alta solubilidade em água e valores relativamente baixos de $\log K_{\text {ow }}(-0.66$ para o metanol, por exemplo). Em oposição aos compostos apolares, estes sofrem partição (preferencialmente) para a fase aquosa com menor afinidade aos compostos orgânicos. KARICKHOFF (1985, apud DOMENICO \& SCHWARTZ, 1990), recomenda que o modelo de sorção hidrofóbica deve ser utilizado apenas para compostos com solubilidades menores que $10^{-3} \mathrm{M}$.

CHAGAS et al., (1998), analisaram a interação entre um solo arenoso laterítico e os petroquímicos óleo diesel e gasolina. Os autores concluíram que tanto o diesel quanto a gasolina possuem compostos capazes de interagir com as superfícies minerais, favorecendo a sua retenção. Esta interação, no entanto, não segue um padrão definido quanto à uma série de fatores dentre os quais cita-se o grau de hidratação das superfícies, o teor e a distribuição dos sesquióxidos de ferro e da matéria orgânica, bem como à organização microestrutural do solo. 


\subsubsection{Bioremediação}

A bioremediação é um processo que transforma os contaminantes orgânicos em compostos a partir de microorganismos. É considerada como uma estratégia importante para otimizar a redução da concentração de contaminantes a níveis baixos (NORRIS, 1994).

Para que os processos de bioremediação do solo e da água subsuperficial in-situ sejam desenvolvidos é fundamental a presença de:

- nitrogênio e fósforo como nutrientes essenciais para o desenvolvimento dos microorganismos;

- um elétron receptor, geralmente oxigênio.

Segundo DOMENICO \& SCHWARTZ (1990) um grande número de meiasreações envolvem a oxidação de compostos orgânicos transformando-os em formas inorgânicas simples tais como $\mathrm{CO}_{2}$ e $\mathrm{H}_{2} \mathrm{O}$.

$$
\frac{1}{4} \mathrm{CH}_{2} \mathrm{O}+\frac{1}{4} \mathrm{O}_{2}(g)=\frac{1}{4} \mathrm{CO}_{2}(g)+\frac{1}{4} \mathrm{H}_{2} \mathrm{O}
$$

A reação de biotransformação consiste, portanto, na oxidação de um composto orgânico por um elétron receptor tal como $\mathrm{O}_{2}, \mathrm{NO}_{3}{ }^{-}, \mathrm{SO}_{4}{ }^{+}$, ou $\mathrm{CO}_{2}$ numa reação cuja proporção é controlada por microorganismos. Os contaminantes são hidrocarbonetos de petróleo tais como a gasolina, óleo bruto, óleo diesel, resíduos de refinaria, resíduos de óleo lubrificante, e óleo mineral (LEE et al., 1987, apud DOMENICO \& SCHWARTZ, 1990). Os constituintes monoaromáticos e alifáticos nesses hidrocarbonetos são completamente degradados em reações aeróbicas similares a que ocorre com o benzeno:

$$
\mathrm{C}_{6} \mathrm{H}_{6}+\frac{15}{2} \mathrm{O}_{2} \rightarrow 6 \mathrm{CO}_{2}+3 \mathrm{H}_{2} \mathrm{O}
$$

A utilização de elétrons receptores é uma boa alternativa para superar a deficiência no suprimento de oxigênio necessário nos processos aeróbicos. O nitrato, o sulfato e o dióxido de carbono são as melhores alternativas por serem mais solúveis em água, baratos e atóxicos aos microorganismos. 
NORRIS (1994) afirma que os hidrocarbonetos são considerados uma classe biodegradável. Os membros solúveis leves são, geralmente, biodegradados mais rapidamente, a baixos níveis residuais do que os membros menos solúveis, mais pesados. Portanto, os compostos monoaromáticos tais como BTEX são mais rapidamente degradados do que os compostos com anéis duplos tais como o naftaleno, que por sua vez são mais facilmente degradados do que os compostos aromáticos formados pela junção de três, quatro ou cinco anéis (poliaromáticos).

Alguns compostos são transformados somente sob condições aeróbicas, enquanto outros necessitam de condições fortemente redutoras e outros ainda são transformados nos dois ambientes, anaérobicos e aeróbicos. Em ambientes redutores, alguns contaminantes são reduzidos por processos biológicos conhecidos como deshalogenação redutiva. Em tais reações, o composto halogenado torna-se o elétron receptor. Neste processo, o halogênio é removido e substituído por um átomo de hidrogênio.

A Figura 9 mostra uma situação hipotética na qual tenha ocorrido um pequeno derrame de gasolina, a partir de um tanque de armazenamento subterrâneo. A água da chuva infiltra através do solo contaminado com hidrocarbonetos lixiviando alguns dos componentes mais solúveis. Os hidrocarbonetos dissolvidos podem ser degradados durante a migração da água contaminada para os níveis mais inferiores da zona não saturada. A extensão da biodegradação é controlada pela dimensão do derrame, pela taxa de infiltração descendente, e pelas condições subsuperficiais apropriadas. Os hidrocarbonetos dissolvidos que não forem completamente biodegradados na zona não saturada entram na zona saturada e são transportados dentro do nível de água subsuperficial, onde são degradados por microorganismos nativos conforme a disponibilidade de oxigênio e outras condições de subsuperfície. Os contaminantes que não forem degradados movem-se para níveis inferiores sob condições anaeróbicas. A migração da pluma promove a mistura da água anaeróbica com a água rica em oxigênio, segundo as franjas da pluma. Esta é a região onde a maioria das degradações aeróbicas naturais ocorrem. 


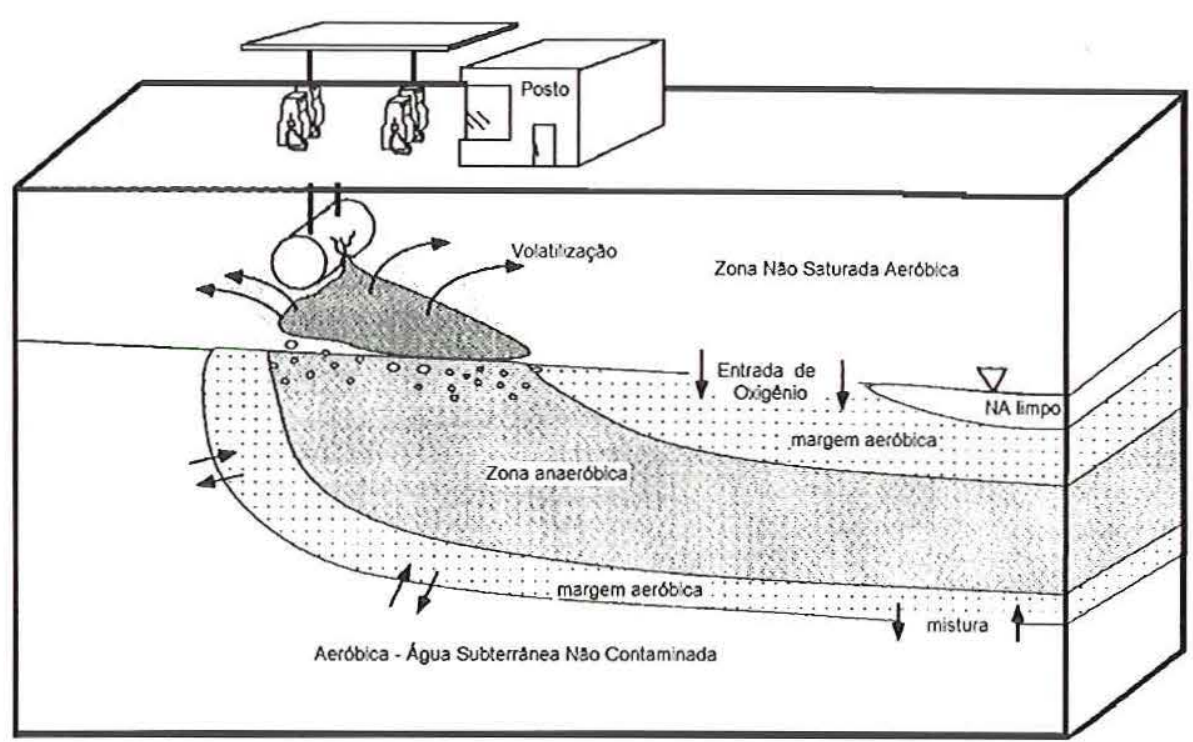

FIGURA 9: Esquema de uma pluma de hidrocarbonetos típica tratada por bioremediação natural (NORRIS, 1994).

Os sistemas de bioremediação in-situ são muitas vezes integrados, seqüencialmente ou simultaneamente, com outras tecnologias de remediação. Por exemplo, a aplicação de vapor in-situ, pode ser usada para a remoção de hidrocarbonetos voláteis e para o fornecimento de oxigênio para a bioremediação. Esses sistemas também podem reduzir os níveis de hidrocarbonetos da fase residual, bem como dos constituintes adsorvidos na zona não saturada e zonas que tenham passados por processos de secagem e umidecimento.

\subsection{PRINCIPAIS TÉCNICAS DE REMEDIAÇÃO}

As principais técnicas utilizadas na remediação de combustíveis no solo são:

- Biodegradação: a biodegradação utiliza microorganismos indígenas ou inoculados (exemplo: fungos, bactérias e outros micróbios) para degradar os contaminantes orgânicos existentes no solo e/ou na água subsuperficial. Na presença de oxigênio, condições aeróbicas, os organismos convertem muitos contaminantes orgânicos em dióxido de carbono, água e massa celular microbiana. Na ausência de oxigênio, condições anaeróbicas, os contaminantes são transformados em metano. Por vezes os contaminantes podem não ser completamente degradados, mas apenas transformados em produtos intermediários que podem ser menor, igualmente, ou mais perigosos do que o contaminante original. 
A bioventilação é uma técnica in situ que utiliza injeção de ar para aumentar a taxa de biodegradação.

- Extração de Vapor do Solo: é uma técnica de remediação in situ, que age na zona não saturada através da aplicação de vácuo para induzir um fluxo de ar controlado e remover os contaminantes voláteis e semivoláteis do solo. O gás retirado pode ser tratado para recuperar ou destruir os contaminantes.

- Desorção Termal a Baixa Temperatura: são processos de separação física que não têm como objetivo destruir os compostos orgânicos. Os resíduos são aquecidos entre 90 e $315^{\circ} \mathrm{C}$ para volatilizar a água e os contaminantes orgânicos. Um sistema de vácuo ou gás transporta a água volatilizada e os contaminantes orgânicos para um sistema de tratamento de gás. O tratamento da água subsuperficial concentra os contaminantes coletados (adsorção do carbono ou condensação).

As principais técnicas utilizadas na remediação de combustíveis presentes na água subsuperficial são:

- Extração de Ar: envolve a transferência de massa de contaminantes voláteis da água para o ar. Para a água subsuperficial, este tratamento é tipicamente realizado em torres agrupadas ou em tanques de aeração.

- Adsorção de Carbono da Fase Líquida: é uma técnica na qual a água subsuperficial é bombeada através de uma série de recipientes contendo carbono ativado, nos quais os contaminantes dissolvidos são adsorvidos.

- Recuperação de Produtos Livres: a fase orgânica líquida não dissolvida é removida das formações subsuperficiais tanto por métodos ativos (bombeamento) ou por sistema de coleta passiva (barreiras). Este processo é utilizado principalmente nos casos onde o combustível flutua sobre o nível de água. O produto livre geralmente é trazido à superfície através de um sistema de bombeamento. Após ser recuperado, pode ser descartado, reutilizado em operações que não necessitem de material com alto grau de pureza, ou ainda ser purificado para reutilização. Os sistemas podem ser projetados para recuperar o produto único, produtos misturados e água, ou separar os fluxos de produtos e de água. 
- Bombeamento e Tratamento: o sistemas de bombeamento e tratamento são destinados à remoção dos contaminantes presentes na fase dissolvida e livre, mas não apresentam bom desempenho na remoção dos contaminantes sorvidos nas partículas do solo e geralmente são pouco efetivos na redução da concentração do contaminante até os níveis permitidos para água potável. O sistema consiste da instalação de poços de extração para capturar a pluma de contaminante, os quais são conectados à uma rede transportadora para levar a água subsuperficial extraída à uma área de tratamento. Esses sistemas geralmente operam em conjunto com outras tecnologias de remediação que podem remover compostos da fase adsorvida e da fase vapor (GWINN \& READ, 1997).

\subsection{MODELAGEM}

Modelos numéricos são uma ferramenta baseada em relações matemáticas, as quais representam, através do código de computador, uma série de leis físicas ou químicas, aplicadas a um determinado problema.

Segundo SPITZ \& MORENO (1996), os modelos numéricos, por apresentarem a melhor aproximação dos problemas de fluxo de água subsuperficial, superou todos os outros tipos de modelos de fluxo subsuperficial, deve-se porém evitar a super estimativa do seu potencial.

Para uma análise do problema de fluxo subsuperficial são necessárias suposições e simplificações dos parâmetros envolvidos. Um modelo, não importa quão sofisticado, nunca descreverá o sistema de fluxo de água subsuperficial real, por isso o usuário do modelo deve sempre entender as implicações das simplificações adotadas SPITZ \& MORENO (1996).

\subsubsection{Tipos de Modelos}

Os modelos mais utilizados são:

- Modelos Analíticos;

- Modelos de Meios Porosos;

- Modelos de Fluidos Viscosos;

- Modelos de Membrana;

- Modelos de Analogia Elétrica;

- Modelos Empíricos;

- Modelos de Balaço de Massa;

- Modelos Numéricos. 


\subsubsection{Modelos Analíticos}

As soluções analíticas tradicionais são restritas devido à grande quantidade de simplificações necessárias à sua utilização. Por outro lado, os modelos analíticos são mais eficientes do que os outros tipos de modelos pois facilitam o estudo da influência de parâmetros individuais e a descrição das condições de equilíbrio de fluxo bidimensionais, para sistema de fluxo homogêneo. Segundo KRUSEMAN \& DE RIDDER, (1970), as soluções analíticas são tradicionalmente utilizadas em análises de testes de bombeamento.

\subsubsection{Modelos de Meios Porosos}

No modelo de meio poroso (Figura 10), o sistema de água subsuperficial pode ser representado em laboratório numa escala apropriada, com as suas propriedades hidrogeológicas distribuídas nas mesmas proporções de espaço e magnitude do sistema natural. Assim, o modelo pode ser manejado e o sistema de fluxo registrado, possibilitando conhecer o comportamento do sistema real (SPITZ \& MORENO, 1996).

As similaridades entre o sistema natural e o modelo, tais como área, geometria, etc, são definidas através de relações matemáticas. Na prática são utilizados modelos físicos para avaliar um fluxo em particular ou problemas relacionados ao transporte.

\subsubsection{Modelos de Fluxo Viscoso}

Este modelo é utilizado para demonstrar o transporte de um fluxo viscoso, tal como glicerina, entre planos paralelos e de pequeno espaçamento, e para um fluxo de água subsuperficial bidimensional (Figura 10). Embora o modelo de fluido viscoso possa ser do tipo horizontal ou vertical, no entanto este último tem sido mais aplicado. Estes modelos tem sido aplicados no estudo de fluxo e do espalhamento através de barragens e intrusões salinas. SCHWILLE (1988) aplicou este tipo de modelo no estudo de fluxo de água subsuperficial e do transporte em rochas fraturadas.

Os modelos numéricos têm diminuído a importância deste tipo de modelo, o qual vem sendo utilizado apenas para efeitos de demonstração. 
Modelos de Meios Porosos

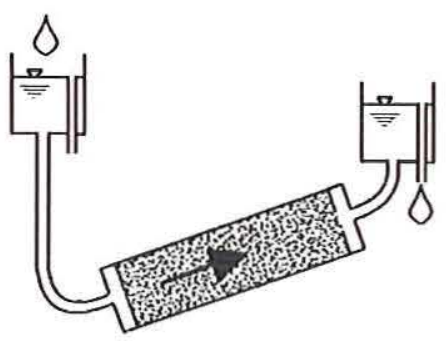

Modelos de Membrana

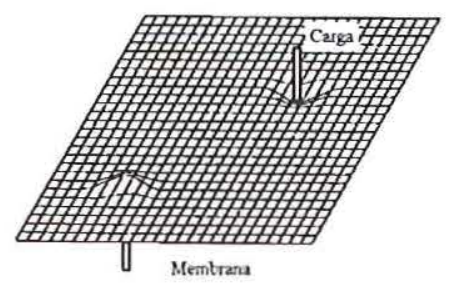

Modelo de Balanço de Massa

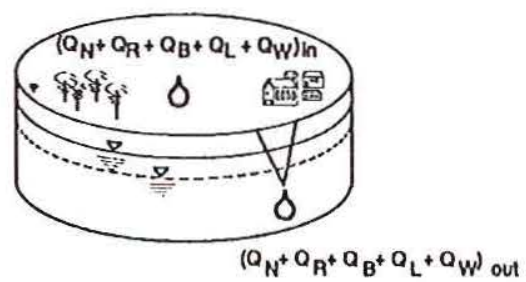

Modelo de Fluido Viscoso

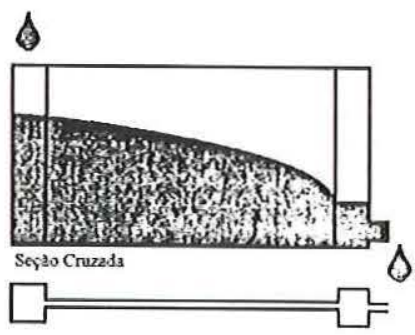

Modelo de Analogia Elétrica

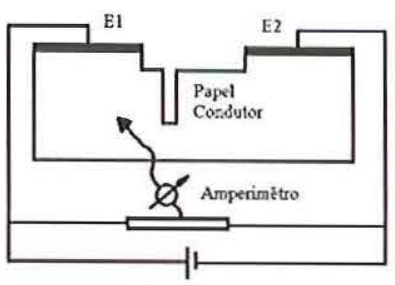

Modelo Numérico

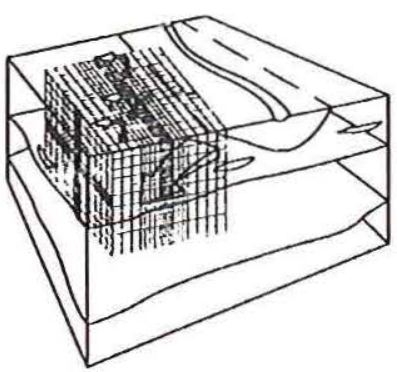

FIGURA 10: Exemplos de modelos de água subsuperficial (SPITZ \& MORENO (1996).

\subsubsection{Modelos de Membrana}

O modelo de membrana consiste de um mecanismo para abaular uma membrana situada sobre uma base, e um dispositivo para medir precisamente as deformações correspondentes. Para representar um poço único, por exemplo, pode-se aplicar uma força pontual em um determinado ponto sobre a membrana e assim formar uma depressão. No caso de um poço em bombeamento, o topo da membrana é rebaixado, enquanto que para um 
poço de injeção a força pontual deve ser posicionada abaixo da membrana formando uma saliência (Figura 10). HANSEN (1949) descreve a semelhança entre a deformação do nível de água subsuperficial devido à extração de água através de poços e a deflecção de membranas delgadas devido ao deslocamento vertical do ponto discreto. Este modelo é, portanto, considerado uma ferramenta para visualizar as pressões atuantes no sistema de água subsuperficial.

\subsubsection{Modelos de Analogia Elétrica}

Esse modelo é baseado na relação entre o fluxo elétrico e o fluxo de água subsuperficial. O meio no qual o fluxo elétrico é estudado pode ser um sensor de papel, um tanque de eletrólise ou uma série de resistências elétricas. O papel condutor é uma ferramenta para simular o fluxo bidimensional de água subsuperficial. Uma voltagem equivalente $E$ é aplicada em ganchos de cobre descascados conectados ao papel condutor e assim as linhas de queda de potencial, que representam linhas de frente constante, podem ser facilmente medidas (Figura 10). De acordo com WALTON (1970), pode-se utilizar equações matemáticas para relacionar as unidades elétricas medidas no experimento e as unidades hidráulicas associadas ao sistema de água subsuperficial.

\subsubsection{Modelos Empíricos}

Os modelos empíricos são utilizados para representar processos físicos ou químicos através de generalizações, simplificações, ou em uma escala maior do que o próprio processo. Esses modelos são de dois tipos:

1) Modelos que representam processos individuais ou mecanismos;

2) Modelos que representam o problema da água subsuperficial como um todo.

Exemplos do primeiro tipo incluem a Lei de Darcy, a Lei de Fick e as isotermas de adsorção. Esses modelos estão embutidos em modelos analíticos e numéricos e são utilizados quando na ausência de dados detalhados do local ou quando não há possibilidade de simular os processos em escalas pequenas. Funciona portanto como uma solução temporária para auxiliar análises posteriores.

Os modelos empíricos que representam um problema de água subsuperficial por completo envolvem uma série de leis físicas, empíricas e suposições conservativas para representar os problemas de fluxo de interesse. Exemplos de tais modelos incluem o modelo de análises de aterros HELP (SCHROEDER, 1994), e o modelo de avaliação de exposição MULTIMED (USEPA). Esses modelos são aplicáveis apenas em circunstâncias limitadas e, por não distinguir processos, ocultam suas limitações. 


\subsubsection{Modelos de Balanço de Massa}

Esse modelo, também conhecido como modelo de célula única, é considerado um modelo numérico simplificado. Os fluxos de massa, tanto de água subsuperficial (balanço de água) quanto de algum constituinte (balanço de soluto) são balanceados em grandes volumes, para quantificar a transferência de massa que ocorre nas reações e determinar as condições sob as quais estas reações ocorrem. Apesar de sua simplicidade, este tipo de modelo é usual, uma vez que facilita a análise global do balanço de massa e complementam a modelagem numérica através da comparação entre o balanço de massa nos estágios iniciais dos cálculos.

\subsubsection{Modelos Numéricos}

Os modelos numéricos representam basicamente uma assembléia de vários modelos de célula única, aplicáveis à problemas de fluxo de água subsuperficial e de transporte de massa, simples e complexos. A bibliografia defende que esses modelos não apresentam restrições quanto ao tipo de barreira, condições iniciais, características do sistema de água subsuperficial ou características do soluto investigado. No entanto, deve-se ter cuidado na escolha do programa a ser utilizado, pois geralmente os mesmos apresentam limitações quanto a sua aplicação.

O termo modelo numérico refere-se a combinação da descrição matemática, o código numérico do programa computacional e sua aplicação nos problemas específicos de água subsuperficial.

O código numérico é uma ferramenta que resolve a equação que governa o fluxo ou o trạnsporte de massas. Este código é transformado em um modelo de água subsuperficial incorporando a geometria específica do local e os limites que o condicionam, introduz-se também o fluxo atual e os parâmetros de transporte, além de calibrar e verificar o modelo.

Os modelos numéricos são uma ferramenta para resolver problemas mas não são a solução propriamente dita pois não oferecem respostas precisas à problemas insuficientemente definidos (SPITZ \& MORENO, 1996).

\subsubsection{Etapas de criação de um modelo numérico}

Qualquer modelo numérico é executado a partir das seguinte fases:

- Compilação e interpretação dos dados de campo;

- Entendimento do meio físico; 
- Conceituação do sistema natural;

- Seleção do modelo numérico;

- Calibragem e validação do modelo;

- Aplicação do modelo;

- Apresentação dos resultados.

\subsubsection{Compilação e Interpretação dos Dados de Campo}

Os dados de campo são essenciais para entender o meio físico, especificar o problema de água subsuperficial investigado, auxiliar na seleção do programa computacional, e fornecer os parâmetros de entrada. O modelo numérico na verdade desenvolve um modelo de água subsuperficial de um local específico quando são nomeados parâmetros reais de campo. A qualidade das simulações depende em grande parte da validade do modelo físico e dos dados de entrada. Os dados de campo não devem ser coletados aleatoriamente, mas sim de acordo com as necessidades do modelo a ser desenvolvido.

\subsubsection{Entendimento do Meio Físico}

Para obter uma modelagem adequada, o usuário deve entender o meio físico, ou seja, a distribuição dos parâmetros geológicos e as condições limites devem ser identificadas, como mostra a Figura 11. Além disso, é importante ter uma definição clara do problema de fluxo e de transporte envolvido no estudo. Ao mesmo tempo o modelo deve ser simples o suficiente para facilitar os esforços necessários, mas não tão simples a ponto de excluir características importantes do problema de água subsuperficial investigado.

\subsubsection{Conceituação do Meio Físico}

Em cada modelo, o meio físico é representado por um modelo conceitual, como esquematicamente mostrado na Figura 11, para o qual é aplicada uma solução aproximada.

\subsection{2..4. Seleção do Modelo Numérico}

Deve-se decidir qual o modelo numérico aplicável ao problema investigado. A maioria dos modelos numéricos são similares quanto a área investigada ser subdividida em segmentos poligonais irregulares ou retangulares (Figura 11). Em cada modelo a escolha pela discretização do espaço e do tempo praticamente controla a eficácia computacional. 
ENTENDENDO O MEIO FÍSICO

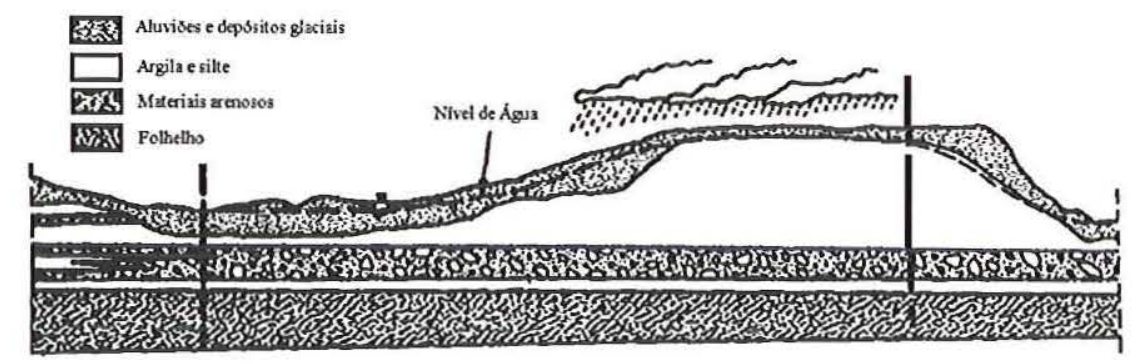

CONCEITUANDO O SISTEMA NATURAL

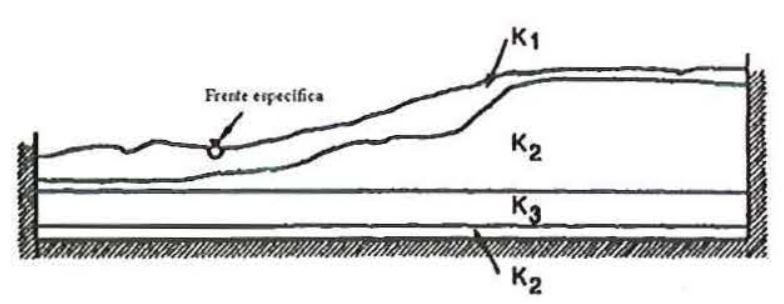

SELECIONANDO O MODELO NUMÉRICO

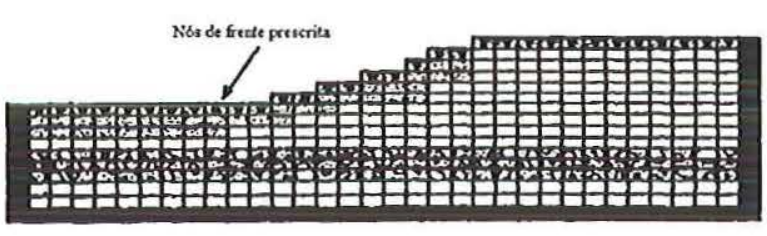

- Flatoprevirto

APLICAÇÃO DO MODELO

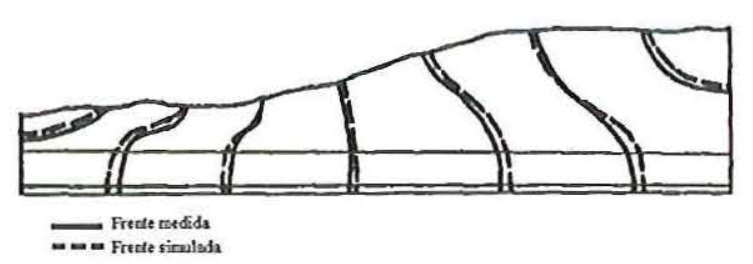

FIGURA 11: Exemplos de algumas das principais fases de elaboração de um modelo numérico. 


\subsubsection{Calibragem e Validação do Modelo}

$\mathrm{Na}$ calibragem os valores simulados como superfície potenciométrica ou concentrações são comparadas com medidas de campo. Os dados de entrada do modelo são alterados dentro dos intervalos observados até que os valores simulados e observados estejam ajustados dentro de uma tolerância escolhida.

A validação do modelo é necessária para demonstrar que o modelo pode ser utilizado para realizar previsões.

\subsubsection{Aplicação do Modelo}

A aplicação do modelo é a parte do estudo na qual o modelo numérico demonstra ser superior a outros modelos. Existem limitações na aplicação dos modelos numéricos de tal forma que as previsões mais distantes em termos de tempo são as mais incertas. Outras limitações podem estar envolvidas, por exemplo o programa não ser aplicado ao tipo de contaminante investigado ou não considerar aspectos importantes do meio físico.

As previsões devem ser baseadas em valores bem conhecidos e os modelos resultantes devem ser cuidadosamente revisados através da análise de sensibilidade.

\subsubsection{Apresentação dos Resultados}

A apresentação dos dados de saída do modelo pode representar uma exatidão que na realidade não existe. Muitas vezes são necessárias interpolações e extrapolações dos dados para facilitar a interpretação dos dados, mas essa é uma medida que pode encobrir incertezas nos resultados do modelo.

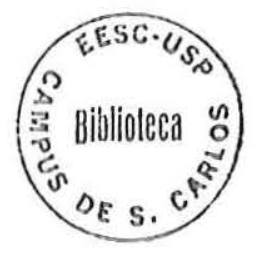




\subsection{CONSIDERAÇÕES INICIAIS}

Em função da ausência de uma metodologia aplicada ao estudo de problemas ambientais envolvendo dutos enterrados, propõe-se a metodologia apresentada na Figura 12, a qual mostra as etapas desenvolvidas na realização deste trabalho.

\subsection{REVISÃO BIBLIOGRÁFICA}

Nesta etapa foram consultadas bibliografias referentes à caracterização dos contaminantes orgânicos, aos aspectos estruturais e construtivos dos dutos e à modelagem computacional do comportamento de contaminantes no meio físico.

No que diz respeito aos contaminantes orgânicos foram obtidas informações de suas características físico-químicas e de periculosidade, bem como do comportamento desses produtos no meio físico quanto à migração, transporte, transferências de massa, biotransformação, dissolução e das várias possibilidades de poluição que estes contaminantes costumam gerar no meio ambiente.

As bibliografias consultadas quanto aos aspectos estruturais e construtivos dos dutos, permitiram definir quais são as estruturas e mecanismos freqüentemente sujeitos a falha ou mal funcionamento, bem como as prováveis causas desses danos.

A consulta à bibliografias sobre modelagem computacional foi motivada pelo interesse em representar o comportamento dos contaminantes orgânicos no meio físico. Nesta fase foi possível entender a complexidade da elaboração de modelos computacionais que representem as condições reais de contaminação envolvendo os produtos orgânicos. 


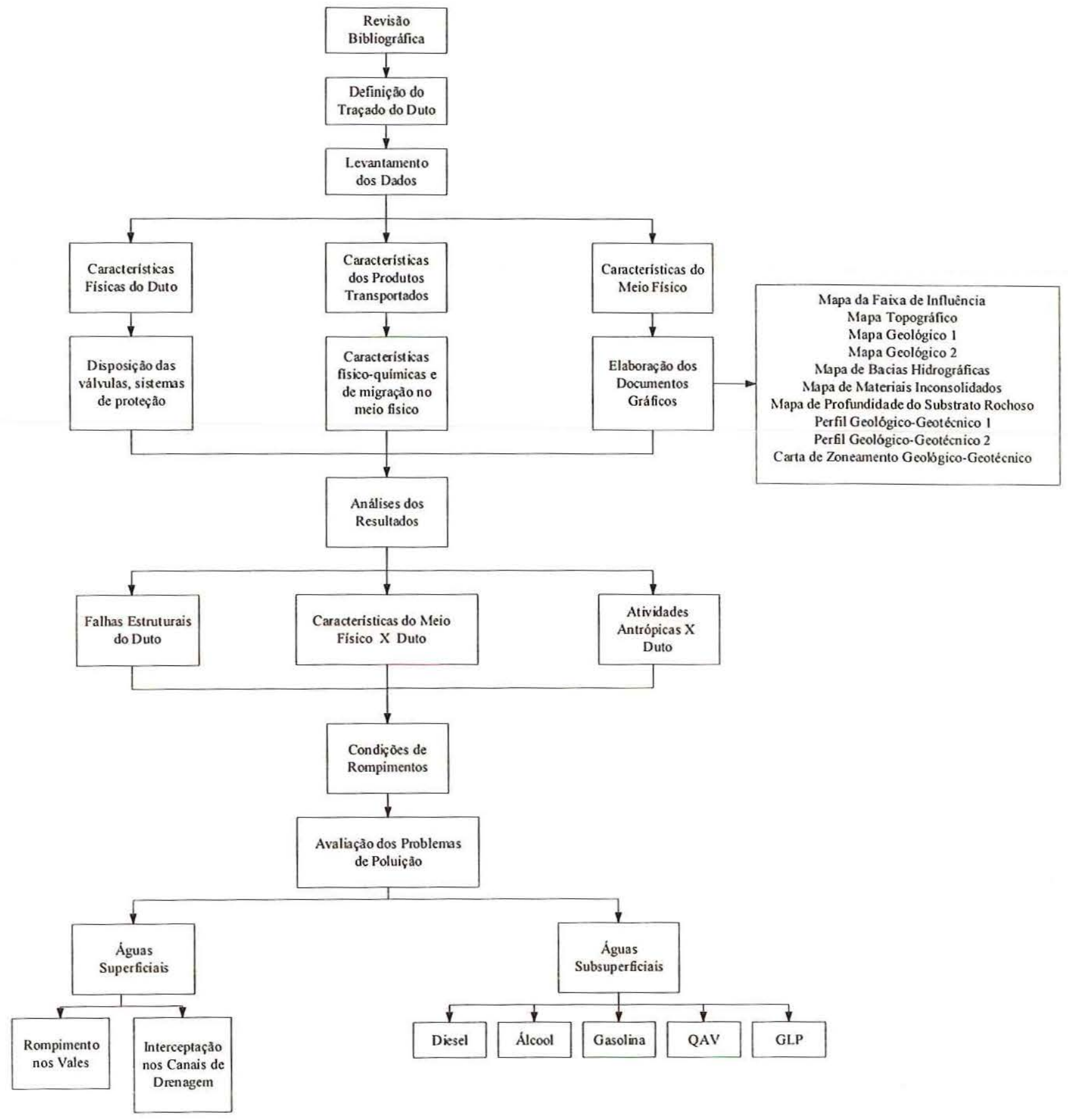

FIGURA 12: Fluxograma da metodologia proposta. 


\subsection{DEFINIÇÃO DO TRAÇADO DO DUTO}

De posse do mapa de traçado do duto fornecido pela Petrobrás, notou-se que parte do traçado representado neste mapa não correspondia ao posicionamento real do duto. Foi necessário definir o posicionamento correto do duto, com o auxílio dos mapas topográficos do IBGE, na escala 1:50.000. O traçado definitivo foi modificado a partir do $\mathrm{Km} 155$ do duto, após o Ribeirão do Tamanduá, próximo as coordenadas UTM 7626 Km e 228 Km (Mapa da Faixa de Influência, ANEXO 2).

\subsection{COLETA E OBTENÇÃO DE INFORMAÇÕES}

Nesta etapa foram coletados dados do meio físico, do duto e dos produtos transportados pelo OSBRA.

\section{Meio Físico}

Na Tabela 9 encontra-se os atributos do meio físico que devem ser levantados na investigação dos problemas ambientais relacionados a dutos. $\mathrm{O}$ modelo de ação proposto nesta tabela é de buscar levantar todos os componentes que ocorrem na área investigada, partindo-se de seu aspecto geral até os atributos específicos. Tem por objetivo determinar quais os atributos que podem interagir com o duto provocando acidentes e quais podem estar relacionados aos problemas de poluição gerados após o vazamento.

Devido à ausência de uma metodologia aplicada ao estudo de dutos, optou-se por adotar a Tabela 9 adequando-a para a realização deste trabalho. Assim sendo, foram investigados apenas os atributos que ocorrem na área e que apresentam maior importância no trecho. Desta forma, estão assinalados com "D" os atributos que influenciam diretamente os problemas geológico-geotécnicos (GL/GT) e/ou os problemas de poluição, com "I" os atributos que influenciam indiretamente, com "NE" os atributos inexistentes na área ou aqueles cujas informações não estavam disponíveis na bibliografia, e com "NC" os atributos que não foram considerados nesse estudo em função da sua irrelevância na área estudada.

\section{Duto e Produtos Transportados}

Nesta etapa foram coletados dados sobre as características físicas do duto e sobre as características físico-químicas dos produtos transportados, através da consulta dos relatórios de impacto ambiental (RIMA), junto à CETESB e das escassas informações cedidas pela Petrobrás.

É importante ressaltar que os relatórios de impacto ambiental foram embasados no 
TABELA 10: Atributos que devem ser levantados de acordo com ZUQUETTE (1997) no processo de mapeamento geotécnico, a partir dos quais podem ser analisados os problemas ambientais relacionados as características geológico-geotécnicas em termos dos dutos. Modificado de ZUQUETTE (1997).

\begin{tabular}{|c|c|c|c|c|c|c|}
\hline $\begin{array}{l}\text { Compon } \\
\text { entes }\end{array}$ & Tipo/Aspecto & $\begin{array}{l}\text { Agrupa } \\
\text {-mento }\end{array}$ & Atributos & $\begin{array}{c}\text { Considerado quanto ao } \\
\text { meio fisico X duto }\end{array}$ & $\begin{array}{c}\text { Considerados nos } \\
\text { Problemas de Poluição }\end{array}$ & $\begin{array}{c}\text { Considerados neste } \\
\text { trabalhos }\end{array}$ \\
\hline \multirow{13}{*}{ Águas } & \multirow[t]{7}{*}{ Superficiais } & & - Escoamento superficial & $\mathrm{X}$ & $\mathrm{X}$ & I \\
\hline & & & - Infiltração (Infiltração potencial) & $\mathrm{X}$ & $\mathrm{X}$ & I \\
\hline & & & $\begin{array}{l}\text { - Areas de acúmulo de águas } \\
\text { (temporário e permanente) }\end{array}$ & $\mathrm{X}$ & & $\mathrm{D}$ \\
\hline & & & $\begin{array}{l}\text { - Bacias hidrográficas desde } 1^{a} \\
\text { ordem (Segundo Strahler) }\end{array}$ & $\mathrm{X}$ & & $\mathrm{D}$ \\
\hline & & & - Densidade de canais/Km & $\mathrm{X}$ & & $\mathrm{D}$ \\
\hline & & & - Tempo de concentração & & & $\mathrm{NC}$ \\
\hline & & & $\begin{array}{l}\text { - Canais de drenagens com fluxo } \\
\text { permanente }\end{array}$ & & & $\mathrm{D}$ \\
\hline & \multirow[t]{6}{*}{ Subterrâneas } & & - Aqüíferos (livres, confinados) & & $\mathrm{X}$ & $\mathrm{D}$ \\
\hline & & & - Areas de recargas & & $\mathrm{X}$ & $\mathrm{D}$ \\
\hline & & & -Profundidade/espessura do aqüífero & $\mathrm{X}$ & $\mathrm{X}$ & $\mathrm{D}$ \\
\hline & & & - Fontes naturais (posição espacial) & & $\mathrm{X}$ & $\mathrm{NC}$ \\
\hline & & & - Poços existentes & & $\mathrm{X}$ & I \\
\hline & & & - Escoamento básico & & $\mathrm{X}$ & $\mathrm{NC}$ \\
\hline
\end{tabular}




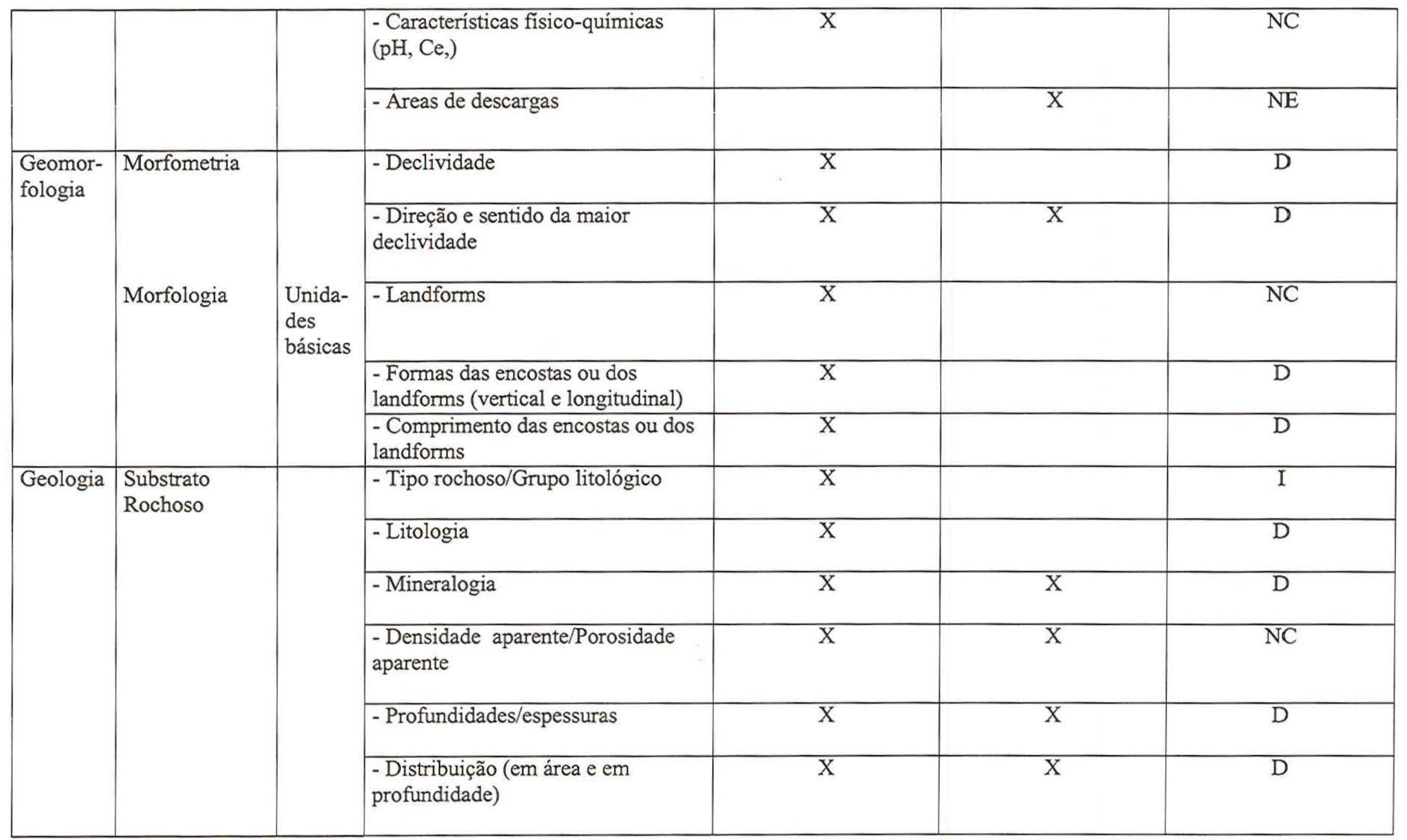




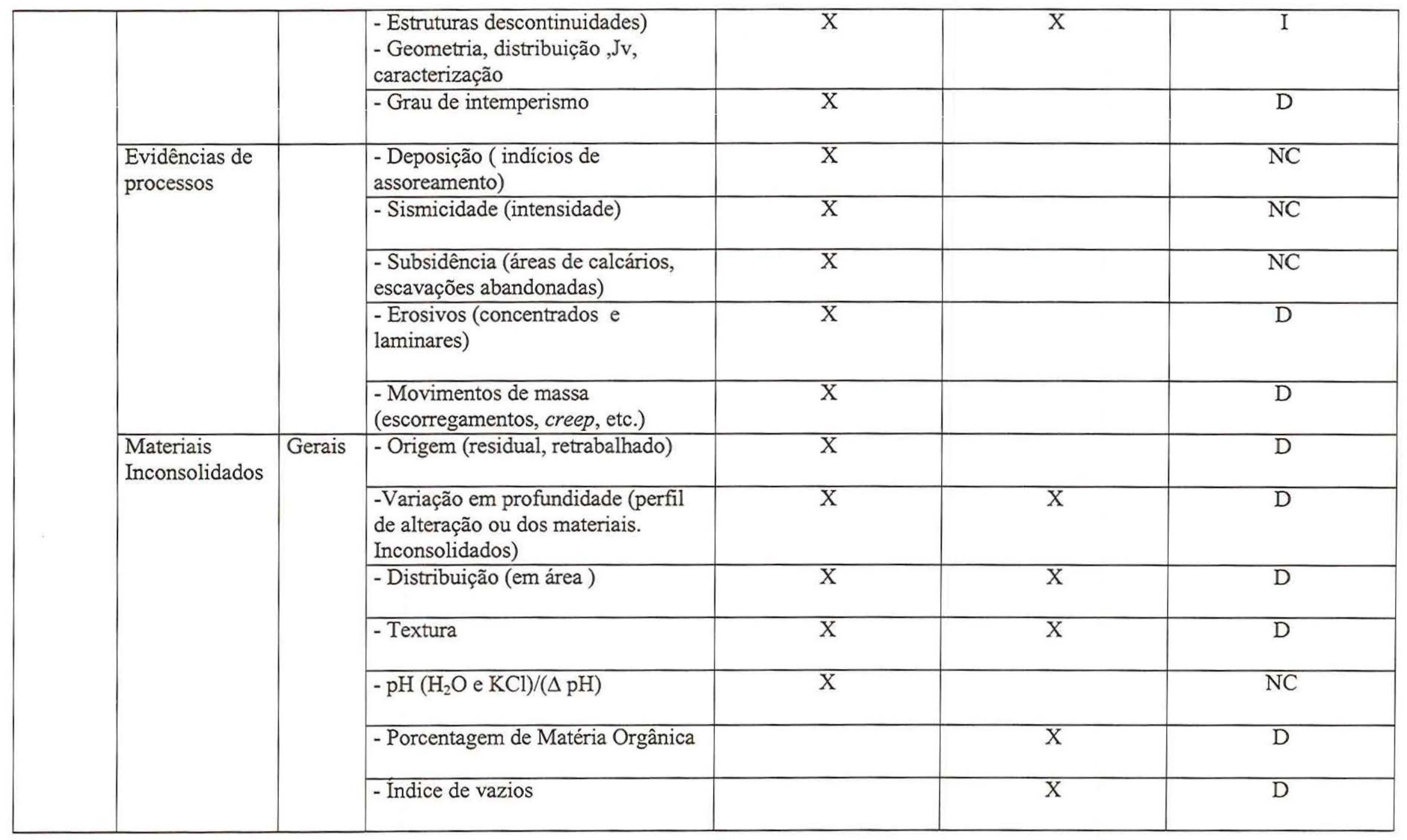




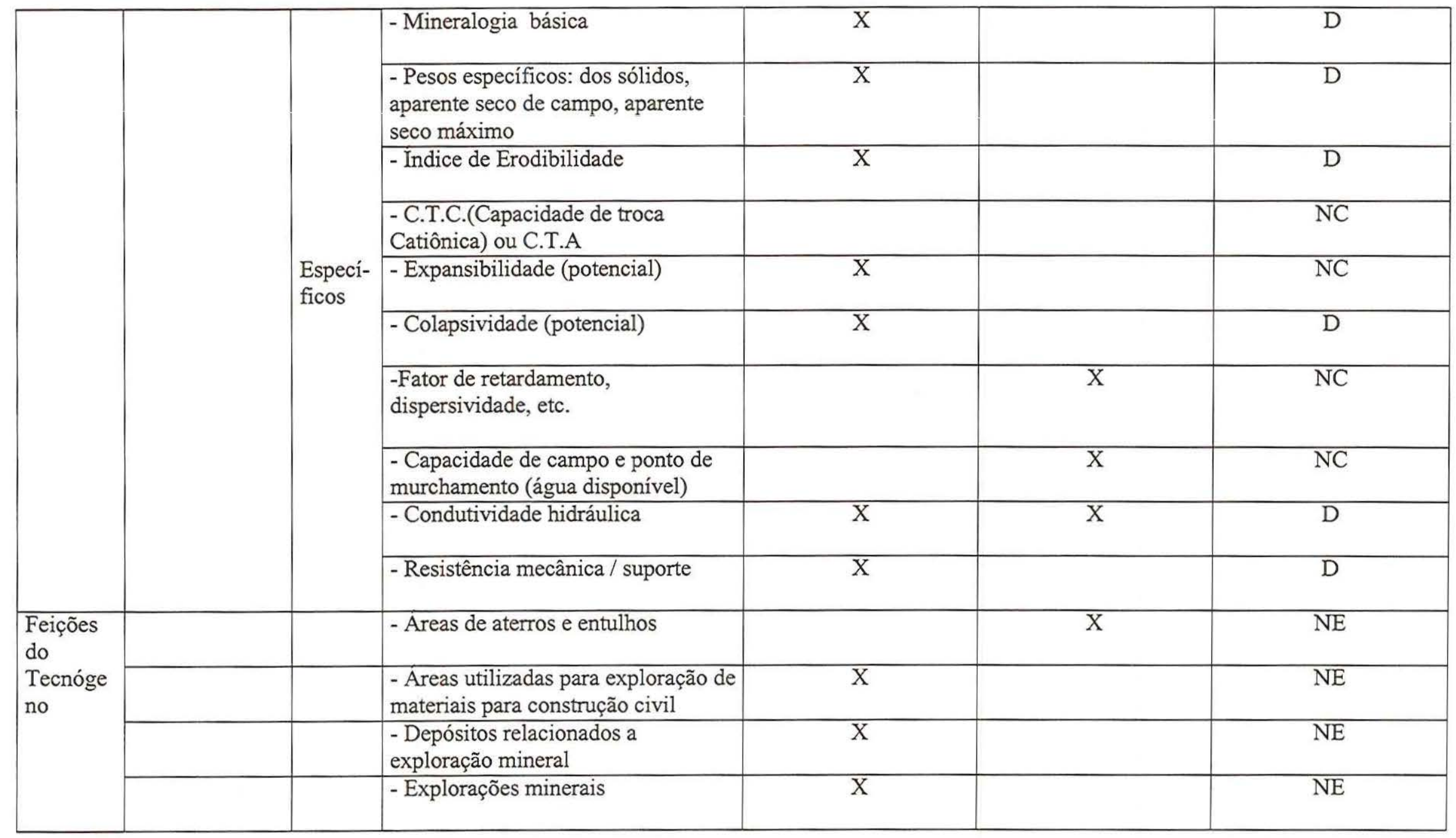




\begin{tabular}{|c|c|c|c|c|}
\hline \multirow{7}{*}{$\begin{array}{l}\text { Climátic } \\
\text { os }\end{array}$} & $\begin{array}{l}\text { - Antigos depósitos de rejeitos e } \\
\text { resíduos }\end{array}$ & & $\mathrm{X}$ & $\mathrm{NE}$ \\
\hline & $\begin{array}{l}\text { - Depósitos devido as alterações } \\
\text { antrópicas junto aos canais de } \\
\text { drenagens }\end{array}$ & $\mathrm{X}$ & & $\mathrm{NE}$ \\
\hline & - Áreas irrigadas & $\mathrm{X}$ & $\mathrm{X}$ & $\mathrm{D}$ \\
\hline & $\begin{array}{l}\text { - Exploração agrícola com uso de } \\
\text { insumos químicos }\end{array}$ & & $\mathrm{X}$ & $\mathrm{D}$ \\
\hline & - Pluviosidade & $\mathrm{X}$ & & $\mathrm{D}$ \\
\hline & - Intensidade pluviométricas & $\mathrm{X}$ & $\mathrm{X}$ & NC \\
\hline & - Distribuição temporal das chuvas & $\mathrm{X}$ & $\mathrm{X}$ & $\mathrm{D}$ \\
\hline
\end{tabular}

$\mathrm{X}-$ Atributos a serem considerados.

D - Atributo diretamente considerado neste trabalho.

I - Atributo indiretamente considerado.

$\mathrm{NE}$ - Atributo inexistente na área ou aquele cujas informações não estavam disponíveis na bibliografia.

$\mathrm{NC}$ - Atributo não considerado. 
traçado inicialmente proposto e não no definitivo, ou seja, os relatórios não contêm dados sobre os duto no trecho modificado. Em vista disto, a disposição das válvulas no trecho modificado, foi verificada nas visitas de campo.

\subsubsection{Etapa de Campo}

$\mathrm{Na}$ etapa de campo foram registradas as condições físicas do duto, as evidências dos eventos geológico-geotécnicos atuantes na área, além da verificação e distribuição das litologias, dos diferentes tipos de materiais inconsolidados e das águas.

\subsection{ELABORAÇÃO DOS DOCUMENTOS CARTOGRÁFICOS}

A elaboração dos documentos cartográficos ocorreu concomitante à fase anterior, sendo elaborados os seguintes documentos:

- Mapa das Bacias Hidrográficas Interceptadas pelo Duto;

- Mapa da Faixa de Influência;

- Mapa Topográfico;

- Mapas Geológico 1;

- Mapas Geológico 2;

- Mapa de Materiais Inconsolidados;

- Mapa de Profundidade do Substrato Rochoso;

- Perfil Geológico-Geotécnico 1;

- Perfil Geológico-Geotécnico 2;

- Carta de Zoneamento Geológico-Geotécnico.

Todos os documentos cartográficos representativos da faixa de influência do duto, isto é, os mapas e as cartas foram impressas na escala 1:100.000 e os perfis elaborados com escala horizontal 1:100.000 e vertical 1:2.000, como pode ser observado nos Anexos 1 a 10. Os mapas foram elaborados a partir das folhas do IBGE (1971 e 1982), Ribeirão Preto, Bonfim Paulista, Cravinhos, Luís Antônio, Santa Rita do Passa Quatro, Descalvado, Piraçununga, na escala 1:50.000. A elaboração do Mapa de Materiais Inconsolidados e do Mapa de Profundidade do Substrato Rochoso foi baseada em dados de ZUQUETTE (1993). Todos os documentos gráficos foram digitalizados no programa AutoCAD 14. 
No Mapa Geológico 1 estão representadas as unidades geológicas compiladas de mapeamentos anteriores. Pode-se notar neste mapa, a ausência da Formação Corumbataí, cuja ocorrência foi posteriormente detectada em campo, na região sul da área. O objetivo de manter o primeiro mapa geológico foi mostrar a importância de realizar etapas de campo mesmo que a área já tenha sido anteriormente mapeada.

Através do Perfil Geológico - Geotécnico 1 pode-se observar que a presença da Formação Pirambóia no lugar da Formação Corumbataí, levaria à interpretações muito distintas. Sob o aspecto da contaminação do meio físico, os arenitos da Formação Pirambóia favoreceriam a infiltração dos contaminantes enquanto os argilitos da Formação Corumbataí funcionariam como uma barreira à percolação destes contaminantes.

\subsection{ANÁLISE DOS RESULTADOS}

Definidos os atributos de maior importância na área, partiu-se para a análise dos resultados, baseando-se nos aspectos estruturais do duto, nos fatores relacionados ao meio físico e ao meio antrópico, os quais podem gerar condições de ruptura ou de instabilização do sistema provocando vazamentos.

Os problemas de contaminação decorrentes de vazamentos foram avaliados segundo os locais e as formas que os contaminantes podem atingir o meio físico. Foram adotados perfis esquemáticos para exemplificar os diferentes contextos de contaminação que podem ocorrer no trecho.

\subsection{MODELAGEM DE COMPOSTOS ORGÂNICOS}

Após definir os problemas ambientais existentes no trecho, achou-se necessário modelar o comportamento do contaminante no meio físico em consequiência de um possível vazamento. Para isso seria utilizado o programa computacional Modflow da U.S. Geological Survey (USGS), disponível no Departamento de Geotecnia da EESC, para a realização de modelagem de contaminantes. Dos cinco produtos transportados pelo OSBRA, optou-se por modelar a gasolina em função da escassez de material bibliográfico quanto ao comportamento dos demais produtos no meio físico.

No decorrer da pesquisa deparou-se com alguns problemas relacionados à aplicação do modelo computacional Modflow, e às limitações dos programas numéricos em geral quanto à modelagem de fluxo multifásico. 


\subsubsection{Aplicação do Programa Computacional Modflow}

O Visual Modflow tem por finalidade a modelagem de fluxo da água subsuperficial apenas na zona saturada, admitindo que o contaminante introduzido no sistema seja completamente miscível. Possui um programa de interface denominado MT3D destinado à modelagem de transporte e delimitação da pluma de contaminação ao longo do tempo, utilizando os dados de entrada do Visual Modflow e dados adicionais tais como taxa de sorção, dispersão, decaimento e biotransformação.

\subsubsection{Problemas Relacionados à Modelagem de Compostos Orgânicos}

Os programas de modelagem numérica subdividem a área investigada em células de acordo com a escolha do usuário do modelo. Essa subdivisão, chamada discretização, controla a distribuição das características da área estudada quanto ao nível de detalhe que se deseja alcançar, ou seja determina a resolução das simulações obtidas.

Existe no entanto restrições quanto a representação de dados em áreas muito extensas e o nível de precisão dos resultados que se deseja obter. Áreas extensas, com um grande número de características a serem analisadas, não podem ser muito subdivididas, pois na modelagem cada interação entre as células pode gerar erro acumulativo. Desta forma, a faixa de influência do duto em questão deveria ser subdividida segundo os diferentes contextos de contaminação e as áreas resultantes serem introduzidas separadamente no programa, gerando modelos numéricos individuais para cada situação. Assim seria possível introduzir o maior número de informações possíveis e obter uma discretização satisfatória, gerando equilíbrio entre a representatividade do modelo para o local específico, com menor número de erros acumulativos.

A modelagem de produtos imiscíveis é mais complicada do que a modelagem de contaminantes miscíveis, pois no primeiro caso o programa computacional deve considerar, além das características do meio físico, as propriedades de todos os componentes presentes na mistura que se quer analisar.

Em função do grande número de componentes da gasolina, opta-se pelo estudo dos compostos mais solúveis: benzeno, tolueno, etilbenzeno e xilenos, denominados BTEX.

Dentre as propriedades dos componentes que devem ser consideradas na modelagem de compostos orgânicos estão: número de constituintes analisados, densidade, peso molecular, constante de Henry, solubilidade, coeficientes de partição $K_{o c}$ e $K_{o w}$. 
O resultado que o usuário do modelo busca obter é a modelagem da porção de produto retida na fase sólida, dissolvida na água subsuperficial, presente na fase livre, volatilizada e biotransformada.

Determinar as concentrações de equilíbrio das misturas orgânicas em cada fase torna-se ainda mais complicado devido às interações entre os processos físicos, químicos, biológicos e a influência do material geológico.

A contaminação por DNAPL é mais extensivamente estudada pois estes geralmente consistem de um composto único ou de mistura de 3 ou 4 compostos, e também devido a sua maior persistência no meio ambiente.

Outro problema presente na modelagem da gasolina é que a pluma de contaminação gerada contém vários componentes que migram diferentemente, interagindo entre si. Por isso é mais usual a modelagem dos constituintes mais significativos em termos de mobilidade ou de solubilidade.

Os modelos numéricos no entanto fornecem resultados satisfatórios para questões bem definidas, isto é, antes de modelar o usuário deve buscar utilizar o modelo numérico mais adequado aos resultados que deseja obter, levando em consideração os parâmetros do contaminante e do meio físico capazes de serem tratados pelo modelo.

FERREIRA et al. (1998) estudaram o particionamento de 12 compostos orgânicos da gasolina em misturas ternárias água-etanol-gasolina. O material arenoso utilizado nos testes foram coletados da Formação Botucatu e as análises realizadas através de ensaios de coluna e de solubilidade.

Adicionalmente FERREIRA (no prelo) utilizou os resultados de suas análises laboratoriais, em solos não saturados, para modelar a taxa de transferência de massa de compostos orgânicos na zona não saturada. O programa R-UNSAT da U. S. Geological Survey (USGS) utilizado, quantifica a taxa de volatilização e biodegradação de compostos orgânicos próximos ao nível de água, e pode ser aplicado aos problemas de transporte na zona não saturada. R-UNSAT também pode ser usado para a calibragem de dados laboratoriais e na previsão da distribuição de espécies químicas em função do tempo e do espaço e estimar as perdas de massa impostas pelas condições de contorno utilizadas no modelo. Na calibragem o R-UNSAT quantifica as taxas de transporte de massa, taxas de reação ou as propriedades hidrodinâmicas da zona não saturada. 


\subsection{LOCALIZAÇÃo DA ÁREA}

A área estudada está localizada na porção nordeste do Estado de São Paulo (Figura 13), correspondendo a um trecho de aproximadamente $100 \mathrm{Km}$ do duto OSBRA (Oleoduto São Paulo - Brasília), situado entre a Estação de Bombeamento de Ribeirão Preto e o Rio Mogi-Guaçu, nas proximidades da cidade de Porto Ferreira. A área pesquisada abrange os municípios de Ribeirão Preto, Bonfim Paulista, Luís Antônio, Cravinhos, Sertãozinho, Dumont, Porto Ferreira. (ANEXO 1).

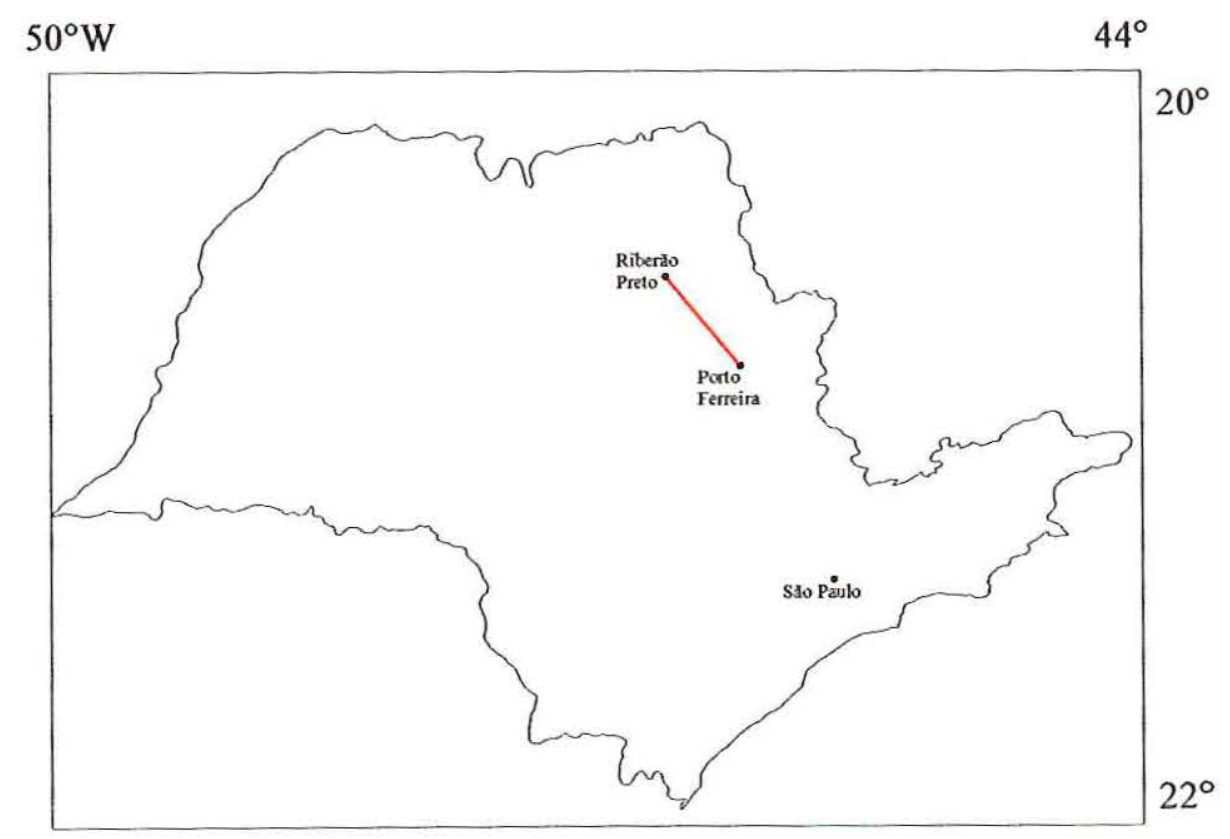

FIGURA 13: Localização da área. 
A principal via de acesso à área é a rodovia Anhangüera (SP - 330), sentido São Paulo - Ribeirão Preto, podendo-se chegar ao duto através de várias estradas secundárias.

A área selecionada abrange as folhas Pitangueiras, Ribeirão Preto, Serrana, Guariba, Bonfim Paulista, Cravinhos, Rincão, Porto Pulador, Luís Antônio, Santa Rita do Passa Quatro, Descalvado, Piraçununga, em escala 1:50.000, do IBGE (1971 e 1982)

\subsection{CARACTERÍSTICAS FÍSICAS E DISTRIBUIÇÃO DOS COMPONENTES DO DUTO}

O poliduto OSBRA é constituído de aço, possuindo revestimento de proteção em suas paredes externas. Foi construído com diâmetro nominal de 20" e instalado a 1,5 metros de profundidade, perfazendo uma extensão de $194 \mathrm{Km}$ de linha dutoviária somente no Estado de São Paulo e interligando a REPLAN (Refinaria do Planalto) à Base de distribuição de Ribeirão Preto (Figura 14).

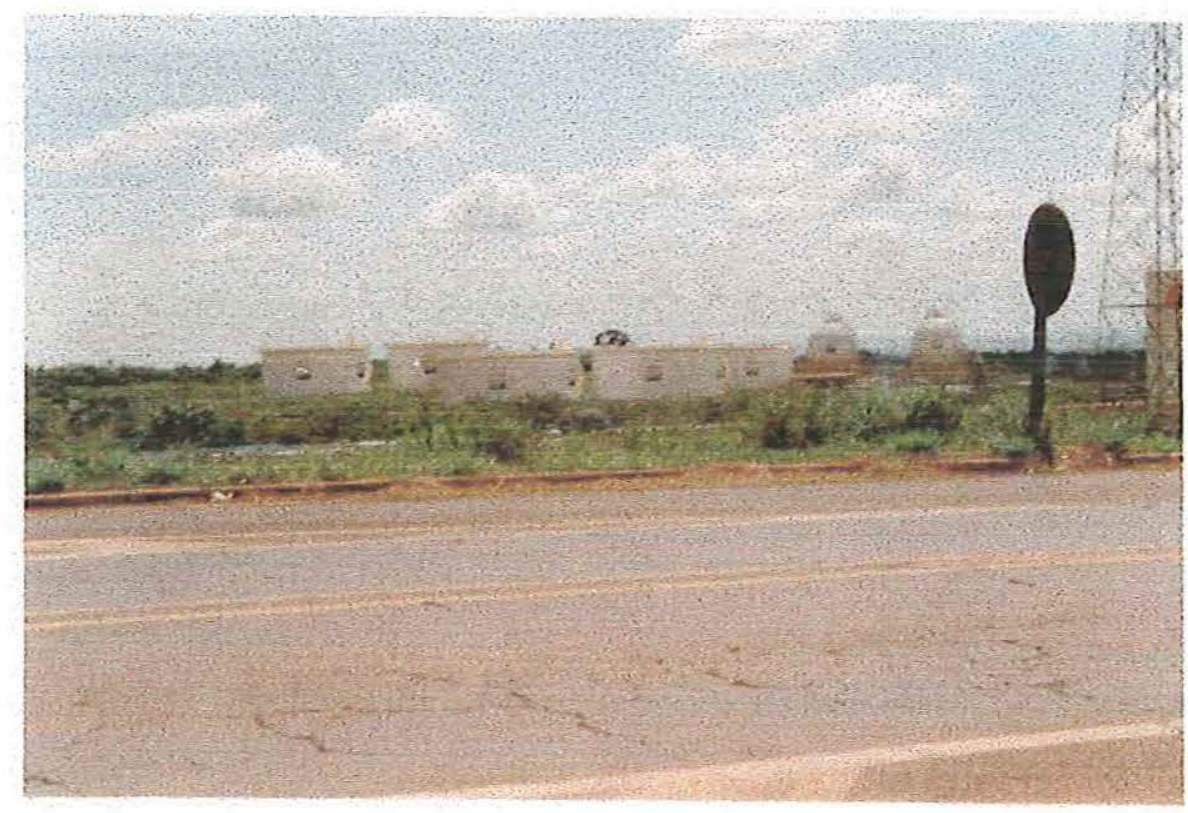

FIGURA 14: Base de distribuição de Ribeirão Preto.

Foram tomadas algumas medidas nas fases construtiva e de instalação do duto com a finalidade de proteger e aumentar a resistência mecânica e estrutural do sistema, e desta forma assegurar um melhor funcionamento durante a transferência dos produtos transportados pelo OSBRA. Constam como tais medidas: 
- Revestimento das paredes internas e externas com FBE (Fusion Bonded Epoxi) (Figura 15);

- Revestimento das juntas com fita de polietileno, manta termo-contráctil ou pintura epóxi (Figura 16a e 16b);

- Bombas de movimentação de produtos (Figura 17);

- Sistemas de proteção catódica;

- Sinalização das faixas de domínio do duto;

- Sistema de injeção de água de emergência em esferas de GLP;

- Sistemas de limpeza e calibragem do poliduto (scraper-traps, pigs, sump-tanks);

- Sistema de combate a incêndio em todas as bases de lançamento e de recebimento de produtos;

- Tanques e esferas de armazenamento;

- Válvulas de segurança instaladas em pontos estratégicos (Figura 18);

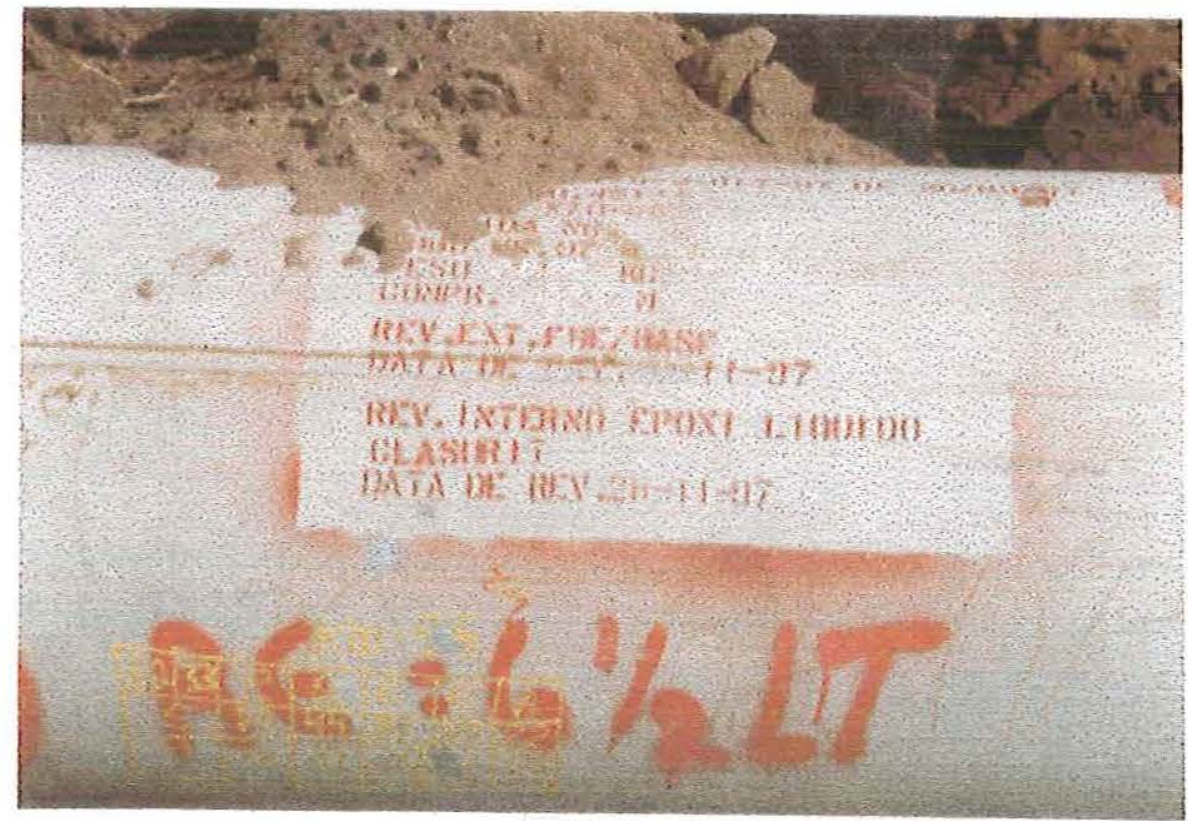

FIGURA 15: Detalhe do revestimento das paredes do duto. 


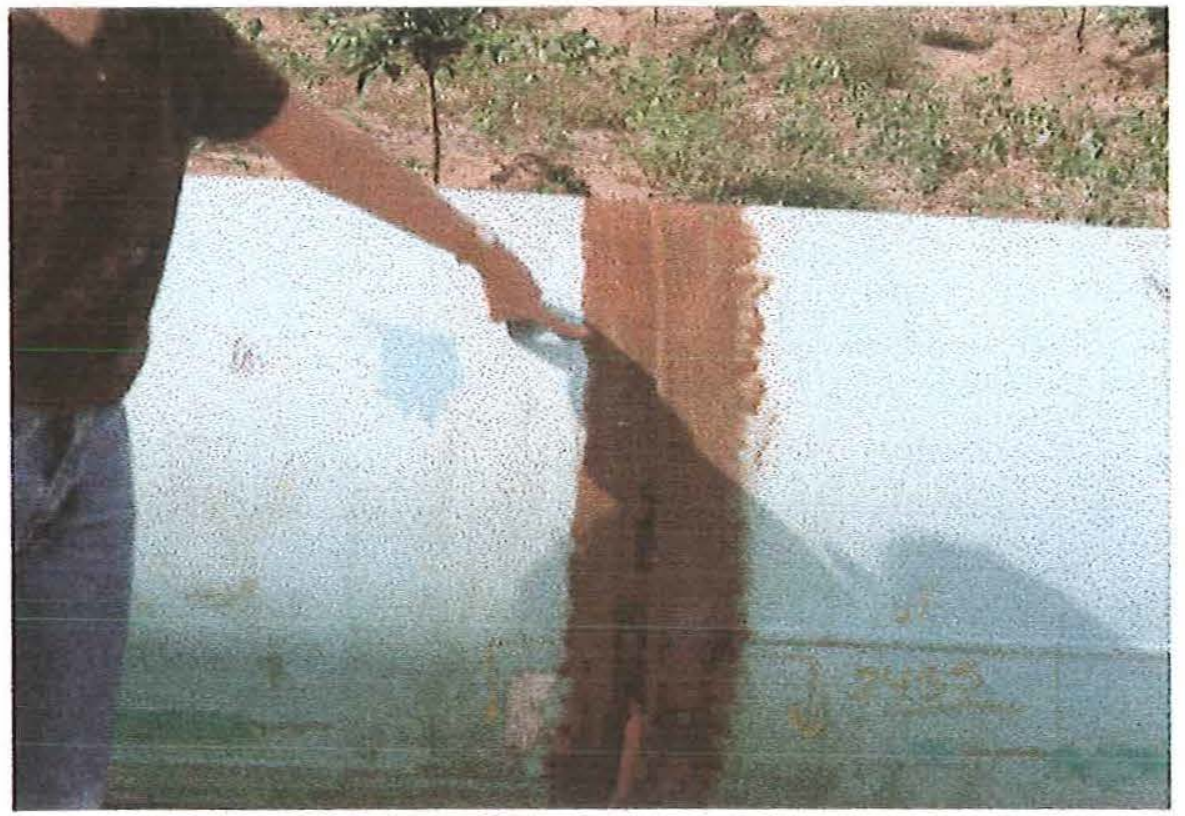

FIGURA 16a: Juntas sem revestimento.

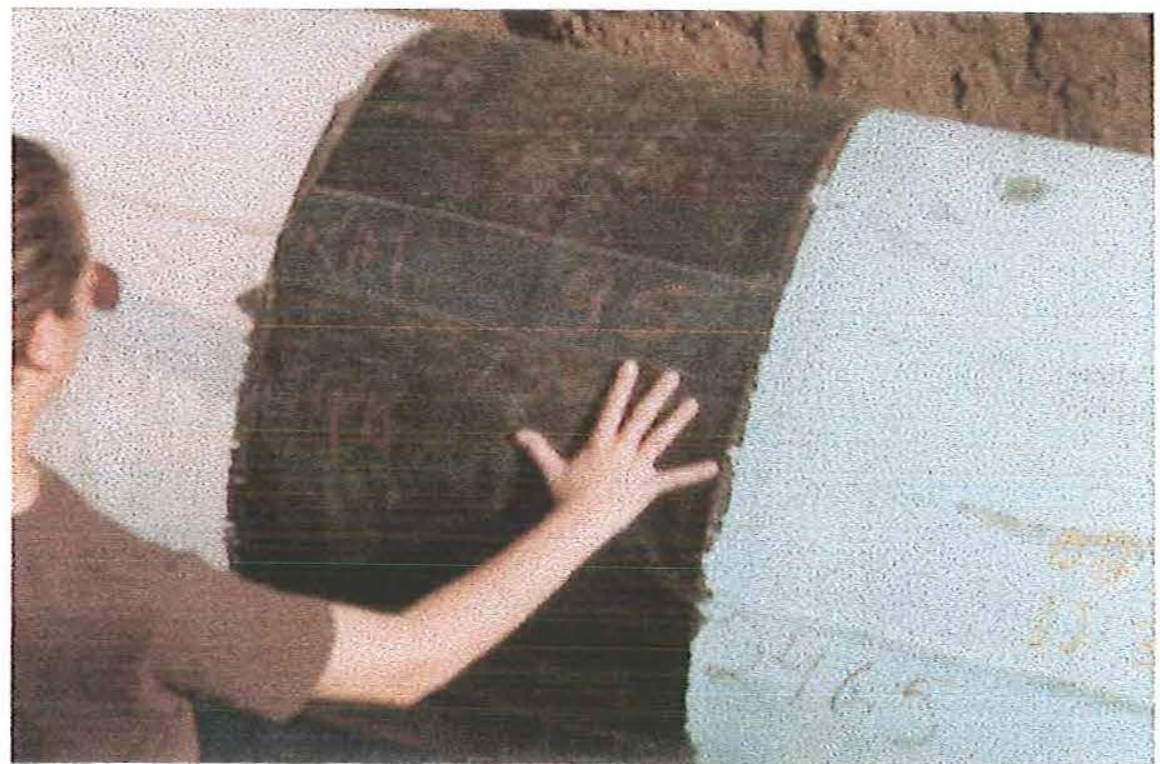

FIGURA 16b: Detalhe das juntas revestidas 


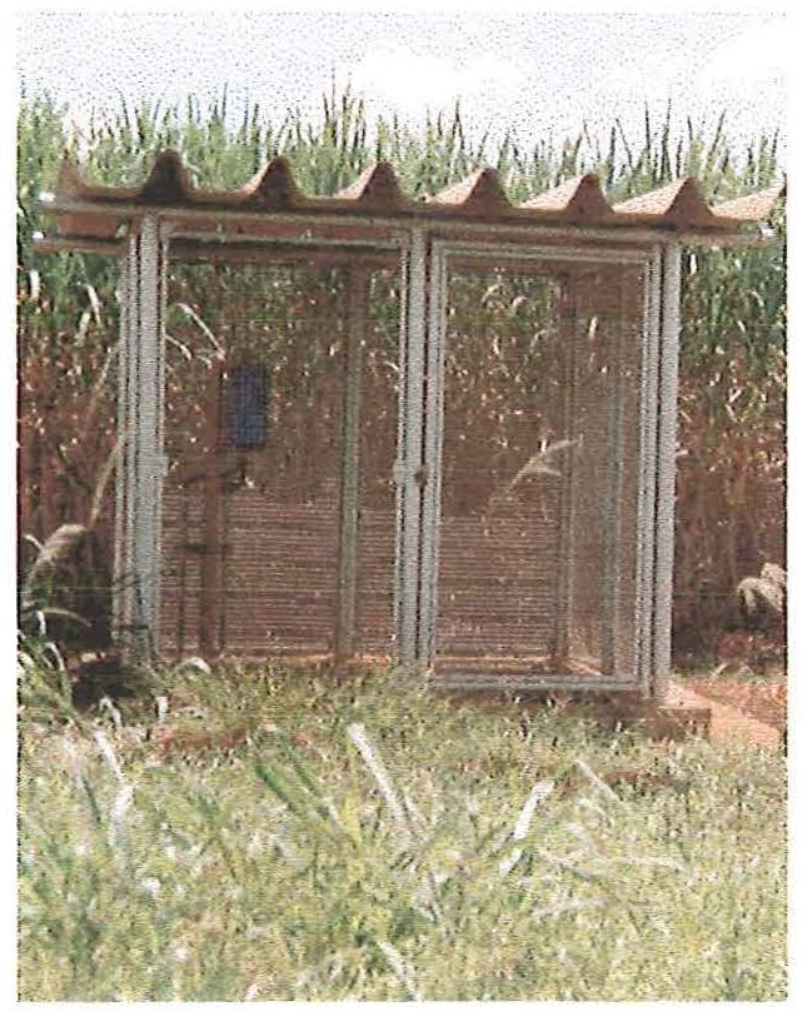

FIGURA 17: Bomba de movimentação dos produtos transportados

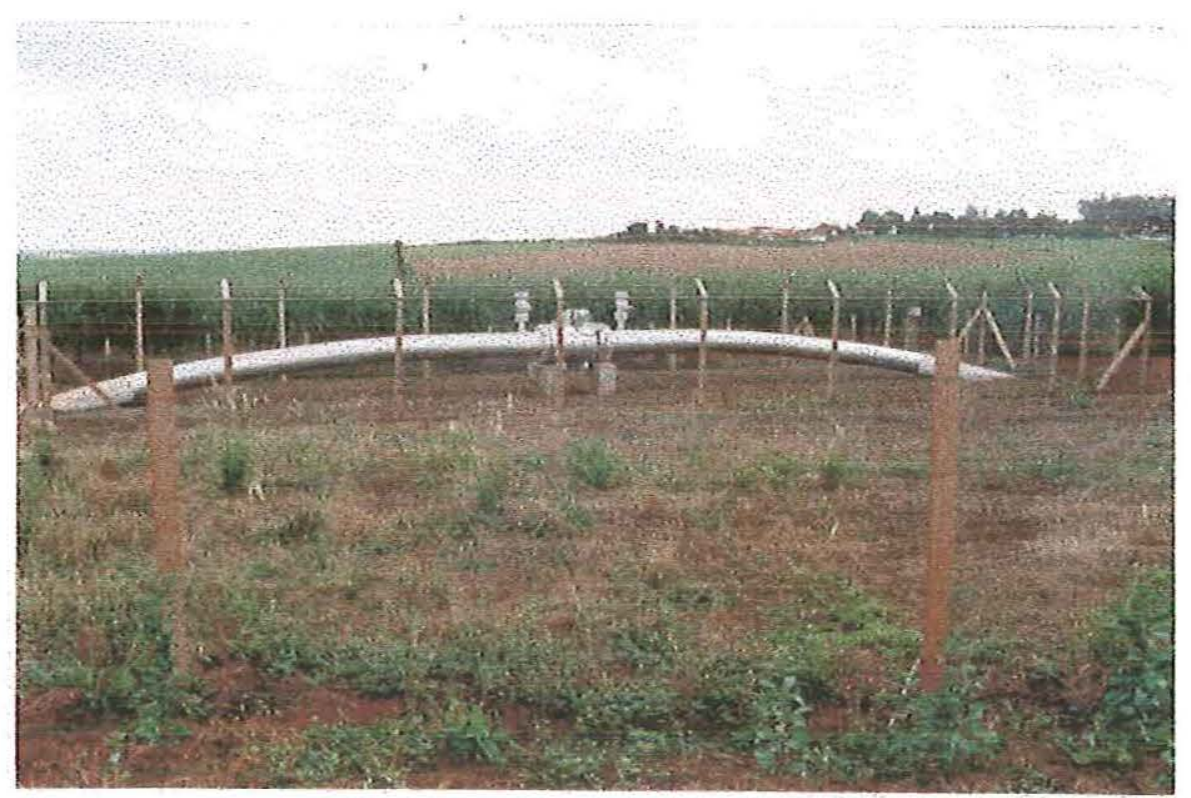

FIGURA 18: Válvula de segurança 
$\mathrm{Na}$ fase de instalação os tubos são distribuídos ao longo da pista e submetidos a curvamento, soldagem e revestimento das juntas para posteriormente serem colocados na trincheira (Figura 19 e 20), tendo início a operação de execução dos dispositivos de proteção, sinalizações, montagem de complementos e realização do teste hidrostático para detectar os possíveis vazamentos decorrentes de defeitos.

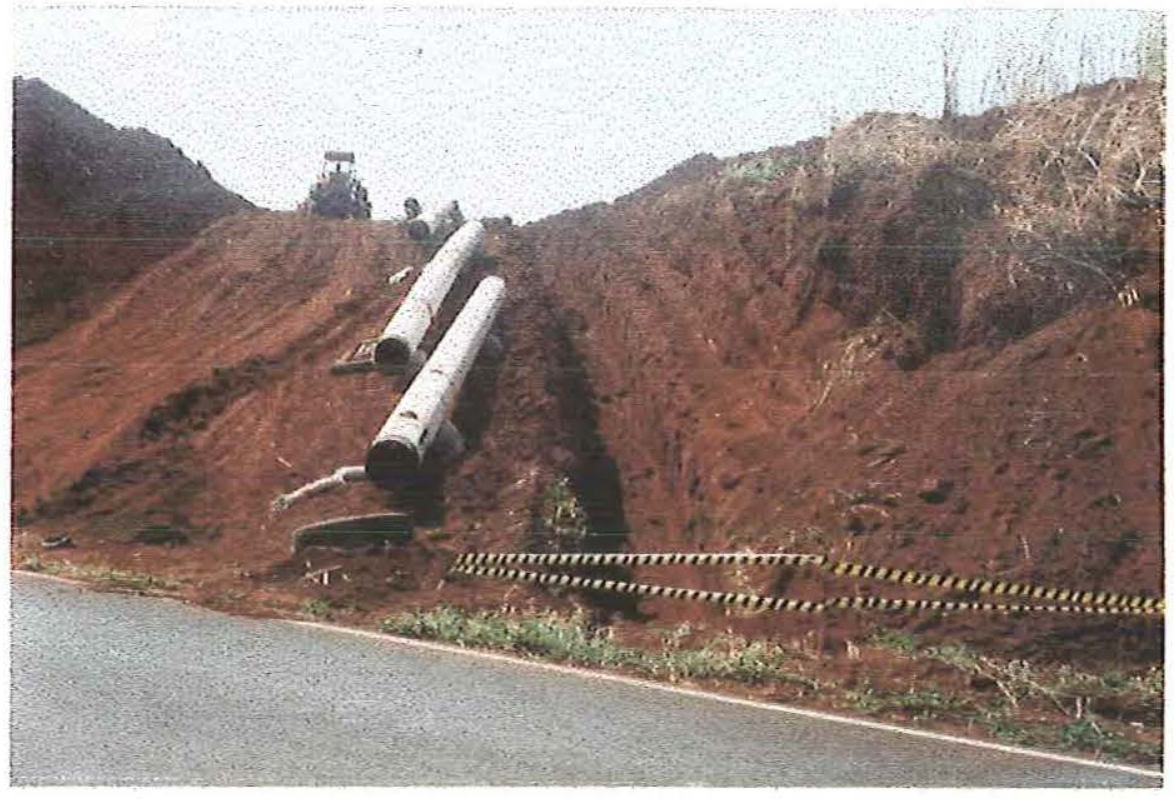

FIGURA 19: Trincheira

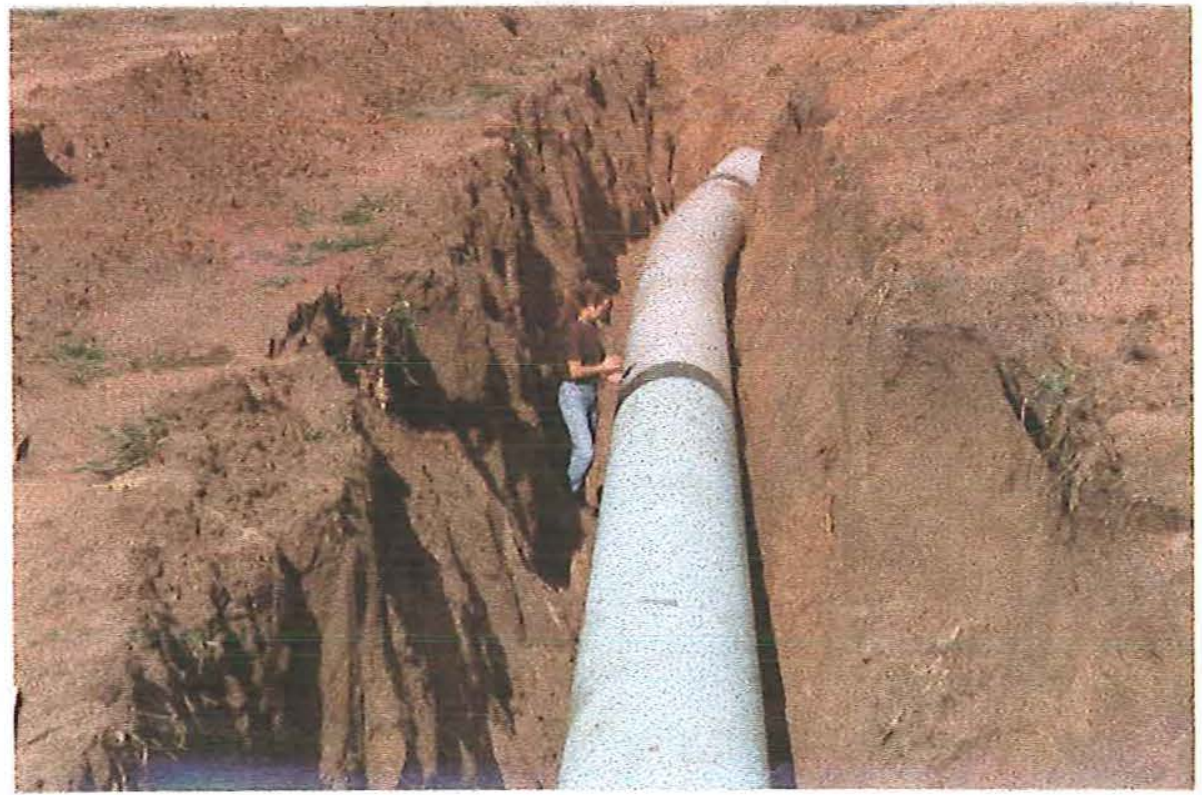

FIGURA 20: Duto instalado na trincheira 
A proteção catódica tem por objetivo aumentar o tempo de vida útil do duto através da instalação de um ânodo de sacrifício, o qual é corroído preferencialmente em relação ao material do duto. Este tipo de proteção, no entanto, não impede ou denuncia vazamentos.

Os scraper-traps são canhões que permitem o lançamento (i.e., entrada no poliduto) e o recebimento (saída) de corpos de formas esférica (esferas) ou cilíndrica (porco) denominados pigs, os quais realizam a calibragem e a limpeza do poliduto. Os sump-tanks têm como função drenar um scraper-trap antes de sua abertura para a colocação ou a retirada de um pig.

As válvulas de segurança tem por finalidade interromper a transferência dos produtos, no caso de falha no sistema ou de limpeza do poliduto.

\subsection{CARACTERÍSTICAS DOS PRODUTOS TRANSPORTADOS}

A seguir serão apresentadas as características físico-químicas, termodinâmicas e de periculosidade dos produtos transportados pelo poliduto OSBRA, que são gasolina, álcool, querosene de aviação (QAV), óleo diesel e gás liqüefeito de petróleo (GLP). Todos são transferidos na forma líquida e em uma seqüência e período de tempo definidos pela Petrobrás, de acordo com a demanda de consumo.

\subsubsection{Gás Liqüefeito de Petróleo - GLP}

O GLP é um gás liqüefeito sob pressão, composto de hidrocarbonetos de baixo peso molecular, propano e butano. Este gás, transportado sob a forma líquida, ao entrar em contato com o ambiente, isto é pressão atmosférica e temperatura ambiente, vaporiza-se rapidamente. $\mathrm{O}$ vapor, então na atmosfera, possui características inflamáveis/explosivas.

O butano e o propano possuem propriedades anestésicas e asfixiantes. Elevadas concentrações de propano agem no Sistema Nervoso Central (SNC) e quando inalados, os vapores de GLP causam tontura, dificuldades respiratórias ou perda de consciência. Em seu estado puro, o propano e o butano não possuem odor, porém quando são utilizados como combustível e quando são transportados devem ser odorizados de modo a serem detectados em caso de vazamento. O propano possui severo perigo de explosão quando exposto ao calor, chamas ou oxidantes, mas não está sujeito à combustão espontânea.

Esses gases são mais pesados do que o ar, por isso em caso de vazamento se distribuem nas zonas mais baixas do ambiente no qual se encontram, mas imediatamente sobem e evaporam. Por serem produtos inflamáveis, quando presentes em fase gasosa na 
atmosfera podem formar misturas que não são visivelmente identificadas com grande probabilidade de ignição.

TABELA 11: Propriedades físico-químicas e termodinâmicas do GLP.

\begin{tabular}{|lcc|}
\hline \multicolumn{1}{|c}{ Propriedades } & Propano & Butano \\
\hline Peso molecular médio $(\mathrm{g} / \mathrm{mol})$ & 44 & 58 \\
Densidade relativa $(\mathrm{mg} / \mathrm{L})$ & 0,51 & 0,58 \\
Viscosidade $(\mathrm{cSt})$ & $0,20-0,27$ & $0,24-0,30$ \\
Pressão de vapor $\left(\mathrm{kgf} / \mathrm{cm}^{2}\right)$ & $3,4-15,0$ & $2,0-10,1$ \\
Calor latente de vaporização $(\mathrm{Kcal} / \mathrm{Kg})$ & 85,50 & 89,00 \\
Calor de combustão $(\mathrm{Kcal} / \mathrm{Kg})$ & 11900,00 & 11800,00 \\
Ponto de ebulição $\left({ }^{\circ} \mathrm{C}\right)$ & -45 & 0 \\
\hline
\end{tabular}

TABELA 12: Dados de inflamabilidade do GLP.

\begin{tabular}{|lcc|}
\hline \multicolumn{1}{|c}{ Dados } & Propano & Butano \\
\hline Ponto de fulgor $\left({ }^{\circ} \mathrm{C}\right)$ & $-68,8$ & $-104,8$ \\
Ponto de auto-ignição $\left({ }^{\circ} \mathrm{C}\right)$ & 450,0 & 405,0 \\
Limites de inflamabilidade & & \\
Inferior (\%) & 2,3 & 1,9 \\
Superior (\%) & 9,5 & 8,5 \\
\hline
\end{tabular}

\subsubsection{Gasolina}

A gasolina é constituída de uma mistura de hidrocarbonetos parafínicos, naftalênicos, olefínicos e aromáticos cuja faixa de destilação varia de 30 a $220^{\circ} \mathrm{C}$. A gasolina pode causar vários tipos de distúrbios à saúde e aos componentes do meio ambiente. Se as concentrações presentes no ar forem relativamente altas de modo a reduzir o conteúdo de oxigênio abaixo da quantidade necessária para a vida, os componentes agirão como um asfixiante.

A gasolina é perigosa quando exposta ao calor ou a chama e pode reagir violentamente com materiais oxidantes, causando incêndios e/ou explosões.

- Propriedades Físico-Químicas e Termodinâmicas

- Peso molecular médio: $0,87 \mathrm{~g} / \mathrm{mol}$ 
- Densidade relativa: $0,72 \mathrm{mg} / \mathrm{L}$

- Viscosidade: 0,704 a $0,903 \mathrm{cSt}$

- Pressão de vapor: 0,40 a $0,70\left(\mathrm{Kgf} / \mathrm{cm}^{2}\right)$

- Calor latente de vaporização: $86,89 \mathrm{kcal} / \mathrm{kg}$

- Calor de combustão: 11483,92 kcal/kg

- Ponto de ebulição: 65 a $200{ }^{\circ} \mathrm{C}$

- Dados de Inflamabilidade

- Ponto de fulgor: -45 a $-20^{\circ} \mathrm{C}$

- Ponto de auto-ignição: 280 a $456{ }^{\circ} \mathrm{C}$

- Limites de inflamabilidade: 1,4 a 7,6\% vol

\subsection{3. Álcool Anidro e Hidratado}

O álcool é rapidamente oxidado em contato com o dióxido de carbono $\left(\mathrm{CO}_{2}\right)$ e com a água. A exposição a uma concentração de 5.000 a 10.000 ppm provoca irritação nos olhos e na membrana mucosa da traquéia. Caso continue nessa faixa de concentração provoca tontura e sonolência. Concentrações abaixo de 1.000 ppm geralmente não produzem sinais de intoxicação. Dosagens elevadas podem causar envenenamento e atingir o sistema nervoso central.

O álcool etílico é perigoso quando exposto ao calor ou a chama, podendo reagir violentamente com substâncias oxidantes e os riscos associados são relativos a incêndios e explosões.

Álcool Hidratado

- Propriedades físico-químicas e termodinâmicas

- Peso molecular médio: $46 \mathrm{~g} / \mathrm{mol}$

- Densidade relativa: $0,79 \mathrm{mg} / \mathrm{L}$

- Viscosidade: 1,55 a $1,10 \mathrm{cSt}$

- Pressão de vapor: 0,068 a 0,071 (Kgf/ $\left./ \mathrm{cm}^{2}\right)$

- Calor latente de vaporização: $203,973 \mathrm{kcal} / \mathrm{kg}$

- Calor de combustão: 7095,33 kcal/kg

- Ponto de ebulição: $78,32{ }^{\circ} \mathrm{C}$

- Dados de Inflamabilidade

- Ponto de fulgor: $12,08^{\circ} \mathrm{C}$ 
- Ponto de auto-ignição: $423,00{ }^{\circ} \mathrm{C}$

- Limites de inflamabilidade: 3,3 a $19 \%$ vol

Álcool Anidro

- Propriedades físico-químicas e termodinâmicas

- Peso molecular médio: $46 \mathrm{~g} / \mathrm{mol}$

- Densidade relativa: $0,79 \mathrm{mg} / \mathrm{L}$

- Viscosidade: 1,55 a $1,10 \mathrm{cSt}$

- Pressão de vapor: 0,068 a 0,071 (Kgf/cm²)

- Calor latente de vaporização: 203,973 kcal/kg

- Calor de combustão: 7095,33 kcal/kg

- Ponto de ebulição: $78,32{ }^{\circ} \mathrm{C}$

- Dados de Inflamabilidade

- Ponto de fulgor: $12,08^{\circ} \mathrm{C}$

- Ponto de auto-ignição: $423,00{ }^{\circ} \mathrm{C}$

- Limites de inflamabilidade: 3,7 a $13,7 \%$ vol

\subsection{4. Óleo Diesel}

O óleo diesel possui maior peso molecular do que a gasolina devido a presença de compostos com maior número de carbonos em sua estrutura molecular. Essa propriedade juntamente com a menor quantidade de hidrocarbonetos aromáticos o torna mais denso e menos solúvel do que a gasolina.

Apresenta risco de incêndio e/ou explosão em condições tais como temperatura e pressões elevadas, quando exposto ao calor, a chama ou a oxidantes.

- Propriedades físico-químicas e termodinâmicas

- Peso molecular médio: $195 \mathrm{~g} / \mathrm{mol}$

- Densidade relativa: $0,83 \mathrm{mg} / \mathrm{L}$

- Viscosidade: 6,00 a 9,60 cSt

- Pressão de vapor: 0,08 a $0,15\left(\mathrm{Kgf} / \mathrm{cm}^{2}\right)$

- Calor latente de vaporização: $130,20 \mathrm{kcal} / \mathrm{kg}$

- Calor de combustão: $10601,43 \mathrm{kcal} / \mathrm{kg}$

- Ponto de ebulição: 155 a $350{ }^{\circ} \mathrm{C}$ 
- Dados de Inflamabilidade

- Ponto de fulgor: ambiente ${ }^{\circ} \mathrm{C}$

- Ponto de auto-ignição: $257^{\circ} \mathrm{C}$

- Limites de inflamabilidade: dados não disponíveis \% vol

\subsubsection{Querosene de Aviação - QAV}

A querosene de aviação consiste de uma mistura de hidrocarbonetos líquidos e possui coloração amarela. É altamente tóxica por via intravenosa. A inalação de vapores com elevadas concentrações pode causar dor de cabeça e letargia. A ingestão pode causar irritação do estômago e intestinos, com náusea e vômitos.

Possui risco de incêndio e/ou explosão quando exposta ao calor ou a chama e pode reagir com materiais oxidantes.

- Propriedades físico-químicas e termodinâmicas

- Peso molecular médio: $144 \mathrm{~g} / \mathrm{mol}$

- Densidade relativa: 0,76 a $0,822 \mathrm{mg} / \mathrm{L}$

- Viscosidade: 2,4 a 1,70 cSt

- Pressão de vapor: $0,00\left(\mathrm{Kgf} / \mathrm{cm}^{2}\right)$

- Calor latente de vaporização: $272,24 \mathrm{kcal} / \mathrm{kg}$

- Calor de combustão: 10867,36 kcal/kg

- Ponto de ebulição: 204 a $300{ }^{\circ} \mathrm{C}$

- Dados de Inflamabilidade

- Ponto de fulgor: 40 a $74^{\circ} \mathrm{C}$

- Ponto de auto-ignição: $210^{\circ} \mathrm{C}$

- Limites de inflamabilidade: 0,7 a 5,0 \% vol

\subsection{CARACTERÍSTICAS DO MEIO FÍSICO}

\subsubsection{Geologia da Área}

A geologia da área é representada por litologias com idades variando entre paleozóicas até cenozóicas conforme a coluna estratigráfica mostrada na Tabela 13.

A distribuição dessas rochas pode ser observada no Mapa Geológico 2 (ANEXO $5)$. 
TABELA 13: Coluna estratigráfica da área estudada. Modificada de DAEE (1975) e PETRI \& FÚLFARO (1982).

\begin{tabular}{|c|c|c|c|c|c|}
\hline \multicolumn{2}{|c|}{ CRONOESTRATIGRAFIA } & \multicolumn{4}{|r|}{ LITOESTRATIGRAFIA } \\
\hline ERA & SISTEMA & GRUPO & FORMAÇĀO & SÍMBOLO & CARACTERÍSTICAS \\
\hline \multirow{2}{*}{ 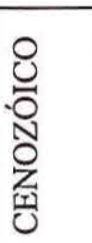 } & QUATERNÁRIO & & & Q & $\begin{array}{l}\text { Aluviões, eluviões e areias mal consolidadas. } \\
\text { Alternância desde cascalhos até argilas. }\end{array}$ \\
\hline & TERCIÁRIO & & & & $\begin{array}{l}\text { Terraços. Arenitos vermelho tijolo, variação desde conglomerado a } \\
\text { lamitos com estratratificação. planoparalela. }\end{array}$ \\
\hline \multirow{3}{*}{ 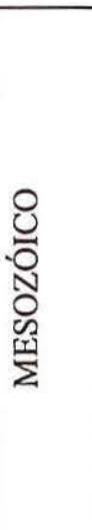 } & CRETÁCEO & \multirow{3}{*}{$\begin{array}{l}\text { SÃO } \\
\text { BENTO }\end{array}$} & $\begin{array}{l}\text { SERRA } \\
\text { GERAL }\end{array}$ & KJsg & $\begin{array}{l}\text { Derrames basálticos e intrusões diabásicas. } \\
\text { Nos basaltos ocorrem arenitos intertrapianos. }\end{array}$ \\
\hline & JURÁSSICO & & BOTUCATU & $\mathrm{KJb}$ & $\begin{array}{l}\text { Arenito fino a médio, homogêneo, de origem eólica com estratificação } \\
\text { cruzada, de porte médio e grande, percentagem de finos }<10 \% \text {. }\end{array}$ \\
\hline & TRIÁSSICO & & PIRAMBÓIA & Tjp & $\begin{array}{l}\text { Arenitos argilosos com porcentagem de finos entre } 5 \% \text { e } 20 \% \text {. } \\
\text { Lâminas de argila e silte. Parte inferior com maior teor de finos. } \\
\text { Estratificação cruzada e estrutura maciça de origem flúvio lacustre. }\end{array}$ \\
\hline 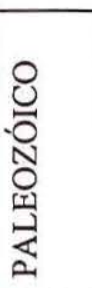 & PERMIANO & $\begin{array}{l}\text { PASSA } \\
\text { DOIS }\end{array}$ & CORUMBATAÍ & $\mathrm{P}$ & $\begin{array}{l}\text { Siltitos e argilitos roxos, cinzas, ou avermelhados, com intercalações de } \\
\text { bancos carbonáticos, e camadas de arenitos finos. } \\
\text { Ritmitos sob a forma de alternância de lâminas de siltito e argilito. }\end{array}$ \\
\hline
\end{tabular}




\subsubsection{Formação Corumbataí}

Segundo IPT (1981), no Estado de São Paulo a Formação Corumbataí, onde não interrompida por sills de diabásio ou falhas, aflora continuamente do divisor de águas dos rios Tietê e Piracicaba para norte, até próximo ao limite com Minas Gerais. A Formação apresenta-se com espessura geralmente inferior a 150 metros, que se reduz para o norte, até próximo ao limite com Minas Gerais, recobrindo-se em discordância pela Formação Pirambóia.

Na bacia hidrográfica do rio Corumbataí, região-tipo onde ela tem sido mais estudada, a Formação Corumbataí em sua parte inferior apresenta siltitos, argilitos e folhelhos cinzentos a roxo acinzentados, podendo possuir cimento carbonático. Segue-se uma sucessão de camadas siltosas, ritmicamente alternadas com lâminas ou delgadas camadas cuja litologia varia entre argilosa e arenosa fina, tanto vertical quanto horizontalmente. As cores vermelhas e arroxeadas passam a predominar nas partes média e superior da Formação, onde também se apresentam lentes e bancos calcários com até cerca de meio metro de espessura.

Na área estudada, a Formação Corumbataí ocupa uma área significativa (Mapa Geológico 2 - ANEXO 5), e é constituída por uma sucessão de camadas sílticas e argilosas, de cor arroxeada e creme, apresentando desagregação em pastilhas (Figuras 21 e 22).

Em mapeamentos geológicos anteriores, esta unidade foi identificada como pertencente à Formação Pirambóia, por apresentar camadas pouco espessas de material argiloso compacto, de cor avermelhada associado à um material de cobertura areno-argilosa avermelhado também interpretado como pertencente à Formação Pirambóia (Mapa Geológico 1 - ANEXO 4). No entanto, nos afloramentos situados próximo ao Rio MogiGuaçu, bem como nas bacias do Ribeirão da Corrente, Rio São Vicente e do Córrego do Barreira, pode-se notar a presença típica da Formação Corumbataí, por vezes recoberta por material areno-argiloso retrabalhado (Figura 23). 


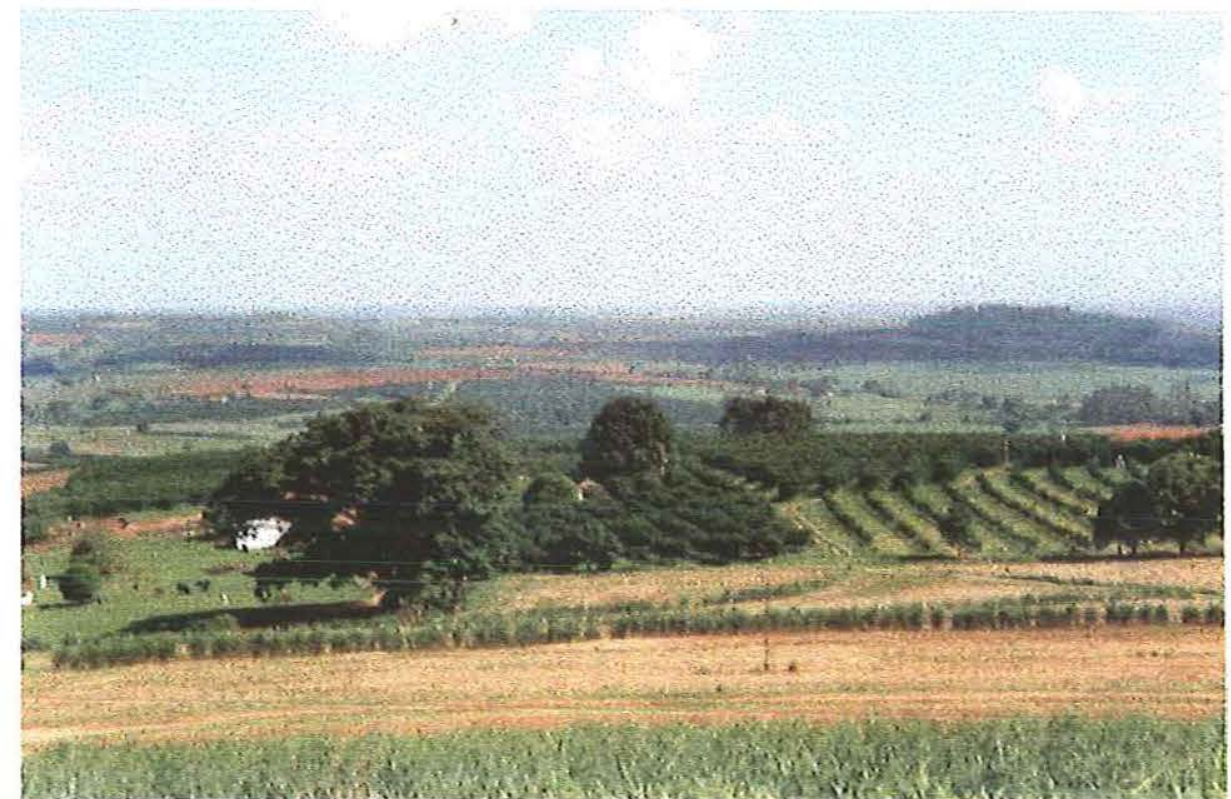

FIGURA 21: Vista do alinhamento do duto sobre a Formação Corumbataí.

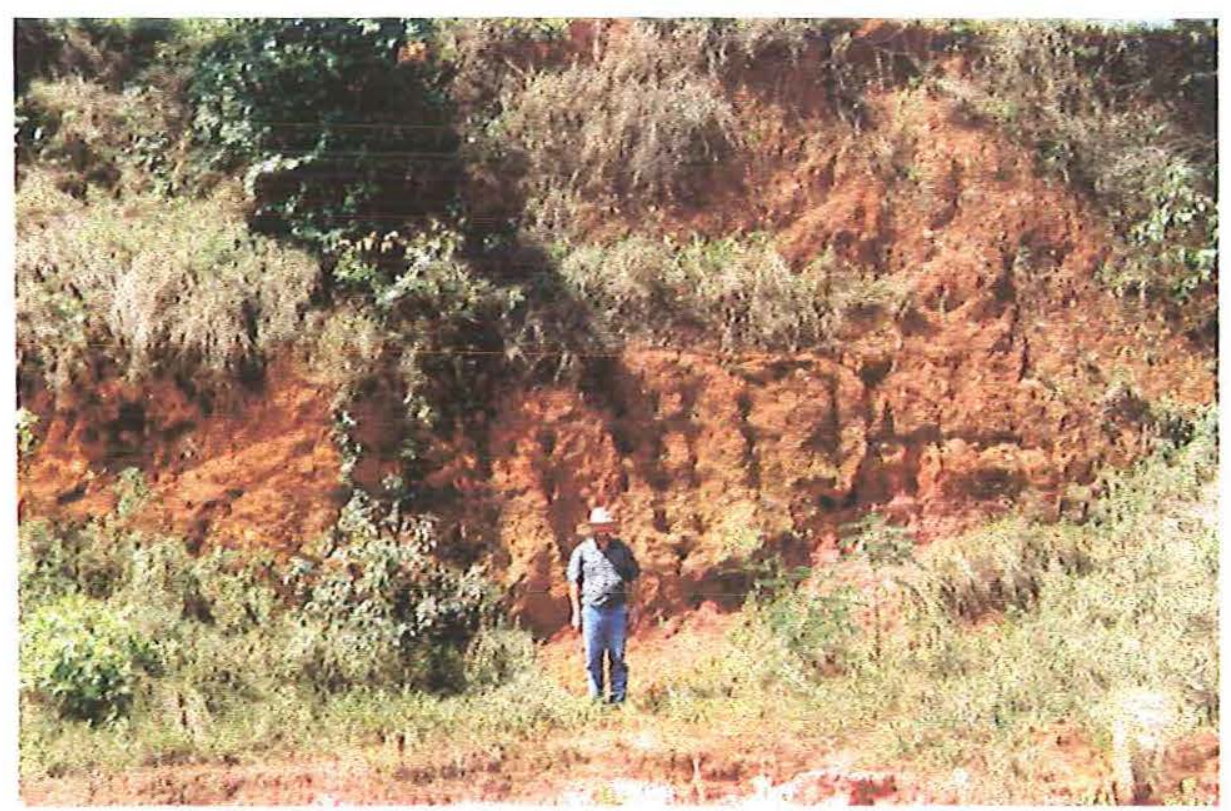

FIGURA 22: Camadas sílticas e argilosas da Formação Corumbataí em contato com material transportado. 


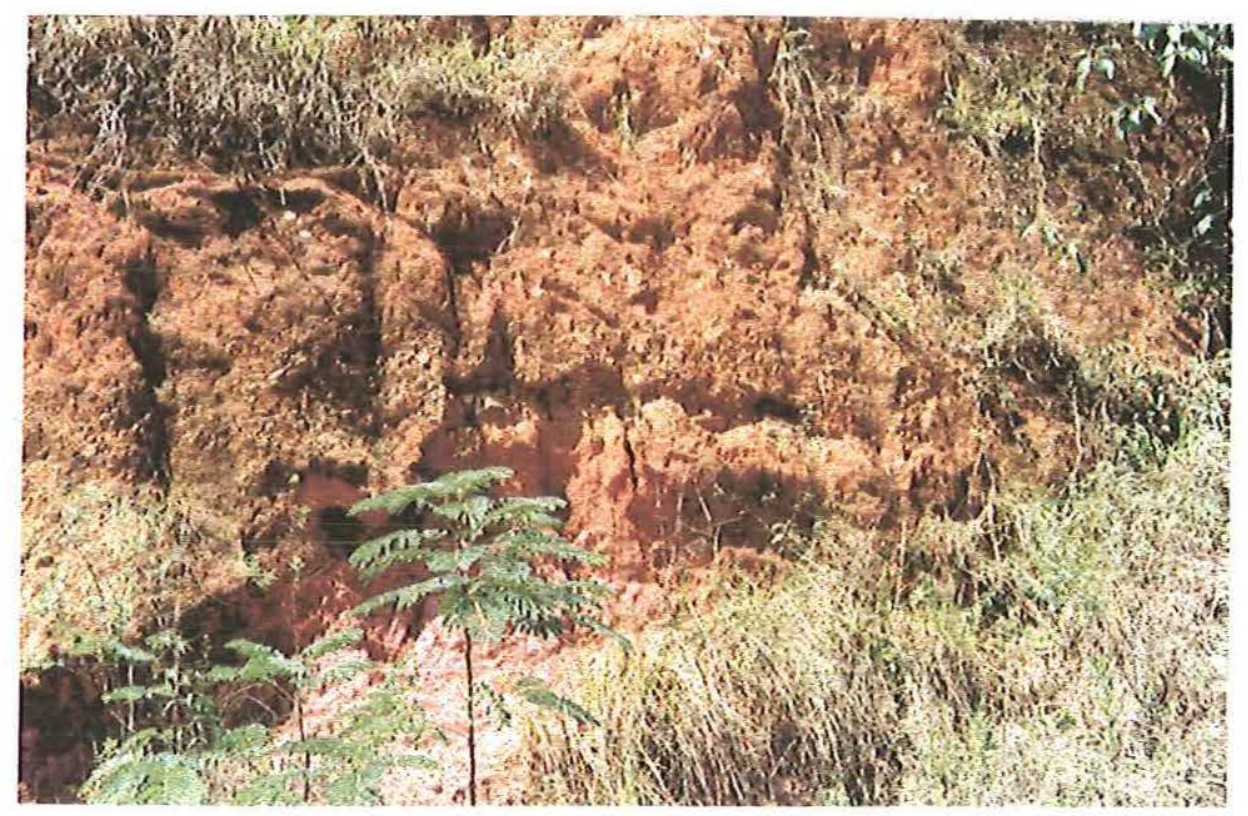

FIGURA 23: Detalhe da Formação Corumbataí recoberta por material inconsolidado areno-argiloso retrabalhado.

\subsubsection{Formação Pirambóia}

Segundo IPT (1981), a Formação Pirambóia caracteriza-se litologicamente por uma sucessão de camadas arenosas, mais comumente vermelhas, de granulação fina a média, possuindo fração argilosa maior na parte inferior do que na superior, onde normalmente ocorrem arenitos grossos, conglomeráticos. Acrescenta ainda que a Formação pode atingir até 270 metros de espessura em alguns locais como na região de Anhembi - São Pedro.

$\mathrm{Na}$ área estudada, a Formação caracteriza-se por arenitos de textura média a fina, de cor avermelhada. Em alguns locais apresenta maiores quantidades de finos (silte e argila). Ocupa regiões pouco extensas da área estudada, estando em sua maior parte, presente nas bacias de drenagem dos rios Bebedouro e Tamanduá, como pode ser verificado no Mapa Geológico 2 (ANEXO 5) 


\subsubsection{Formação Botucatu}

A Formação Botucatu é freqüentemente descrita na literatura (FÚLFARO et al, 1980; SOARES et al, 1971; IPT, 1980) como uma unidade constituída por arenitos de granulação fina à média, uniformes, localmente composto por corpos lenticulares de arenitos heterogêneos, de granulação média à grossa, passando a arenitos conglomeráticos sobretudo nas partes baixas do pacote. Segundo IPT, (1981) a espessura total da Formação em exposições, varia em São Paulo entre meia e uma centena de metros, sabe-se porém através de sondagens que a Formação Botucatu pode ultrapassar 200 metros de espessura.

Na região, a Formação Botucatu ocupa uma vasta extensão como pode ser observado no Mapa Geológico 2 (ANEXO 5). A Formação é constituída por arenitos de textura fina a média, com grãos bem arredondados (Figura 24).

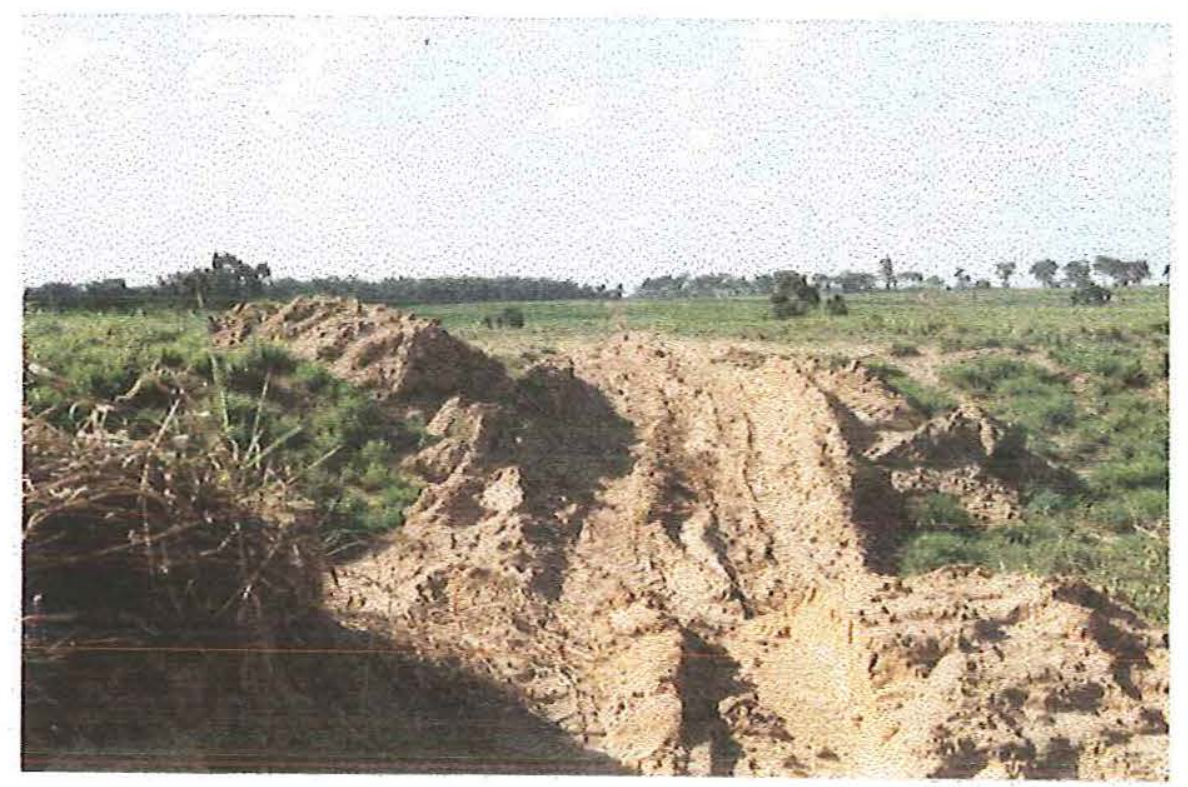

FIGURA 24: Formação Botucatu

\subsubsection{Formação Serra Geral}

As eruptivas da Formação Serra Geral são constituídas por derrames basálticos entre os quais se intercalam arenitos pertencentes à Formação Botucatu, por vezes associados à corpos intrusivos de diabásio constituindo sobretudo diques e sills (IPT, 1981). 
A Formação Serra Geral ocorre na região como derrames basálticos e como intrusões de diabásio, ocupando extensas áreas da região como está registrado no Mapa Geológico 2 (ANEXO 5). Pode-se notar, através do Perfil Geológico-Geotécnico 2 (ANEXO 9), que em alguns locais a Formação pode atingir espessuras de aproximadamente 180 metros

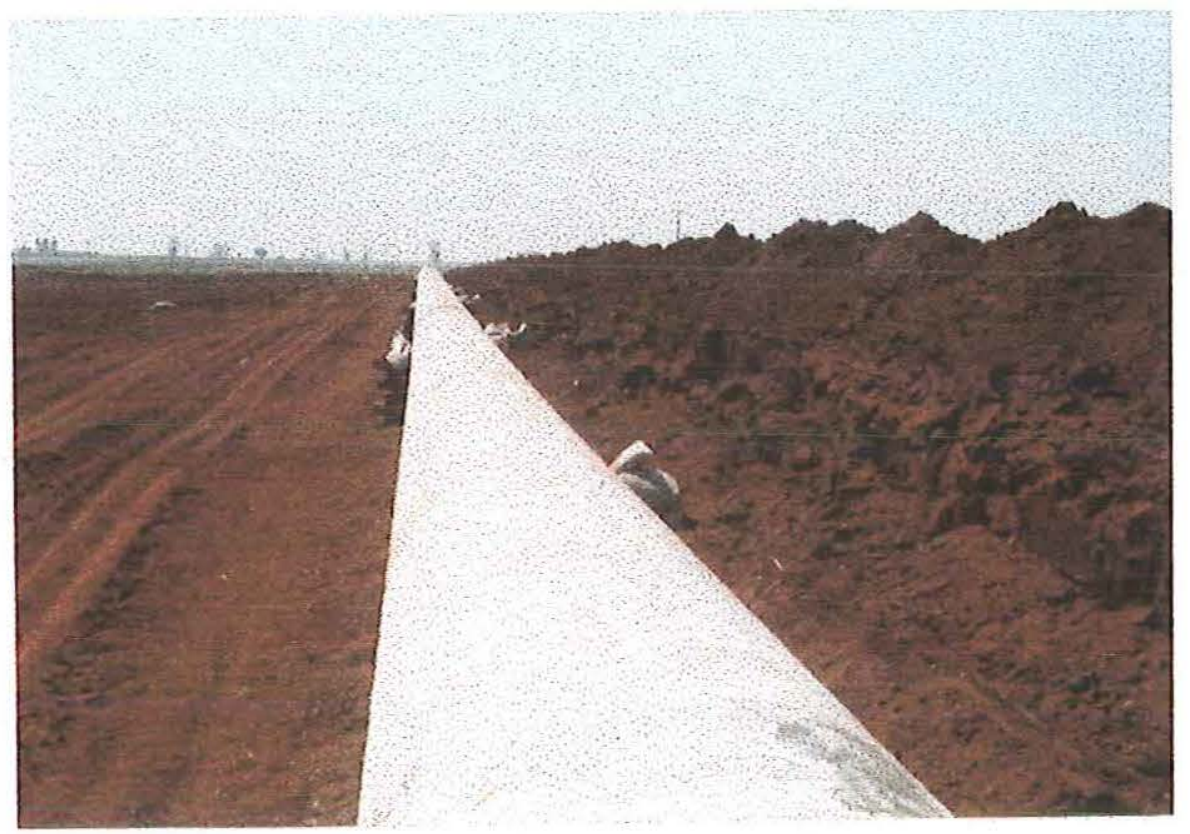

FIGURA 25: Formação Serra Geral.

\subsubsection{Materiais Inconsolidados}

Os materiais inconsolidados encontrados na região são produtos das alterações dos materiais rochosos arenosos (formações Botucatu e Pirambóia), sílticos e argilosos (Formação Corumbataí) e magmáticos básicos (diabásios e basaltos da Formação Serra Geral), sendo portanto texturalmente arenosos e argilosos. Devido a evolução geomorfológica houve misturas entre esses dois tipos básicos surgindo materiais mistos contendo porcentagens que podem chegar próximo a 50\% de areias e $50 \%$ de argilas.

A distribuição em área desses materiais pode ser observada no Mapa de Materiais Inconsolidados (ANEXO 6). 


\subsubsection{Aluviões}

São materiais constituídos por alternância de conglomerados, areias mal consolidadas à argilas, de coloração clara, encontrados nas bacias dos Rios Mogi-Guaçu e Claro.

\subsubsection{Materiais Hidromórficos}

Esses materiais ocorrem em várzeas e fundos de vale, sempre próximos ao nível de água ( $<1$ metro), estando permanentemente ou sazonalmente saturado. São constituídos por areias, argilas ou siltes, geralmente de coloração clara.

São encontrados nas bacias de inundação do Ribeirão do Tamanduá, Rio Bebedouro, Córrego da Onça, Córrego do Jequitiba, e Córrego da Sucuri.

\subsubsection{Materiais Residuais Arenosos}

Estes materiais são encontrados em grande parte da região (ANEXO 6), são originados da alteração dos arenitos das formações Botucatu e Pirambóia, apresentam alta homogeneidade em perfil quanto a textura e mineralogia e baixa coesão. A espessura destes materiais normalmente é superior a $5 \mathrm{~m}$ inferior a $20 \mathrm{~m}$, ocorrendo predominantemente em áreas planas. $\mathrm{O}$ fluxo de água nestes materiais é muito rápido e a profundidade do nível de água é, na maior parte do ano, superior a $8 \mathrm{~m}$. São materiais que apresentam alto potencial a erodibilidade e alta condutividade, $\mathrm{K}=10^{-2}$ a $10^{-3} \mathrm{~cm} / \mathrm{s}$. Segundo Zuquette (1993) a fração areia é superior a $90 \%$, com índice de vazios maior do que 1 .

\subsubsection{Materiais Residuais Argilosos}

Estes materiais ocupam extensas áreas na região, são tipicamente finos com predomínio da fração argilosa e siltosa, apresentam espessuras que variam de alguns centímetros até 20 metros. Possuem elevado índice de vazios e condutividade hidráulica também elevada na ordem de $10^{-3}$ a $10^{-4} \mathrm{~cm} / \mathrm{s}$, devido à tendência de formar agregados.

\subsubsection{Materiais Mistos}

São enquadrados neste grupo os materiais que apresentam contribuições devido ao retrabalhamento do mesmo ou de outros próximos, descaracterizando o perfil de alteração, como totalmente residual. Estes são encontrados em encostas, desde íngremes até suaves, em muitos locais é possível observar uma descontinuidade representada por linha de seixos, ou por restos de materiais distribuídos na porção superior do perfil. 


\subsection{Argilosos}

Texturalmente, estes materiais apresentam-se predominantemente argilosas na parte retrabalhada e argilosa-siltosa na porção residual. A espessura desses pacotes varia de 2 a 25 metros, e a parte retrabalhada chega até $10 \mathrm{~m}$. Apresentam alto índice de vazios, maior que 1 e condutividade hidráulica variando entre $10^{-2}$ a $10^{-3} \mathrm{~cm} / \mathrm{s}$.

\subsection{Arenosos e Argilosos}

Este pacote típico é constituído na parte superior por uma mistura de materiais arenosos com argilosos originados do retrabalhamento dos materiais argilosos nas porções topograficamente mais elevadas. As espessuras destes pacotes são superiores a $10 \mathrm{~m}$, mineralógicamente são constituídos por quartzo, caulinita e outros óxidos.

A porção inferior é predominantemente arenosa, residual dos arenitos das formações Botucatu e Pirambóia. Devido a parte superior apresentar porcentagens de argila, são ocupados intensamente por agropecuária e são bastante erodíveis. Assim como o argiloso, estes materiais possuem alto índice de vazios, maior que 1 e condutividade hidráulica variando entre $10^{-2}$ a $10^{-3} \mathrm{~cm} / \mathrm{s}$ (ZUQUETTE, 1993).

A distribuição das litologias e dos materiais inconsolidados ao longo do corte do trecho estudado, está representada no Perfil Geológico-Geotécnico 2. Este perfil foi elaborado com base no Mapa Topográfico (ANEXO 3) e escalas horizontal de 1:100.000 e vertical de 1:2.000, portanto com uma sobrelevação de 50 vezes.

As zonas com diferentes características geológico-geotécnicas estão representadas na Carta de Zoneamento Geológico-Geotécnico (ANEXO 10).

Para a confecção desta Carta foi necessário adotar índices correspondentes às classes de atributos representadas em cada mapa, como ilustrado nas tabelas a seguir:

TABELA 14: Índices adotados para tipo de material inconsolidado

\begin{tabular}{|c|l|}
\hline Indices & \multicolumn{1}{|c|}{ Tipo de Material Inconsolidado } \\
\hline A & Material residual argiloso \\
\hline B & Material residual arenoso \\
\hline C & Material misto areno-argiloso \\
\hline D & Material misto argiloso \\
\hline E & Material hidromórfico \\
\hline F & Aluviões \\
\hline
\end{tabular}


TABELA 15: Índices adotados para tipos rochosos

\begin{tabular}{|c|l|}
\hline Índices & \multicolumn{1}{|c|}{ Geologia } \\
\hline 1 & Formação Serra Geral \\
\hline 2 & Formação Botucatu \\
\hline 3 & Formação Pirambóia \\
\hline 4 & Formação Corumbataí \\
\hline
\end{tabular}

TABELA 16: Índices adotados para classes de profundidade de substrato rochoso

\begin{tabular}{|c|c|}
\hline Índices & Classes de Profundidade do Substrato Rochoso \\
\hline 1 & $<2$ metros \\
\hline 2 & $2-5$ metros \\
\hline 3 & $2-10$ metros \\
\hline 4 & $5-10$ metros \\
\hline 5 & $>10$ metros \\
\hline
\end{tabular}

TABELA 17: Índices adotados para classes de nível de água

\begin{tabular}{|c|c|}
\hline Índices & Classes de nível de água \\
\hline 1 & $0-2$ metros \\
\hline 2 & $2-5$ metros \\
\hline 3 & $5-10$ metros \\
\hline 4 & $10-20$ metros \\
\hline 5 & NA situado em meio fraturado \\
\hline
\end{tabular}

Cabe ressaltar que esses índices não correspondem à pesos atribuídos à essas unidades, mas à uma forma de nomenclatura adotada para facilitar a visualização e a caracterização das unidades resultantes desse cruzamento, as quais foram classificadas da seguinte maneira: 


\section{$\mathcal{E}_{i j k}$}

onde:

$\mathcal{E}=$ tipo de material inconsolidado;

$\mathrm{i}=$ geologia;

$\mathrm{j}=$ profundidade do substrato rochoso;

k = nível de água

A Tabela abaixo mostra três exemplos da classificação das unidades de zoneamento:

TABELA 18: Esquema de classificação das unidades de zoneamento.

\begin{tabular}{|c|l|}
\hline$\varepsilon_{i j k}$ & \multicolumn{1}{|c|}{ Unidade de Zoneamento } \\
\hline A125 & $\begin{array}{l}\text { Material residual argiloso derivado da Fm Serra Geral, com prof. Entre 2 a } 5 \\
\text { metros, e zona saturada situada em meio fraturado. }\end{array}$ \\
\hline B354 & $\begin{array}{l}\text { Material residual arenoso derivado da Fm Pirambóia, com prof. > 10m, e nível } \\
\text { de água situado entre 10 a 20 metros. }\end{array}$ \\
\hline E311 & $\begin{array}{l}\text { Material hidromórfico associado à Fm Pirambóia, com prof. < que 2 metros, e } \\
\text { nível de água < que 2 metros. }\end{array}$ \\
\hline
\end{tabular}

\subsubsection{Clima}

Segundo dados do DAEE (1975), o índice de precipitação média da região é da ordem de $1350 \mathrm{~mm} / \mathrm{ano}$. O período chuvoso está compreendido entre outubro e março, com temperaturas médias de 22 a $26^{\circ} \mathrm{C}$ e umidade relativa do ar variando entre 50 a $80 \%$. No período seco, de abril a setembro, as temperaturas médias permanecem em torno de 13 a $16^{\circ} \mathrm{C}$ com umidade relativa variando de 20 a $60 \%$. 


\subsection{4. Águas}

\subsubsection{Superficiais}

A área é banhada pelas bacias hidrográficas dos rios Mogi-Guaçu e Pardo, Mapa da Bacias Hidrográficas Interceptadas pelo Duto (Anexo 1). Destas bacias hidrográficas, apenas os seus distributários principais, Rio Bebedouro e Ribeirão do Tamanduá, e os de menor extensão ocorrem na faixa de influência imediata do duto Mapa da Faixa de Influência (Anexo 2).

TABELA 19: Características das 2 principais bacias hidrográficas interceptados pelo duto.

Fonte: Modificado de DAEE (1975).

\begin{tabular}{|lcccc|}
\hline \multicolumn{1}{|c}{ Rios } & $\begin{array}{c}\text { Área } \\
\text { Superficial }\left(\mathrm{Km}^{2}\right)\end{array}$ & $\begin{array}{c}\text { Precipitação } \\
\left(10^{6} \mathrm{~m}^{3} / \mathrm{a}\right)\end{array}$ & $\begin{array}{c}\text { Escoamento total } \\
\left(10^{6} \mathrm{~m}^{3} / \mathrm{a}\right)\end{array}$ & $\begin{array}{c}\text { Escoamento básico } \\
\left(10^{6} \mathrm{~m}^{3} / \mathrm{a}\right)\end{array}$ \\
\hline Mogi-Guaçu & 9820 & 12972,1 & 3342,9 & 2267,4 \\
Pardo & 8088 & 11075,4 & 2928,8 & 2046,2 \\
\hline
\end{tabular}

\subsubsection{Subsuperficiais}

As três formações geológicas encontradas na região Botucatu, Pirambóia e Serra Geral, constituem aqüíferos de água subterrânea. Porém, o aqüífero mais importante da região fornecendo cerca de $70 \%$ de água subterrânea da área, é o arenito da formação Botucatu.

Segundo DAEE (1975), a camada arenosa saturada de água mergulha na direção oeste, subjacente aos basaltos e estende-se além dos limites do Estado de São Paulo. Estes sedimentos assentaram-se sobre a formação Pirambóia, cuja parte superior é composta principalmente por areia com presença de finos e de lâminas argilosas. A espessura do Botucatu é estimada entre $60 \mathrm{~m}$ a leste e mais de $100 \mathrm{~m}$ a oeste, com o possível acréscimo de até $200 \mathrm{~m}$ superiores do Pirambóia. Ambas as formações aparecem bastante ligadas hidrogeologicamente e portanto são tratadas como um aqüífero único.

De segunda importância, do ponto de vista do potencial de exploração, aparecem os aqüíferos dos basaltos Serra Geral. A espessura deste cresce das bordas para a parte central da Bacia do Paraná, onde ultrapassa $600 \mathrm{~m}$, mas os lençóis de água se encontram nas partes superiores, entre derrames e em lentes de areia intertrapeanas (DAEE, 1975). 
Os solos com boa capacidade de infiltração, os quais possibilitam uma recarga considerável, principalmente para os sedimentos do Botucatu e do Pirambóia, apresentam permeabilidade de cerca de $325 \mathrm{~mm} / \mathrm{a}$ (DAEE, 1975). Os solos sobrejacentes ao basalto apresentam uma boa capacidade de infiltração.

\subsection{Aqüífero Botucatu}

O valor médio da permeabilidade do arenito é da ordem de $3,5 \mathrm{~m} / \mathrm{dia}$. Os valores de transmissividade enquadram-se entre 200 e $540 \mathrm{~m}^{2} /$ dia sendo que nos locais onde se junta

ao arenito Pirambóia, a transmissividade aumenta proporcionalmente. O coeficiente de armazenamento do aqǘífero freático (coincide com a porosidade efetiva), é de $25 \%$, enquanto no caso de confinamento obtém-se valores do coeficiente de armazenamento entre $10^{-3}$ e $10^{-5}$, conforme o grau de confinamento. A capacidade específica média é cerca de $4,5 \mathrm{~m}^{3} /$ hora por um metro de rebaixamento (DAEE, 1975).

\subsection{Aquiúfero Pirambóia}

Nas fácies arenosas da formação, o valor de permeabilidade estimado está entre 2 e $3 \mathrm{~m} / \mathrm{dia}$, com valores inferiores nas fácies siltosas. A transmissividade do Pirambóia depende da espessura das camadas arenosas, das finas lâminas de siltes e argilas, situadas especialmente na parte inferior da formação. A transmissividade estimada pelo DAEE é de $300 \mathrm{~m}^{2} /$ dia. O valor de armazenamento, varia de 15 a $20 \%$ no caso freático e da ordem de $10^{-3}$ a $10^{-5}$ no caso confinado.

\subsection{Aquiúfero Serra Geral}

Os derrames basálticos da Formação Serra Geral apresentam características muito heterogêneas uma vez que o fluxo de água efetua-se principalmente através de suas juntas e fraturas. Assim, os parâmetros permeabilidade, transmissividade e coeficiente de armazenamento, indicam somente as condições hidrodinâmicas localizadas. Análises realizadas pelo DAEE indicam uma variação da transmissividade entre 1 a $95 \mathrm{~m}^{2} /$ dia (média cerca de $20 \mathrm{~m}^{2} /$ dia) e baixos valores de coeficiente de armazenamento. Por outro lado, a porosidade efetiva média (condições freáticas), encontram-se entre 1 a $5 \%$ e a vazão específica da ordem de $1-2 \mathrm{~m}^{3} / \mathrm{h} / \mathrm{m}$. 


\subsubsection{Vegetação}

O duto atravessa várias propriedades rurais, dentre as quais se destacam áreas de agricultura intensiva de cítricos e de cana, além de uma extensa área de reflorestamento e cultivo de eucaliptos pertencente à fábrica da Votorantim. A localização e extensão dessas áreas pode ser visualizada no Perfil Geológico - Geotécnico 2 (Anexo 9).

\subsubsection{Meio Antrópico}

No Mapa da Faixa de Influência (Anexo 2) pode-se observar as principais estradas que são cortadas pelo duto e as que estão situadas dentro desta faixa, que são as seguintes:

- SP-330 (Via Anhangüera);

- SP (Via Zequinha de Abreu);

- SP-215;

- SP-328;

- SP-253 (Via Chaffy Jorge);

- SP-253 (Via Conde Matarazzo Jr);

- SP-271;

- SP-328;

- SP-255; 


\subsection{CONSIDERAÇÕES INICIAIS}

Os resultados foram analisados conforme apresentado no fluxograma da Figura26:

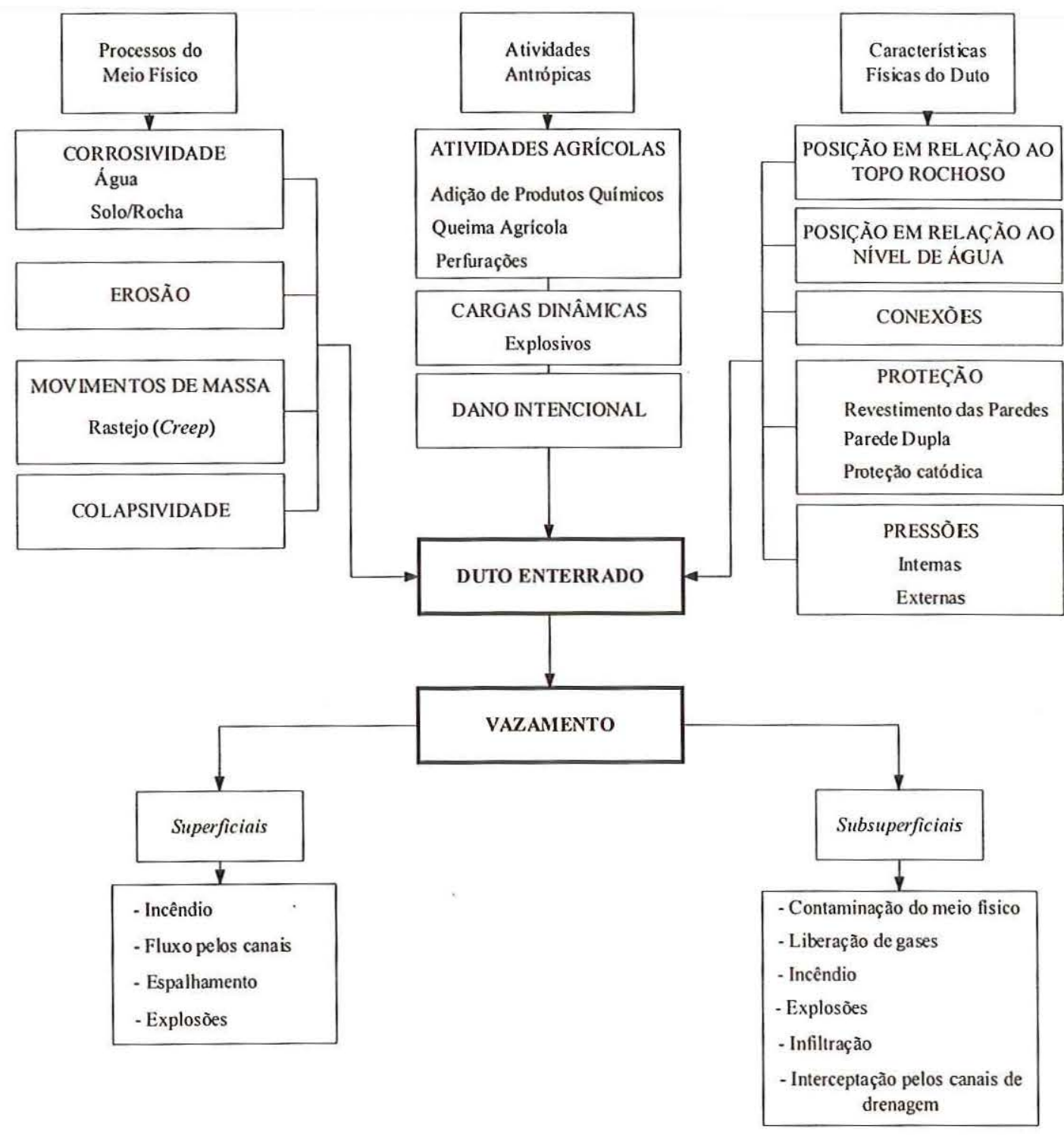

FIGURA 26: Fatores considerados na análise dos resultados. 
Primeiramente foram investigados os aspectos relacionados ao meio físico, às atividades antrópicas e às características físicas do duto, os quais podem gerar condições de instabilização no sistema e de ruptura no duto, provocando vazamentos. Posteriormente foram analisados os problemas ambientais gerados no trecho em conseqüência de um possível vazamento dos produtos transportados em função da condição espacial do vazamento.

\subsection{CONDIÇÕES DE INSTABILIZAÇÃO DO DUTO}

Os fatores que podem gerar condições de instabilização do duto são os seguintes:

- Falhas estruturais (mecânicas);

- Atividades antrópicas;

- Interação entre os componentes do meio físico e o duto.

\subsubsection{Falhas Estruturais}

As falhas estruturais são geralmente causadas por pressões externas ou internas ao duto, por falhas mecânicas geradas por defeitos de fabricação ou de instalação do duto, deficiência no funcionamento das válvulas, por danos intencionais, ou ainda pelo desgaste natural do sistema.

Os locais sujeitos à falha estrutural e mecânica são:

- paredes do duto através do desgaste da pintura de proteção, ou de ineficiência no sistema de proteção catódica, gerando pontos de corrosão;

- conexões através de defeitos de soldagem, nas mantas ou fitas de proteção;

- válvulas de segurança.

As conexões são muitas e estão dispostas ao longo de todo o trecho estudado, em um intervalo de aproximadamente 20 a 20 metros.

As válvulas de segurança estão situadas nas proximidades dos rios mostrados no Mapa da Faixa de Influência (ANEXO 2). Os locais sujeitos a defeitos nas válvulas são:

1) Válvula nas proximidades do Rio Mogi-Guaçu;

2) Válvula situada na área de inundação do Rio Claro; 
3) Válvula na bacia do Rio das Pedras;

4) Válvula lateral ao Rio das Pombas;

5) Válvula lateral ao Ribeirão do Tamanduá;

6) Válvula situada a cerca de 1,9 km do Rio Tamanduá;

7) Válvula lateral à Via Anhangüera, nas proximidades da cidade de Cravinhos;

8) Válvula à cerca de $1 \mathrm{Km}$ da Base de distribuição de Ribeirão Preto.

\subsubsection{Atividades Antrópicas}

As atividades antrópicas que podem gerar defeitos no duto são:

- Adição de produtos químicos;

- Perfurações;

- Utilização de explosivos;

- Dano intencional.

A adição de insumos agrícolas pode modificar o $\mathrm{pH}$ do meio físico, tornando-o ácido e favorecendo o desenvolvimento de processos corrosivos.

As perfurações no solo, geralmente causadas pelo tratamento da terra para plantio, podem danificar o duto através de furos ou ranhuras superficiais, favorecendo o aparecimento de pontos de corrosão.

O dano intencional pode ocorrer preferencialmente nos locais onde o duto está exposto, ou seja nas válvulas (Mapa da Faixa de Influência do Duto - ANEXO 2), paredes do duto e nas bombas de movimentação dos produtos situadas em superfície e, por vezes, bastante desprotegidas.

A utilização de explosivos nas imediações do duto é outro fator que pode instabilizá-lo, levando-o à ruptura.

\subsubsection{Interações entre Meio Físico e Duto}

Os componentes e eventos que podem gerar condições de ruptura ou instabilização do duto, foram determinados através dos atributos analisados na Tabela 10 (Capítulo 3), e na Carta de Zoneamento Geológico - Geotécnico (ANEXO 10).

A área de ocorrência e predisposição a essas interações estão indicadas no Perfil Geológico-Geotécnico 2 (ANEXO 9). 


\subsubsection{Corrosividade}

Os componentes do meio físico que provocam o desenvolvimento da corrosão são o solo, a rocha e a água, os quais podem agir em conjunto ou individualmente. Os materiais ricos em sulfatos de magnésio e de sódio, em sulfetos de ferro e em sais podem reagir com os metais provocando corrosão.

Segundo ZUQUETTE (1987), a profundidade e as variações do nível de água pode expor os tubos em contato com a zona de aeração facilitando a oxidação e a corrosão dos metais. Águas com pH $<7$ e concentração de sais acima de $1000 \mathrm{mg} / \mathrm{l}$, favorecem a corrosão.

As áreas favoráveis ao surgimento de corrosão são mostradas no Perfil GeológicoGeotécnico 2 (ANEXO 9) com o índice "1". Neste documento estão indicados os locais onde o duto está em contato permanente com o nível de água, estando portanto mais suscetível à corrosão. Na Carta de Zoneamentto Geológico-Geotécnico (ANEXO 10), as zonas mais suscetíveis a ação da corrosão são aquelas são aquelas onde o nível de água encontra-se entre zero a 2 metros: A111, A121, A141, A151, B221, B231, B251, B351, C111, C121, C151, C211, C221, C421, C451, D111, D121, E121, E221, E311, E321, F411, F421.

A Figura 27 mostra a válvula de segurança situada na área de inundação do Rio Claro e a Figura 28 mostra o estado avançado de corrosão no qual o duto se encontra, lembrando que suas atividades foram iniciadas em 1996.

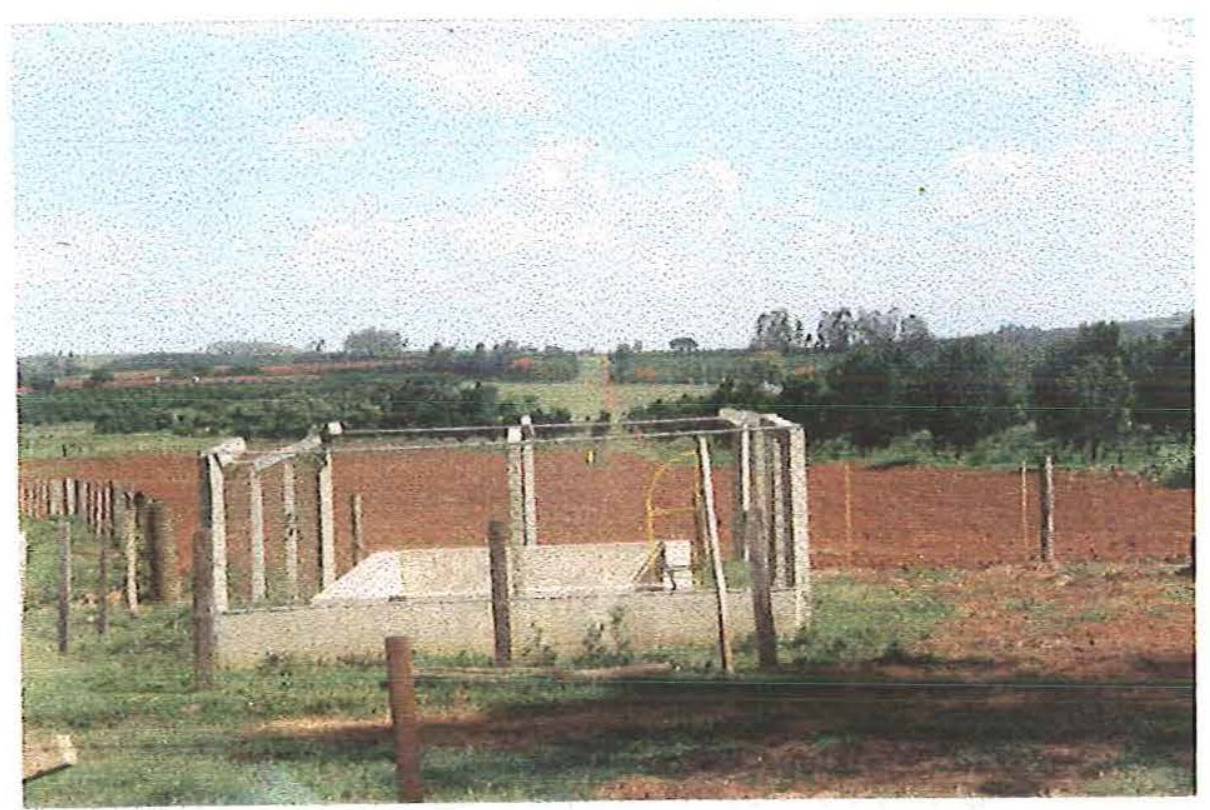

FIGURA 27: Válvula situada na planície de inundação do Rio Claro. 


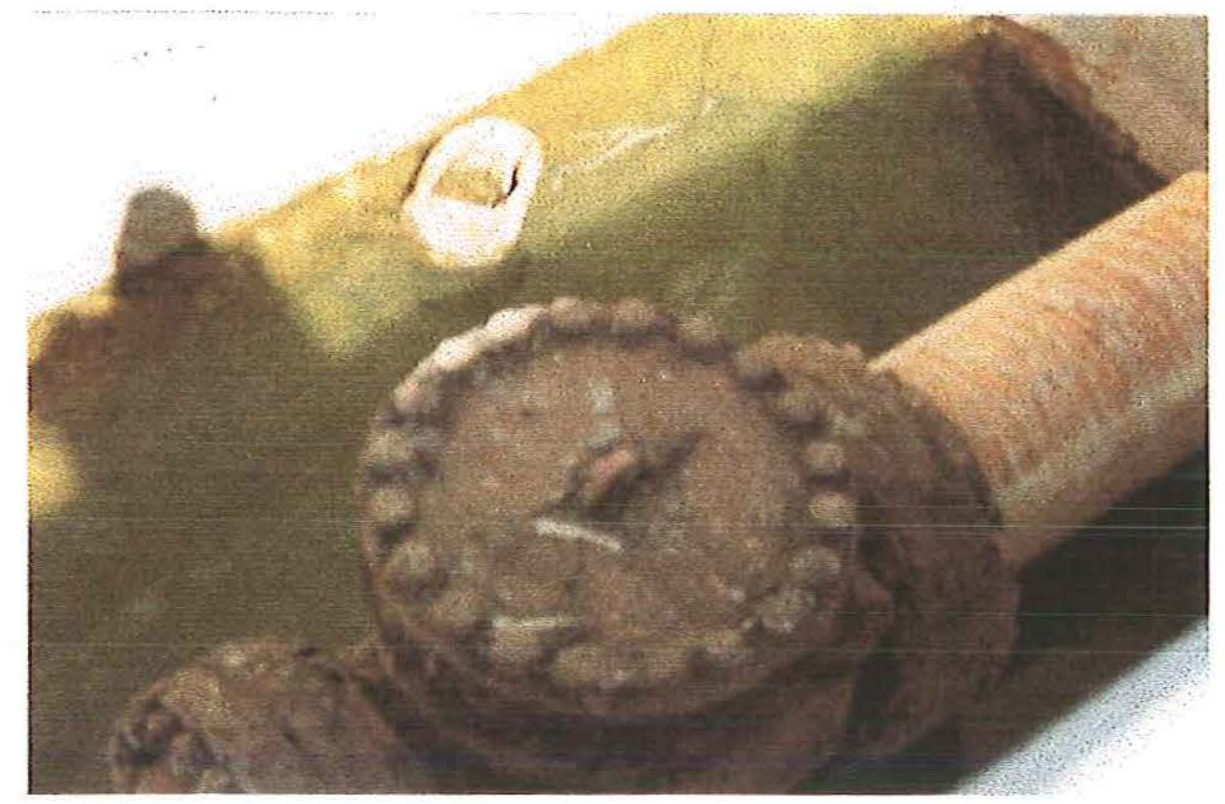

FIGURA 28: Detalhe da válvula.

\subsubsection{Expansibilidade}

A expansibilidade pode ocorrer em locais onde o duto encontra-se próximo ou em contato com materiais contendo minerais argilosos dos tipos 2:1:1, 2:1, ou 1:1 sanfonados e de camadas expansivas abaixo do nível inferior (base) do duto. Tais materiais podem sofrer aumento de volume quando em contato com a água e provocar desvio nos tubos ou pressões excessivas nas paredes dos dutos, rompendo-o.

Este evento pode ocorrer nos locais onde o duto está instalado sobre os argilitos da Formação Corumbataí, e em contato temporário com o nível de água., correspondendo as zonas C421, C422, F411, F421 e F414, na Carta de Zoneamento Geológico - Geotécnico (ANEXO 10), e as áreas indicadas com o número "6" no Perfil Geológico Geotécnico 2 (ANEXO 9). O potencial deste evento ocorrer não é elevado, pois os materiais da Formação Corumbataí não ficarão expostos.

\subsubsection{Rastejo (Creep)}

São movimentos lentos e contínuos de materiais situados em encostas íngremes e sobrepostos à camadas de materiais inconsolidados e/ou rochosos impermeáveis e que 
apresentam o plano de descontinuidade mergulhando na mesma direção da encosta. O pacote constituído por solos, rochas ou blocos, movimenta-se com velocidades muito lentas (mm/ano) devido a ação da gravidade e auxiliado pela infiltração das águas pluviais ou modificações geométricas na região.

A região de ocorrência desse evento na área estudada é geralmente formada por materiais inconsolidados residuais e mistos, situados sobre os basaltos da Formação Serra Geral (Figura 29).

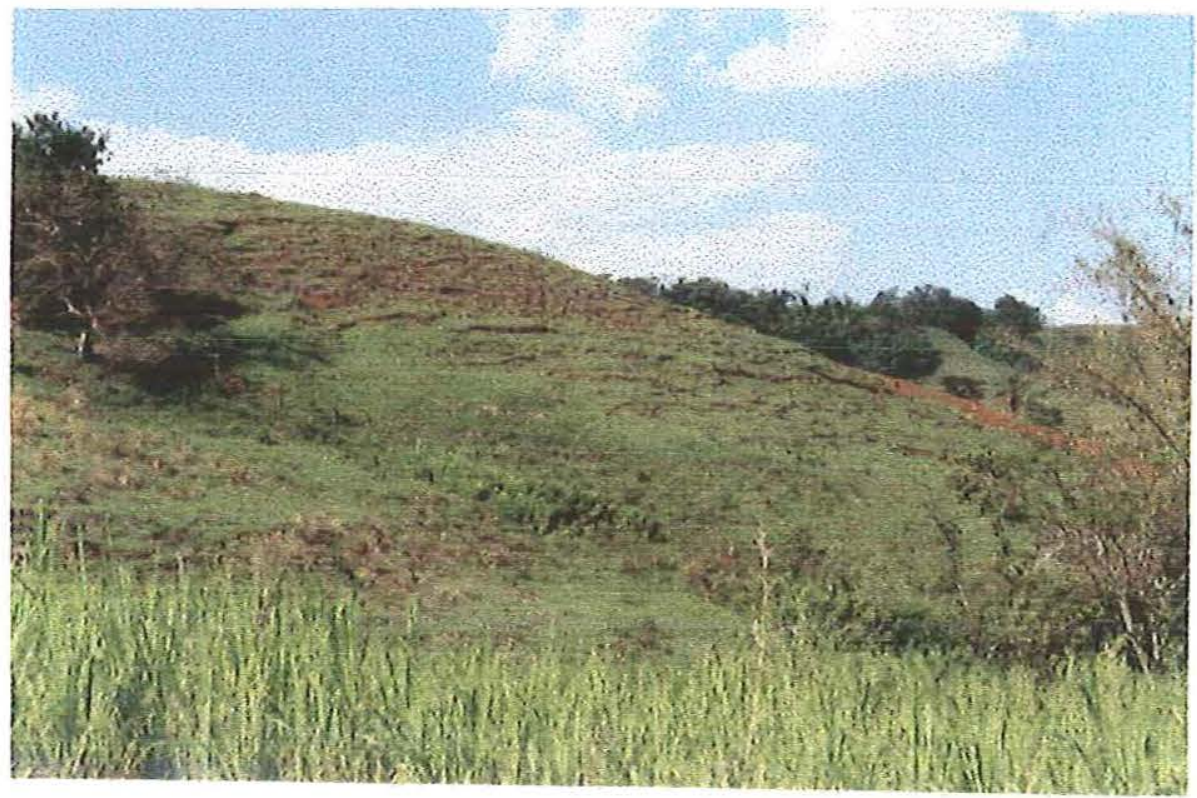

FIGURA 29: Detalhe do processo de rastejo.

As áreas suscetíveis ao rastejo estão representadas com o índice "2" no Perfil Geológico - Geotécnico (ANEXO 9), e na Carta de Zoneamento Geológico-Geotécnico (ANEXO 10) correspondem às zonas A115, A122, A125, A142, A143, A145, A152, A155, C115, C122, C125, C142, C145, C154, D115, D122, D125, D142, D143, D145, D152, D155.

\subsubsection{Colapsividade}

Colapso de solos é um fenômeno caracterizado pela brusca redução de volume do solo, devido ao ganho de umidade, com presença ou não de sobrecarga (COLLARES, 1997). 
O terreno constituído por solos com elevado índice de vazios, o que determina uma estrutura macroporosa, e um teor de umidade menor que o necessário para a sua completa saturação são sujeitos a colapsividade. Esses materiais podem movimentar-se bruscamente devido ao variação volumétrica do solo quando saturado, como resultado do colapso de sua estrutura. Essa movimentação pode promover a ruptura do duto quando atingir maiores intensidades.

Existem diversos critérios que podem ser utilizados para avaliar a colapsividade de um solo. A Tabela 20 apresenta alguns desses critérios:

TABELA 20: Critérios de identificação de solos colapsíveis utilizando-se $\rho_{d}$ e $s_{r}$. (Modificado de NEVES, 1987)

\begin{tabular}{|l|c|c|}
\hline \multicolumn{1}{|c|}{ Critérios } & Solo Colapsível & Solo Não Colapsível \\
\hline Clevenger (1956) & $\rho_{\mathrm{d}} \leq 1,28 \mathrm{~g} / \mathrm{cm}^{3}$ & $\rho_{\mathrm{d}} / 1,44 \mathrm{~g} / \mathrm{cm}^{3}$ \\
Holtz \& Hilf (1961) & \\
\hline Markin (1969) & $\mathrm{s}_{\mathrm{r}}<60 \%$ & $\mathrm{~s}_{\mathrm{r}}>60 \%$ \\
Dudley (1970) & $13 \%<\mathrm{s}_{\mathrm{r}}<39 \%$ & \\
Knodel (1981) & $\mathrm{s}_{\mathrm{r}}<70 \%$ & $\mathrm{~s}_{\mathrm{r}}>70 \%$ \\
& & \\
\hline Mello (1973) & $\mathrm{Gc}<80 \%$ & $\mathrm{Gc}>80 \%$ \\
\hline
\end{tabular}

$\rho_{\mathrm{d}}$ : massa específica aparente seca.

$\mathrm{s}_{\mathrm{r}}$ : grau de saturação.

Gc: grau de compactação de campo.

Zuquette (1993) obteve, nas amostras de materiais inconsolidados da região, valores de $\rho_{d}$ natural variando entre 1,017 e $1,270 \mathrm{~g} / \mathrm{cm}^{3}$, e que se comparado com os $\rho_{d}$ máximos obtidos pelos ensaios de proctor normal da ordem de 1,6 a $1,8 \mathrm{~g} / \mathrm{cm}^{3}$ originam um grau de compactação de campo $(G c)$ com tendências a serem menores que $80 \%$, indicando potencial para colapsividade.

Adotando-se um conjunto de atributos que são os índices dos diferentes critérios pode-se avaliar que as áreas sujeitas a colapsividade são constituídas por materiais inconsolidados arenosos ou argilosos, porosos, com índice de vazios elevado $(>1)$, valores de SPT menores que 5, minerais como caulinita, gibsita e outros óxidos e hidróxidos de ferro e alumínio, e índice de plasticidade baixo. Essas áreas estão representadas com o número "3" 
no Perfil Geológico - Geotécnico 2 (ANEXO 9), e são representadas pelas unidades A121, A122, A125, A142, A143, A145, A152, A155, B222, B223, В224, B233, B252, B254, B322, B352, B354, C122, C125, C142, C145, C154, C222, C223, C242, C252, C253, C254, C352, C422, C454, D122, D125, D142, D143, D145, D152, D155, D252 e D253, na Carta de Zoneamento Geológico-Geotécnica (ANEXO 10).

\subsubsection{Erosão}

O processo erosivo é definido como o resultado decorrente do destacamento e transporte de partículas das rochas e solos por agentes como a água, gelo e o vento.

No Brasil o principal agente erosivo é a água pluvial, por meio das gotas de chuva ou devido ao escoamento superficial. As maiores feições erosivas são produzidas pelo escoamento superficial que normalmente é afetado pelas diversas atividades antrópicas.

Esses processos ocorrem predominantemente em materiais arenosos e arenoargilosos, porosos e pouco coesos.

A predisponência de uma região aos processos erosivos é avaliada considerando a erodibilidade dos materiais (propriedade intrínsica) e a erosividade do agente deflagador (escoamento superficial). A erosividade do escoamento superficial é função da intensidade de energia e portanto da capacidade de destacar e transportar os materiais.

Na região as diferentes atividades antrópicas favorecem a concentração das águas e portanto o aumento da erosividade. No caso de dutos, a característica longitudinal da obra é mais um fator a favorecer a erosividade.

A erodibilidade pode ser avaliada por índices empíricos obtidos em ensaios específicos ou por meio das qualidades (atributos) dos materiais como granulometria, cimento, porcentagem de matéria orgânica, peso específico natural e aparente seco, porcentagem de silte e argila, estruturação, grau de floculação e mineralogia. Na região em questão os materiais inconsolidados residuais ou retrabalhados das Formações Botucatu e Pirambóia reúnem um conjunto de características que permitem classificá-los como de alta erodibilidade.

Na região, os processos erosivos são favorecidos pelas atividades rurais, abertura de estradas vicinais sem sistemas de canalização de água, escavações, ocupação desordenada, retirada da cobertura vegetal e devido à instalação do próprio duto. Essas modificações no meio físico geralmente alteram as condições naturais pré-existentes 
promovendo o aumento do escoamento superficial e consequentemente o arraste dos materiais, tendo como resultado o aparecimento de feições erosivas.

No Perfil Geológico-Geotécnico 2 (ANEXO 9), as áreas sujeitas à este processo são indicadas com o número "4", onde é possível perceber que os mesmos ocorrem em materiais associados à Formação Botucatu e Pirambóia. As unidades B212, B221, B222, B223, B 224, B231, B233, B251, B252, B254, B322, B351, B352, C211, C212, C213, C214, C221, C222, C223, C242, C252, C253, C254, C352, da Carta de Zoneamento GeológicoGeotécnico são as que apresentam maiores predisponências à erosão.

Na Figura 30, observa-se a presença de feição erosiva em estrada secundária, numa região de plantação de cana-de-açúcar nas proximidades de Cravinhos. Esta erosão ocorre em material misto areno-argiloso associado a Formação Botucatu e está relacionado a uma condição de alta erosividade devido ao escoamento superficial favorecido pela entrada concentrada das águas superficiais.

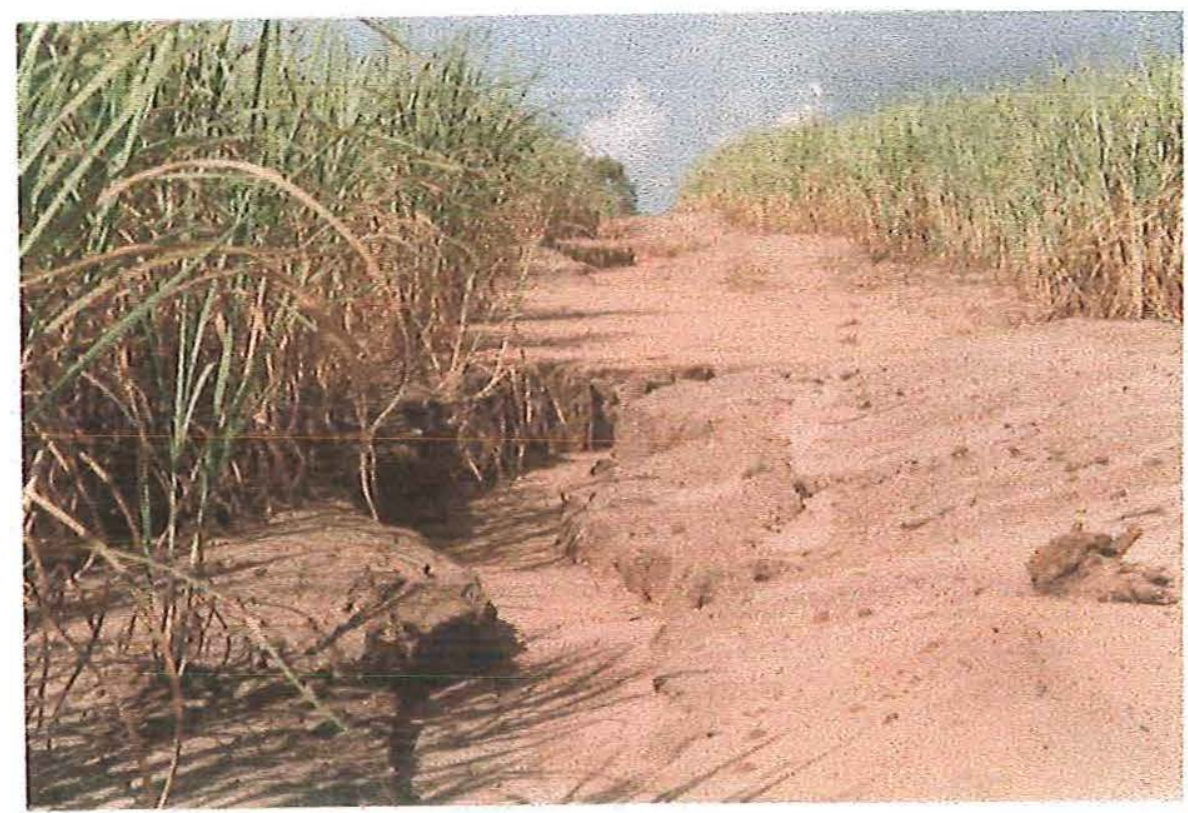

FIGURA 30: Feição erosiva em estrada secundária na região de Cravinhos 
A Figura 31 mostra a faixa de servidão do OSBRA, situada nas propriedades da fábrica Votorantim Celulose, onde foram colocados sacos de areia como sistema de contenção do escoamento superficial para impedir o aparecimento de processos crosivos.

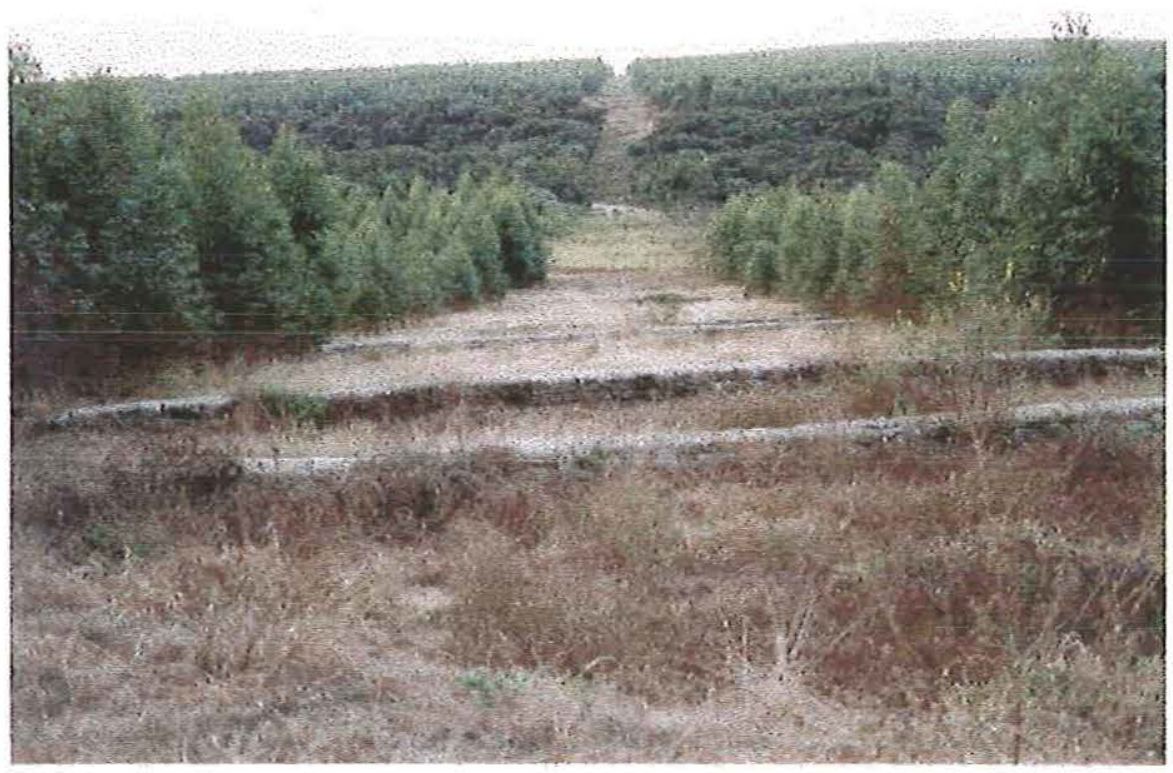

FIGURA 31: Sistema de contenção contra erosão.

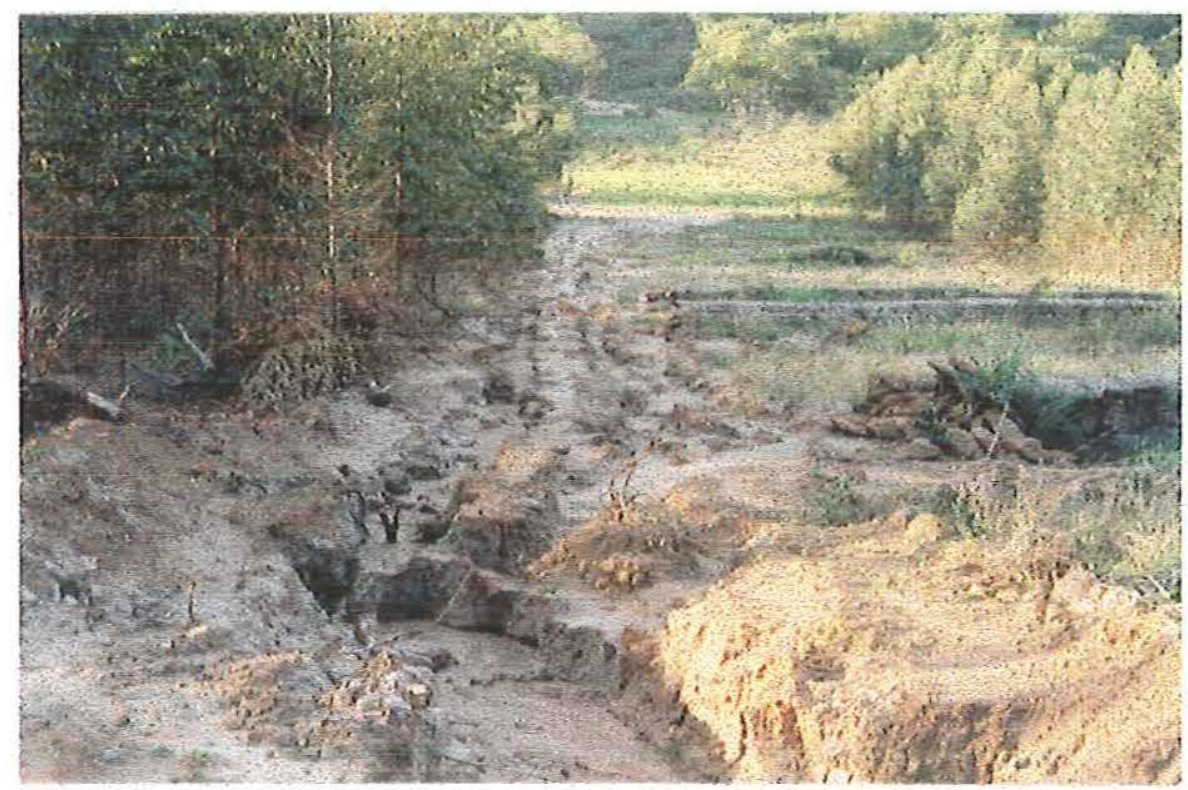

FIGURA 32: Erosão na faixa de servidão. 
A Figura 32 mostra este mesmo local, 5 meses após a instalação, quando a erosão já estava bastante desenvolvida.

\subsection{AVALIAÇÃO DOS PROBLEMAS DE POLUIÇÃO DAS ÁGUAS}

Os problemas ambientais gerados por possíveis vazamentos devem ser analisados com base nos fatores que influenciam o comportamento desses contaminantes no meio ambiente, os quais estão relacionados as características físico-químicas dos produtos transportados e dos componentes do meio físico.

Buscou-se, nesta avaliação, salientar a importância de se conhecer os possíveis mecanismos de contaminação em conseqüência de vazamentos.

Devido a periculosidade desses produtos e aos níveis que atinjam o meio ambiente, os efeitos gerados por vazamento podem ocorrer da seguinte maneira:

1) Explosão e incêndio;

2) Contaminação do solo e da rocha;

3) Contaminação da água subsuperficial e superficial.

Em caso de vazamentos, o produto liberado pode contaminar o meio ambiente por duas maneiras:

1) Infiltração;

2) Escoamento em superfície.

No caso da infiltração, parte do contaminante pode sofrer volatilização, sorção, dissolução e parte permanece como fluido imiscível móvel (fase livre). Enquanto que no caso de um vazamento em superfície, parte do contaminante sofrerá dissolução, volatilização e parte permanecerá como uma fase líquida imiscíveis sobre o nível de água.

\subsubsection{Perigo de Explosão e Incêndio}

O perigo de explosão e incêndio é maior nos período de seca, entre os meses de abril e setembro, pois é nesta época que ocorrem as queimadas agrícolas. Pode ocorrer ainda 
o armazenamento dos gases liberados caso o meio físico apresente características que favoreçam este processo.

\subsection{2. Águas Subsuperficiais}

Os produtos transportados pelo OSBRA - GLP, QAV, diesel, gasolina e álcool são transferidos da refinaria de Paulínia até a base de Ribeirão Preto, sob pressões muito elevadas. Consequentemente, em caso de acidentes esses produtos serão lançados no meio sob pressões também elevadas. $\mathrm{O}$ volume liberado, no entanto, dependerá de vários outros fatores difíceis de prever, tais como diâmetro do(s) furo(s) no caso de pontos de corrosão, dimensão da ruptura no caso de rompimento decorrente da perda de sustentação do solo ou deslocamento entre os tubos.

Outro fator importante a ser considerado é que a maioria desses produtos são imiscíveis, exceto o álcool que é completamente miscível. Desta forma, os produtos imiscíveis formarão uma fase adicional quando em contato com a fase aquosa e a fase miscível será totalmente solubilizada. Todos apresentam perigo de explosão quando em contato com a atmosfera e tendem a sofrer volatilização parcial ou total como no caso do GLP.

O produto liberado tenderá inicialmente a infiltrar verticalmente no meio físico, por ação da gravidade, até atingir o nível de água ou ate ser imobilizado devido a presença de materiais menos porosos, ou não superar os valores da saturação residual no trecho não saturado.

A migração desses produtos depende de suas propriedades físico-químicas e das características dos materiais geológicos presentes na área, os quais podem favorecer ou dificultar a migração dos contaminantes até que esses possam atingir o nível de água. Quanto ao substrato rochosos existem duas situações:

(1) Rochas que funcionam como barreira, impedindo a infiltração dos contaminantes. São aquelas que apresentam condutividades hidráulicas baixas, como os argilitos da Formação Corumbataí; 
(2) Rochas permeáveis ou fraturadas que favorecem a percolação e a infiltração dos contaminantes, representadas pelas formações Pirambóia, Botucatu e Serra Geral fraturada.

Quanto aos materiais inconsolidados pode-se dizer que todos possuem características geotécnicas muito semelhantes, apesar de terem evoluções diferentes. Os materiais argilosos, por exemplo, sejam mistos ou residuais possuem condutividades hidráulicas e porosidades elevadas e, igualmente aos arenosos, favorecem a infiltração dos contaminantes.

Dentre os principais fatores do meio físico que influenciam a migração destacamse a porosidade, a profundidade da zona saturada, as forças de capilaridade, a presença de água nos poros, e o conteúdo de carbono orgânico dos sólidos. Parte do contaminante orgânico pode ser sorbida caso os minerais que compõem o solo contenham mais de $0,1 \%$ de carbono orgânico. O duto, no entanto, está localizado a uma profundidade de 1,5 metros, longe da área de atuação da matéria orgânica, pois freqüentemente esta ocupa a parte mais superficial do solo, em torno de 0,5 metros de profundidade, salvo nos aluviões onde pode alcançar maiores profundidades.

A presença de água nos poros impede a passagem dos contaminantes gasolina, QAV e diesel pois estes são imiscíveis, somado a isso forças de capilaridade tendem a impor resistência à passagem do contaminante à níveis mais profundos. Por outro lado o acúmulo de material vazado faz com que o contaminante supere essas barreiras e infiltre.

Camadas de materiais impermeáveis também funcionam como barreira para o fluxo vertical. O contaminante então pode espalhar-se sobre o plano da barreira até atingir locais com permeabilidade maior ou até interceptar canais de drenagem.

Os principais fatores que afetam a zona atingida pelo espalhamento lateral são a taxa e o volume de material liberado e a presença de permeabilidades significativamente contrastantes. O volume de material liberado influencia o espalhamento lateral do contaminante. Por exemplo, um grande volume de material liberado instantaneamente na zona não saturada terá um elevado grau de espalhamento em comparação a um pequeno volume liberado continuamente.

A migração da fase livre sobre o nível de água deixa, após a sua passagem, restos de contaminantes retidos nos poros. A permanência da fase sorbida do produto no solo funciona como uma fonte contínua de contaminantes para a água subsuperficial. 
Outro aspecto considerado é que nos locais onde o duto está situado sob o nível de água, o produto vazado flutuará sobre o mesmo, o que ocorre tanto nos canais de drenagem quanto nos materiais inconsolidados.

\subsection{3. Águas Superficiais}

Caso ocorram acidentes nos vales próximos aos rios, o produto liberado tenderá a infiltrar o meio poroso até atingir o nível de água ou um material impermeável que funcione como barreira. O contaminante pode ainda migrar lateralmente segundo o fluxo de água subsuperficial ou sobre o material de baixa permeabilidade até ser interceptado pelos canais de drenagem, quando fluirá sobre as águas dos rios.

Da mesma forma, se o acidente ocorrer em canal de drenagem os contaminantes fluirão sobre as águas como uma fase imiscível, no caso do diesel, QAV e da gasolina, e miscível no caso do álcool.

\subsubsection{Perfis Esquemáticos}

No sentido de avaliar o comportamento dos contaminantes em termos de percolação e de contaminação da zona saturada e não saturada, é que foram selecionados 5 perfis básicos que estão esquematizados com o objetivo de demonstrar os diferentes contextos de ocorrência do processo ao longo do trecho, de acordo com o tipo e espessura do material inconsolidado, do tipo e espessura do substrato rochoso, e da profundidade do nível de água.

Antes de analisar cada perfil deve-se considerar que o comportamento do contaminante quanto à infiltração e o seu destino depende do volume de produto liberado. Porém , considerando satisfeita esta condição pode-se passar a discussão dos perfis a seguir, os quais estão relacionados ao Perfil Geológico-Geotécnico 2 (ANEXO 9).

\subsubsection{Perfil 1}

O perfil ilustra a situação de materiais residuais argilosos, com aproximadamente 2 metros de espessura, condutividade de $10^{-2}$ a $10^{-4} \mathrm{~cm} / \mathrm{s}$ e $50 \%$ de porosidade, índice de vazios igual a 1, recobrindo os basaltos da Formação Serra Geral. Sabe que esta formação encontrase fraturada e que suas fraturas muitas vezes constituem bons aquíferos, portanto sujeitos à contaminação. O duto, situado a 1,5 metros de profundidade, representa um perigo eminente

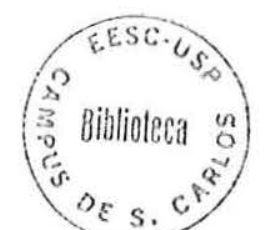


de contaminação desses aqüíferos situados à apenas 0,5 metros de distância do duto. Este perfil é típico da zona A115 da Carta de Zoneamento Geológico-Geotécnico (ANEXO 10).

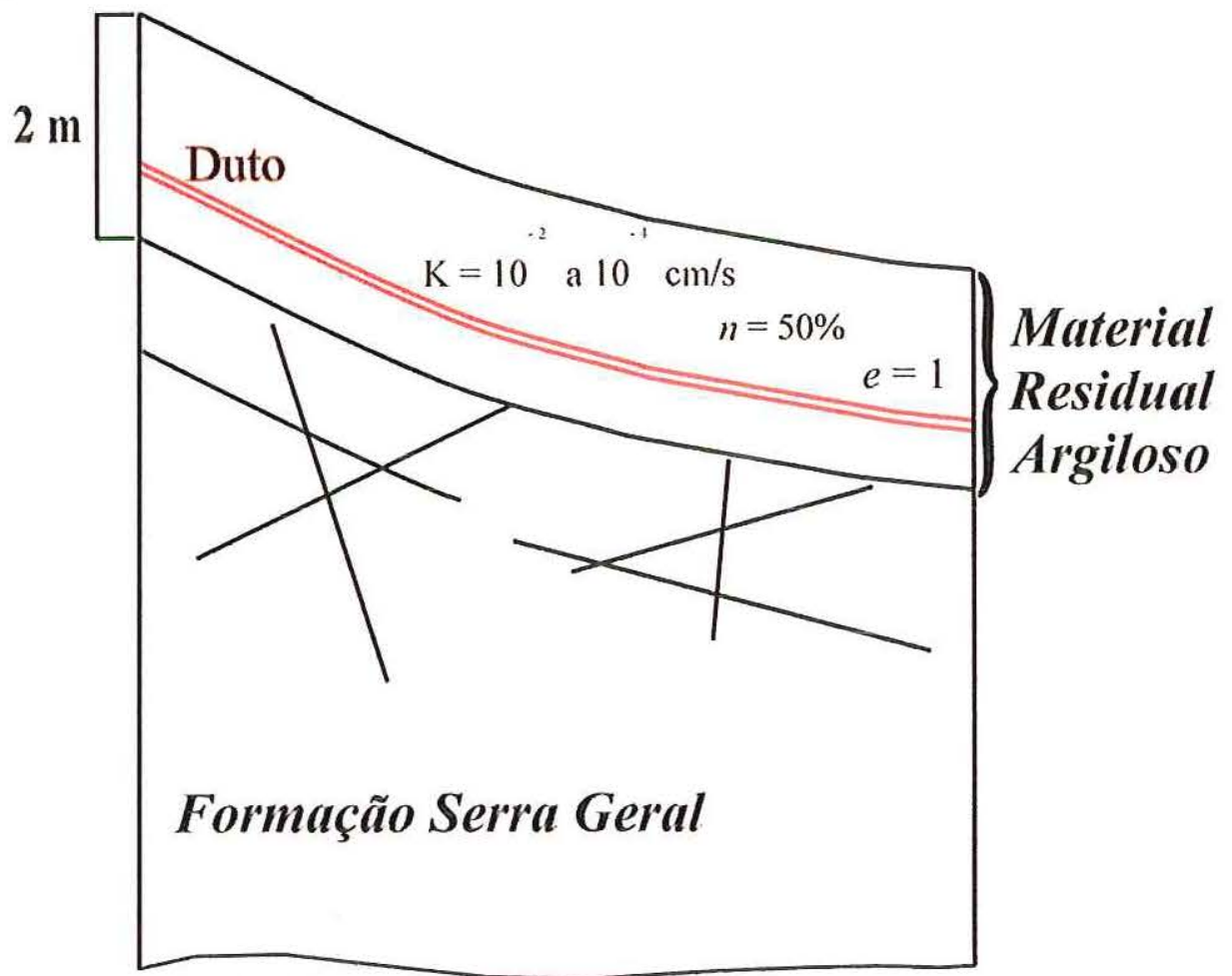

FIGURA 31: Perfil esquemático 1.

Caso o produto liberado seja o GLP este tenderá inicialmente a ocupar as porções inferiores do material inconsolidado próximas ao duto, na forma líquiida, devido às elevadas pressões com que é transportado. Sob efeito dessa pressão o GLP poderá atingir e ocupar completamente as fraturas não preenchidas por água. Caso essas fraturas apresentem condições de trapeamento, os gases liberados podem ficar retidos nesses locais apresentando perigo de auto-ignição em conseqüiência da expansão desses gases.

Por se tratar de uma mistura de compostos gasosos, isto é butano e propano, o GLP tende a sofrer rápida volatilização quando em contato com a pressão atmosférica. Devido a essa diferença de pressões os componentes do GLP podem gerar explosões e incêndio.

No caso do produto derramado ser álcool, gasolina, QAV, ou diesel, parte do contaminante sofrerá volatilização e parte infiltrará o solo. A porção volatilizada pode ficar retida nos poros do solo ou partir em direção as porções superiores do perfil e serem lançadas no ambiente. A parte líquida infiltrante logo atingirá o substrato rochoso, devido a pequena espessura de solo sob o duto, alojando-se nas fraturas existentes na rocha.

Duas situações podem ocorrer nas fraturas preenchidas por água:

1) Caso o álcool seja o produto vazado, este será totalmente miscível em água, formando uma única fase; 
2) Caso o produto seja QAV, diesel ou gasolina, parte destes produto será solubilizada e parte permanecerá como uma fase separada "imiscível". Com o tempo os componentes presente na fase livre serão dissolvidos na água

A ação de remediação do contaminante, indicada para esta situação, deverá ser realizada através da extração dos vapores presentes no solo e, se possível, do bombeamento da fase livre e dissolvida presente nas fraturas. Uma alternativa adicional seria a bioremediação, promovendo assim a degradação dos contaminantes presentes no solo e na água subsuperficial. Um aspecto importante a ser considerado é que a extração do contaminante em meio fraturado é extremamente difícil, e a sua eficiência depende fundamentalmente do conhecimento real da distribuição das fraturas.

\subsubsection{Perfil 2}

Este perfil é constituído por material residual argiloso, com 4 metros de espessura, recobrindo os basaltos da Formação Serra Geral, sobre os arenitos da Formação Botucatu. O duto, situado a 1,5 metros de profundidade, encontra-se a 2,5 metros de distância do substrato rochoso.

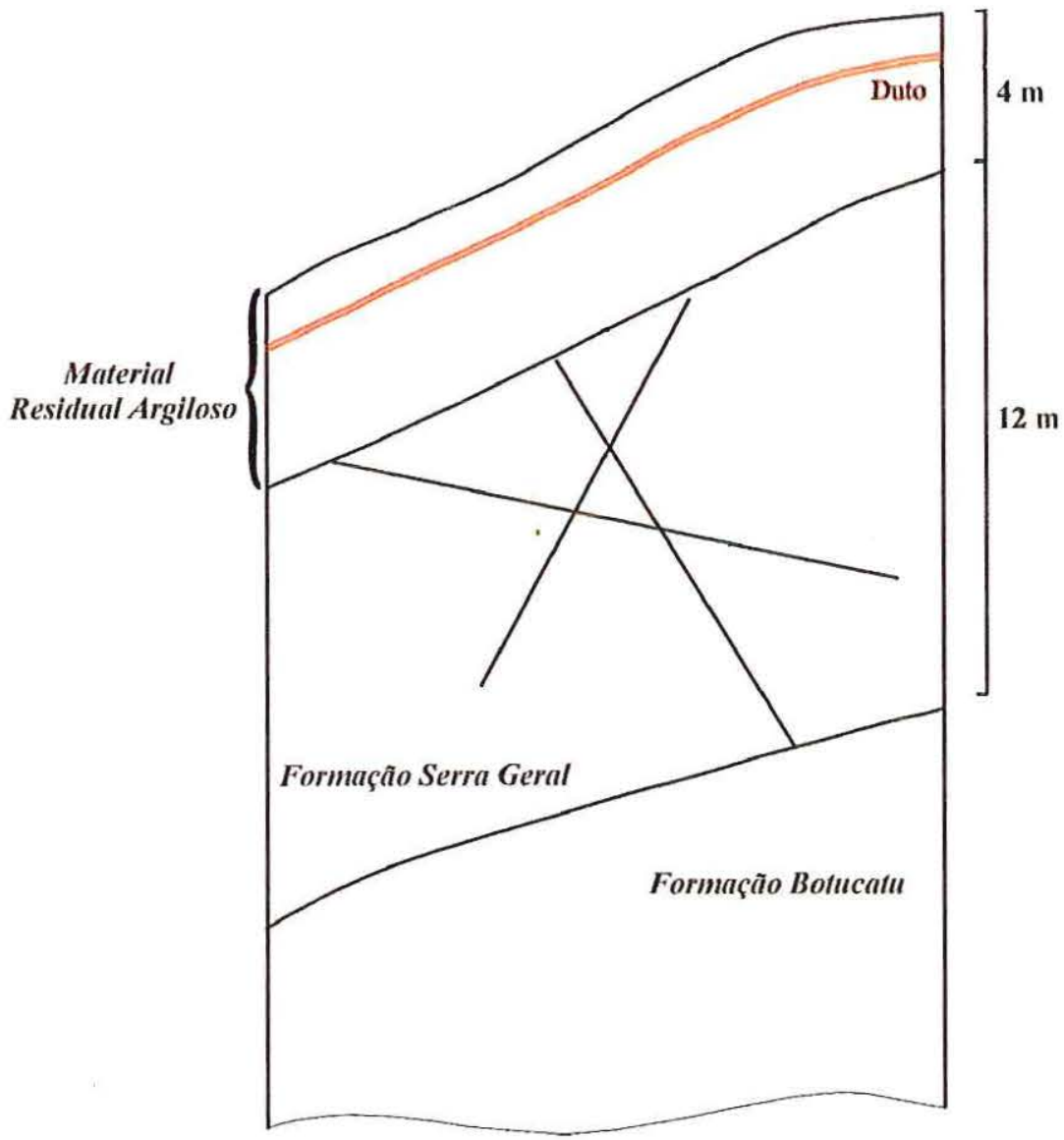

FIGURA 32: Perfil esquemático 2. 
As características de migração do contaminante, caso este seja constituído por GLP, são muito similares a do perfil 1, exceto pela maior distância existente entre o duto e o substrato, o que pode difícultar a migração do GLP para níveis mais profundos do perfil. Assim, os gases migrarão para as porções superiores do perfil, devido a diferença de pressão, podendo ficar retidos nos poros do solo ou partir para a atmosfera.

Caso o contaminante seja álcool, gasolina, QAV ou diesel, uma parte do contaminante será rapidamente volatilizada, migrando para as porções superiores do perfil, enquanto outra parte infiltrará o solo podendo atingir o substrato rochoso. As fraturas presentes no basalto funcionam como um caminho preferencial de fluxo para esses contaminantes. Devido a espessura de 12 metros de basaltos as fraturas devem apresentar condutos contínuos entre o material inconsolidado e o Botucatu. Caso estas fraturas estejam conectadas entre si ou ligadas aos arenitos da Formação Botucatu, estes produtos poderão atingir a zona saturada no Botucatu. Se o produto derramado for o álcool, ele será totalmente solubilizado enquanto o QAV, a gasolina e o diesel permanecerão como uma fase líquiida separada sobre o nível de água, fluindo na mesma direção do fluxo de água subsuperficial. Os componentes da fase livre serão solubilizados com o tempo e através do contato entre os mesmos e a água.

A remediação do local é bastante difícil em função das características físicas representadas no perfil, isto é o substrato rochoso espesso e fraturado praticamente impossibilita a remediação através de bombeamento. Os vapores existentes no solo podem ser retirados através do método comumente conhecido como Soil Vapor Extraction (SVE). A remoção do contaminante presente nos arenitos da Formação Botucatu é praticamente impossível devido a presença da camada dos basaltos da Formação Serra Geral. A melhor alternativa seria escolher uma região não recoberta pelos basaltos ou com pequena espessura dessa Unidade, sob a qual passasse o fluxo de água subterrânea contaminada, pois dessa forma o método do bombeamento seria mais efetivo, a um custo menor.

\subsubsection{Perfil 3}

Este perfil representa as áreas constituídas por material residual arenoso, com 5 metros de espessura, condutividade hidráulica variando entre $10^{-2}$ a $10^{-3} \mathrm{~cm} / \mathrm{s}$ e $50 \%$ de porosidade. O nível de água situa-se nos arenitos da Formação Botucatu, entre 10 a 20 metros de profundidade. Tanto o material inconsolidado quanto a rocha facilitam a infiltração do contaminante até que este alcance o nível de água. O produto será totalmente solubilizado em água, caso o produto liberado seja o álcool. $\mathrm{O}$ que não ocorre no caso do 
diesel, QAV e gasolina, os quais migrarão sobre o nível de água, segundo a direção de fluxo da água subsuperficial como uma fase separada, cujos componentes serão dissolvidos com o tempo.

A distância entre o nível de água e o duto pode dificultar a contaminação da água subsuperficial, dependendo do volume de material liberado. Essa distância pode favorecer uma maior taxa de liberação de gases a partir dos produtos vazados e pode impossibilitar a contaminação da água subsuperficial com GLP e para pequenos volumes de líquidos liberados.

A técnica de remediação aplicada neste caso seria a extração de vapores do solo e o bombeamento e tratamento dos contaminantes presentes na fase livre e dissolvida. A bioremediação pode ser aplicada para degradar os contaminantes presentes na zona saturada e não saturada. Se a fonte de contaminação não for rapidamente controlada, um aumento do volume de contaminante infiltrará atingindo níveis mais profundos e dificultando a recuperação do produto liberado.

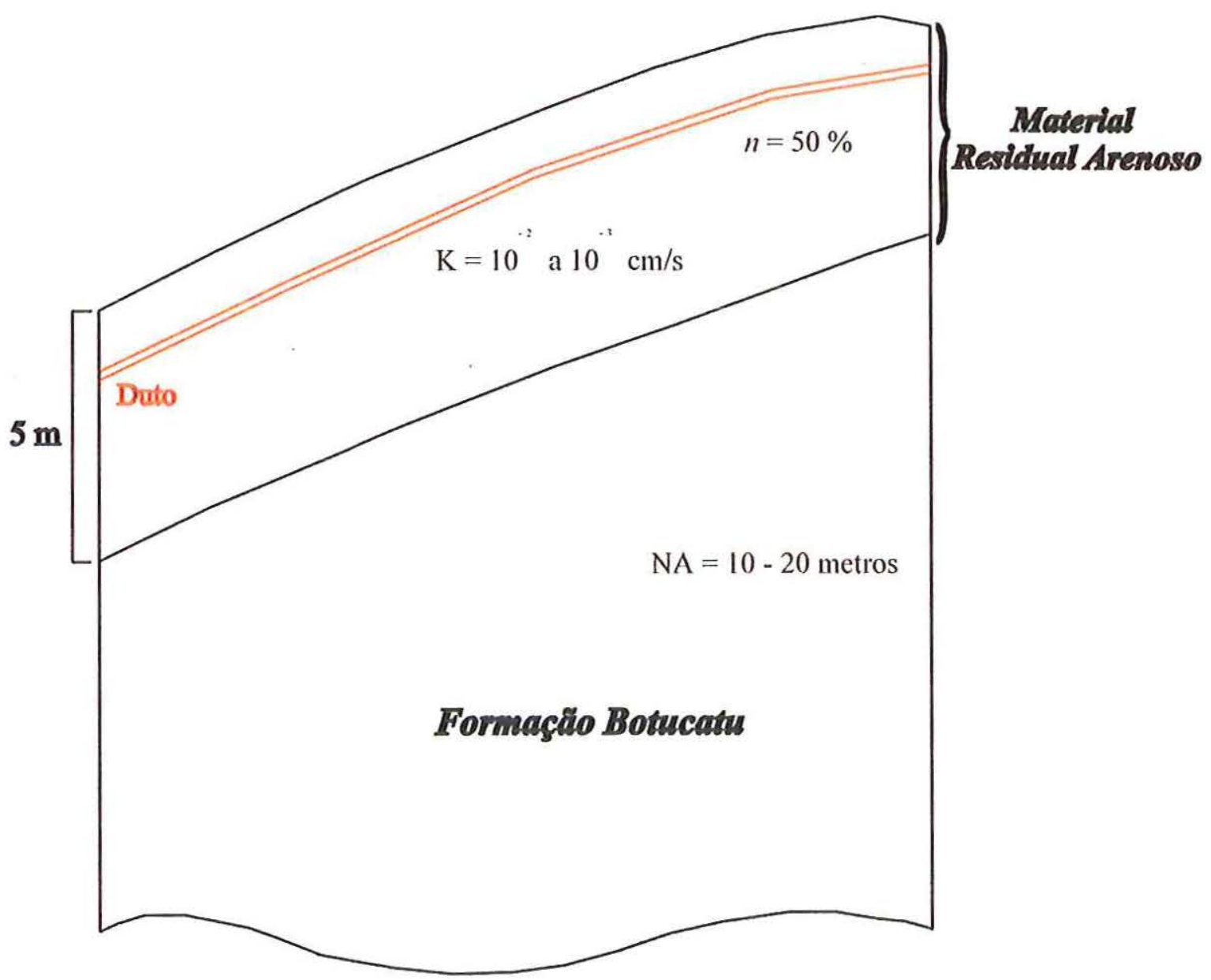

FIGURA 33: Perfil esquemático 3. 


\subsubsection{Perfil 4}

O perfil é constituído por material residual arenoso, com 10 metros de espessura, condutividade hidráulica de $10^{-2}$ a $10^{-3} \mathrm{~cm} / \mathrm{s}$ e $50 \%$ de porosidade. Neste caso o nível de água encontra-se entre 2 a 5 metros profundidade, ou seja, muito próximo do duto. Isto significa que o contaminante infiltrará pelo perfil por gravidade atingindo o nível de água ainda no material inconsolidado, movendo-se juntamente com o fluxo de água subsuperficial.

Como já foi dito anteriormente, o GLP será lançado no meio físico sob pressões elevadas podendo atingir rapidamente o nível de água na forma líquida. Da mesma forma como ocorre com os gases liberados pelo álcool, gasolina, diesel e QAV, os componentes do GLP volatilizarão rapidamente, migrando para as regiões superiores do perfil. Esses gases podem permanecer no perfil, armazenado nos poros do solo ou migrarem para a atmosfera.

As mesmas técnicas de remediação são aplicáveis nestas condições. Neste caso, a remoção do contaminante é facilitada pela pequena espessura do material e pela proximidade do nível de água.

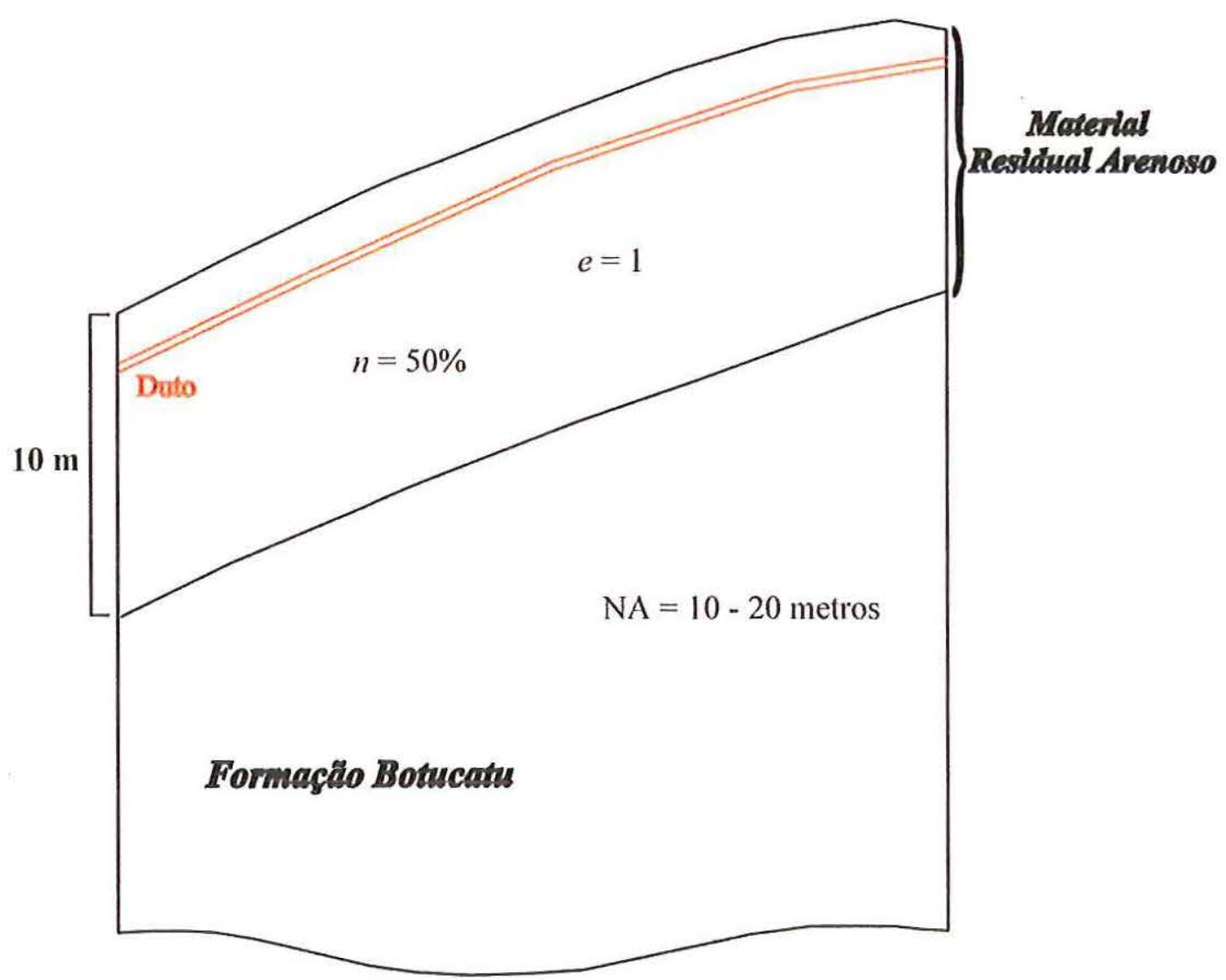

FIGURA 34: Perfil esquemático 4. 


\subsubsection{Perfil 5}

A área mostrada neste perfil é constituída por material inconsolidado misto arenoargiloso com 5 metros de espessura, condutividade hidráulica entre $10^{-2}-10^{-3} \mathrm{~cm} / \mathrm{s}$, índice de vazios $>1$, e nível de água situado entre 2 a 5 metros, recobrindo os argilitos da Formação Corumbataí, cuja condutividade hidráulica é da ordem de $10^{-7} \mathrm{~cm} / \mathrm{s}$.

A proximidade entre o nível de água e o duto facilita a infiltração do produto liberado e a contaminação da água subsuperficial. Quando o QAV, o diesel ou a gasolina atingem o nível de água, os componentes mais solúveis serão rapidamente dissolvidos em água, enquanto os componentes menos solúveis permanecerão em uma fase separada, sendo aos poucos solubilizados.

Sob efeito das elevadas pressões com que o GLP é transportado, este será lançado no meio físico atingindo o nível de água na forma líqüida. No entanto, devido a diferença de pressões, seus componentes tenderão a volatilizar rapidamente migrando para as regiões superiores do perfil.

Caso o vazamento não seja rapidamente detectado e controlado, haverá um acúmulo de material sobre o nível de água, o qual tenderá a migrar para níveis mais profundos do perfil. A presença do substrato rochoso impermeável da Formação Corumbataí, impede o avanço dos contaminantes em profundidade, promovendo o espalhamento lateral. Esse espalhamento ocorrerá em direção à menor declividade, e assim os contaminantes podem ser interceptados pelos canais de drenagem, quando fluirão sobre as águas dos rios. O controle e a extração dos contaminantes presentes nos canais de drenagem são realizados através da utilização de mantas. 


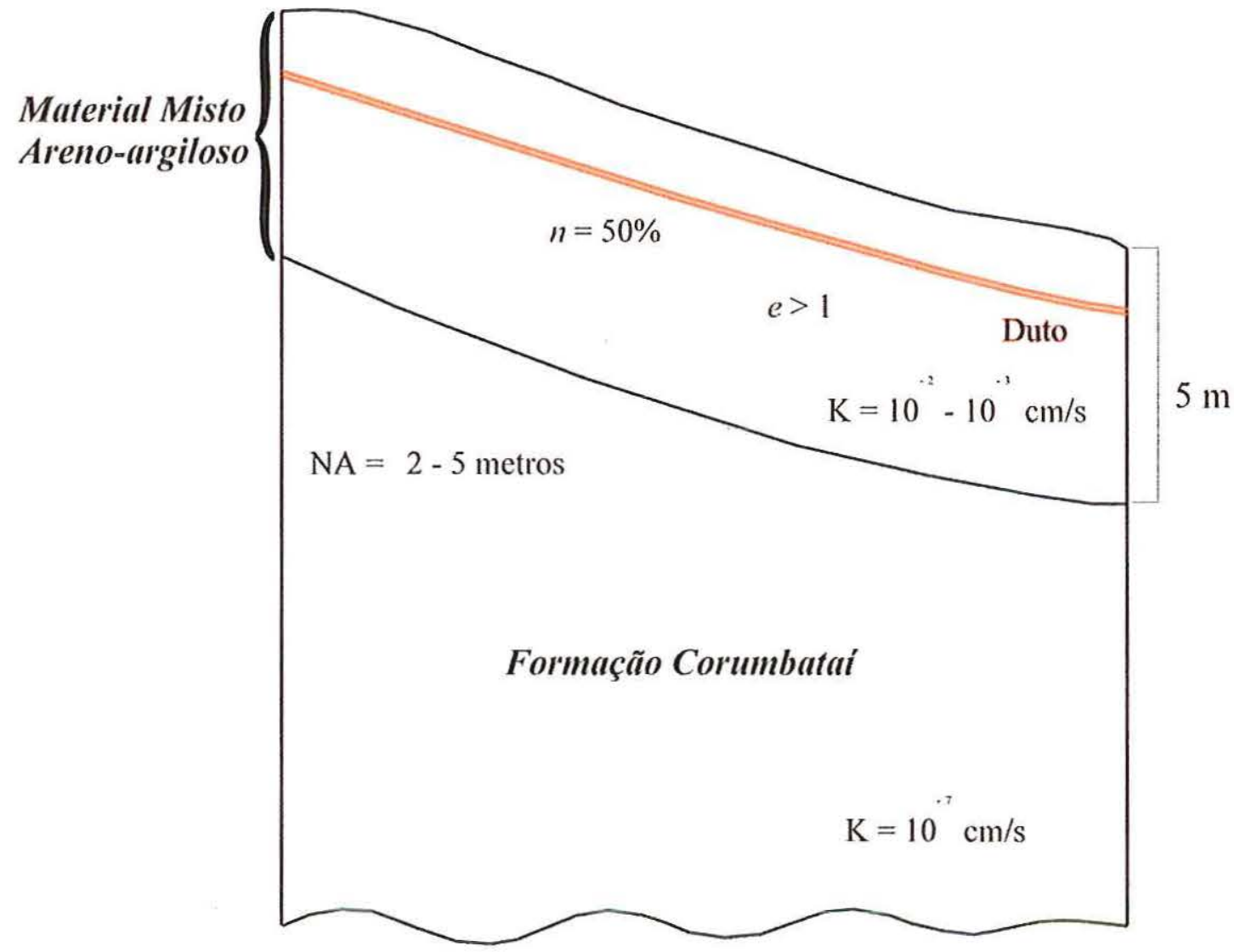

FIGURA 35: Perfil esquemático 5. 
A metodologia adotada neste trabalho mostrou-se satisfatória, visto que permitiu realizar uma análise geral dos problemas relacionados a dutos enterrados e à contaminação gerada pelo vazamento de produtos orgânicos. Este estudo serve portanto como modelo para a realização de outros trabalhos envolvendo a investigação de problemas ambientais relacionados à dutos enterrados.

Considera-se que os objetivos propostos neste trabalho foram alcançados, pois o mesmo permitiu a identificação dos aspectos estruturais e construtivos do duto e dos fatores geológico- geotécicos que podem desencadear acidentes no trecho. Além disso, possibilitou definir os problemas ambientais que podem ocorrer em conseqüência de um vazamento, frente as características do meio físico e dos produtos liberados.

Pode-se observar no Perfil Geológico-Geotécnico 2 (ANEXO 9), a presença de cinco regiões distintas em relação a predisponência à contaminação. Esta potencialidade está, por sua vez, relacionada à possibilidade de ocorrência dos eventos geológico-geotécnicos em cada região e à intensidade que estes eventos podem ocorrer nestas áreas.

A região situada entre os quilômetros 0 e 11 está sujeita a ação da corrosividade, colapsividade, expansibilidade e de produtos químicos. Destes, os principais fatores deflagradores de acidentes são a colapsividade e a corrosão, esta última podendo ser induzida pela ação dos produtos químicos utilizados na agricultura, além do contato permanente ou intermitente entre duto e a zona saturada. A contaminação decorrente de vazamentos nesta região não atingirá níveis mais profundos do perfil devido à presença dos argilitos da Formação 
Corumbataí, considerados impermeáveis. Por outro lado, o material vazado tenderá a ser interceptado pelos canais de drenagem.

Na região situada entre os quilômetros 11 e 22,5 os acidentes podem ser ocasionados por rastejo, colapsividade, erosão e corrosão, podendo esta ser intensificada pela presença de produtos químicos. Destacam-se nesta área os eventos de rastejo, registrados em campo, e de colapsividade.

Entre os quilômetros 22,5 e 59, os prováveis eventos são corrosividade, colapsividade e erosão. Apesar do menor número de eventos deflagradores, se comparados às outras regiões do perfil, destaca-se a importância desta em função do número de zonas associadas à corrosão e da extensão que pode ser atingida. Cabe ressaltar que esta região apresenta atualmente vários registros de erosão, que podem levar à ruptura do duto e consequentemente à contaminação do aqüífero Botucatu.

O trecho situado entre os quilômetros 59 e 81 está sujeito à ação da corrosão, rastejo, colapsividade, erosão e produtos químicos. Dentre os quais, os principais processos são o rastejo e a corrosão. A erosão tende a ocorrer nos materiais inconsolidados que recobrem a Formação Botucatu. Deve-se notar que a ocorrência de vazamentos sobre os basaltos fraturados do trecho entre os quilômetros 59 e 65 representa perigo de contaminação do aqüífero Botucatu.

Os eventos que podem desencadear acidentes no duto, entre os quilômetros 81 e 102, são colapsividade e corrosão através do contato com a zona saturada ou pela presença de produtos químicos.

Sugere-se a instalação de pontos de monitoramento nos locais de ocorrência desses eventos geotécnicos a fim de promover o acompanhamento e o controle dos agentes deflagradores de possíveis acidentes no duto, e assim evitar a ocorrência de vazamentos.

A primeira medida a ser tomada no controle de vazamentos em dutos é o fechamento imediato das válvulas de segurança, para interromper a transferência dos produtos a partir da refinaria e cessar a fonte poluidora. Caso contrário, a contaminação pode atingir volumes e concentrações muito elevadas aumentando o custo da remediação e diminuindo as chances de recuperação do material liberado. Deve-se tentar eliminar o mais rápido possível, os contaminantes presentes nas zonas saturada e não saturada, nas fases livre, dissolvida, vapor e residual., pois todas estas fases representam um perigo de poluição das águas subsuperficiais. No entanto, o que atualmente ocorre é a retirada de parte do material vazado, em função da diferença de solubilidade e de mobilidade dos componentes da mistura, da ausência de 
tecnologia que permita a remoção de todo o contaminante vazado e da dificuldade em determinar o volume de material liberado em um vazamento. Caso seja possível, deve-se remover o produto retido nos poros através da retirada do solo, o que geralmente ocorre por meio de escavações e trincheiras.

As técnicas de remediação mais utilizadas atualmente são o bombeamento e a incineração. Pode-se utilizar bioremediação para obtenção de resultados satisfatórios tanto a curto quanto a longo prazo, dependendo das características do local contaminado.

A modelagem do fluxo e do transporte de contaminantes orgânicos em zona saturada e não saturada esbarra em grandes dificuldades quer pelas características: físico-químicas dos próprios contaminantes ou pela deficiência que a maioria dos programas computacionais apresentam quanto ao número de dados capazes de serem tratados, considerando-se todos os processos físicos, químicos, bioquímicos e de interação com o meio físico, que sabe-se ocorrer na realidade.

No caso de regiões muito extensas, deve-se selecionar áreas menores que representem situações de contaminação específicas, com parâmetros do contaminante e do meio físico bem definidos e previamente determinados, os quais possam ser tratados com sucesso pelo modelo computacional adotado para modelagem numérica. 
AMERICAN PETROLEUM INSTITUTE. (1972). The Migration of Petroleum Products in Soil and Groundwater, Principles and Counter-Measures: Am. Petrol. Inst. p.4149.

BARRETT, M.H.; GIKAS, L.; LERNER, D.N. (1994). The Effects of Cosolutes and Cosolvents on the Adsorption of BTEX Componds from Groundwater. In: Transport and Reactive Processes in Aquifers. Editors: T. H. Dracos \& F. Stauffer. Balkema/Rotterdam. p.125-129.

BOUWER, H. (1978). Groundwater hydrology. McGraw-Hill. Kogakusha, Ltd. (International student edition).

CLEARY, R.M. (1991). Hidrologia Ambiental. Coleção Associação Brasileira de Recursos Hídricos. Edusp. v.3, 414p.

COLLARES, A.C.Z.B. (1997). A influência de características químicas do fluido de saturação no colapso do solo. (Dissertação de Mestrado). USP -Escola de Engenharia de São Carlos.

CONCAWE. (1979). Protection of Groundwater from Oil Pollution. The Hague, Netherlands. Report NTIS PB82-174608.

DAHMANI, M.A., FOSTER, K., AHLFELD, D.P., HOAG, G.E., CARLEY, R.J., CHEN, J. (1993). Measurement of Motor Fuel Contaminated Soil Leachate. In: Hydrocarbon Contaminated Soil and Groundwater. Editors:

Paul T. Kostecki \& Edward J. Calabrese. Chelsea Michigan: Lewis, v.3, p.123-144.

DIETZ, D. N. (1970). Pollution of Permeable Strata by Oil Components. In: 
Water Pollution by Oil. Edited by Hepple, P., New YorK: Elsevier Publishing Co. and Institute of Petroleum, 327p.

DOMENICO, P.A.; SCHWARTZ, F.W. (1990). Physical and Chemical Hydrogeology. New York: Jonh Wiley \& Sons, 824p.

FERREIRA, S.B. (no prelo). Análise do Potencial de Contaminação da Água Subterrânea e Solos por Derramamento de Gasolina Oxigenada. (Tese de Doutorado) USP - EESC.

FERREIRA, S.B.; GRATHWOHL, P.; ZUQUETTE, L.V. (1998). Effect of ethanol on enhancing the solubility of aromatic hydrocarbons contained in oxygenated gasoline. XI Congresso Brasileiro de Mecânica dos Solos e Engenharia Geotécnica. v. 3, p. 17891796, novembro 1998.

FETTER, C.W. (1993). Contaminant Hydrogeology. New York: Macmillan, 458p.

FETTER, C.W. (1994). Applied Hydrogeology, 3.ed.: New York: Macmillan, 691p.

FÚLFARO, V.J.; GAMA JÚNIOR, E.; SOARES, P.C. (1980). Revisão Estratigráfica da Bacia do Paraná. Relatório PAULIPETRO, Consórcio CESP/IPT - 008180, São Paulo.

GILLHAM, R.W \& RAO, P. S. C. (1994) - Transport, Distribution, and Fate of Volatile Organic Compounds in Groundwater p.141-181.

GWINN, P. J.; READ, M. (1997). Cleanup of PCE-Contaminated Groudwater Using an Integrated Pump-and-Treat and Vapor Extraction System. In: In Situ Remediation of the Geoenvironment. p. 312-326. Minneapolis, Minnesota. Oct. 5-8. Published by ASCE (American Society of Civil Engineers).

HASAN, S.E. (1996). Geology and Hazardous Waste Management. New Jersey, Prentice Hall. 387p.

HINCHEE, R.E.; DOWNEY, D.C.; COLEMAN, E.J. (1987). Enhaced bioreclamation, soil venting and ground-water extraction: a cost-effectiveness na feasibility comparison. In: 
Proc. NWWA/API Conf. Petroleum Hydrocarbon Organic Chemistry in Ground Water: Prevention, detection and restoration. Houston, TX. Nov. (1987).

HOVEY, D.J.; FARMER, E.J. (1996). Pipeline Crossing Acidents and Leak Detection Opportunities. Pipeline Crossings. New York: Published by ASCE - American Society of Civil Engineers, p.22-36.

Instituto de Pesquisas Tecnológicas do Estado de São Paulo (1980). Tectônica da Bacia do Paraná no Brasil. Relatório IPT, 14091, São Paulo.

Instituto de Pesquisas Tecnológicas do Estado de São Paulo (1981). Mapa Geológico do Estado de São Paulo: Escala 1:500.000. v. 1 e v. 2.

JOHNSON, P.C.; KEMBLOWSKI, M.W.; COLTHART, J.D. (1990). Quantitative Analysis for the Cleanup of Hydrocarbon-Contaminated Soils by In-Situ Soil Venting. Ground Water no. 3, v. 28, may-june, 1990.

KRUSEMAN, G.P.; RIDDER, N.A. (1970). Analysis and evaluation of pumping test data. Intern. Inst. Land Reclamation and Improvement Bull. Wageningen - The Netherlands.

KUEPER, B.H.; FRIND, E.O. (1988). An overview of immiscible fingering in porous media. Journal of Contaminant Hydrology, v.2, p.95-110,

LEE, M.D.; JAMISON, V.W.; RAYMOND, R.L. (1987). Applicability of in-situ bioreclamation as a remedial action alternative. NWWAI Conference on Petroleum Hydrocarbons and Organic Chemicals in Ground Water - Prevention, Detection, and Restoration. Dublin, Ohio, Proc.: National Water Well Assoc., p.167-185.

LIU, R. (1996). Pipeline Research Needs - Proceedings of the Workshop of Pipelines - Held in Leesburg, Virginia. New York: Published by ASCE - American Society of Civil Engineers.

MERCER, J.W.; COHEN, R.M. (1990). A Review of immiscible fluids in the subsuperface: Properties, models, characterization and remediation: Jounal of Contaminant Hydrology, v.6, p.107-163. 
MIOTO, J.A. (1993). Sismicidade e Zonas Sismogênicas do Brasil. (Tese de Doutorado). UNESP - Câmpus de Rio Claro.

NEVES, M. (1987). Estudo da Permeabilidade do Solo Colapsível da Região de São Carlos. (Dissertação de Mestrado) USP - Escola de Engenharia de São Carlos.

NORRIS, R .D. (1994). Handbook of Bioremediation. New York: Lewis.

OLIVEIRA, E. (1992). Contaminação de Aquiiferos por Hidrocarbonetos Provenientes de Vazamentos em Tanques de Armazenamento Subterrâneo. (Dissertação de Mestrado) USP - Instituto de Geociências SP.

OLIVEIRA, E.; CLEARY, R.W.; CUNHA, R.C.A. (1991). Gasoline Hydrocarbons: Groudwater Pollution Potential in Metropolitan São Paulo. In: Water Science and Technology, no. 11,v.24, p. 189-200.

Office of Technology Assessment (1984). Protecting the Nation's Groundwater from Contamination. Washington, D. C.: U.S. Congress, OTA, v.2. 276p.

PETRI, S.; FÚLFARO, V.J. (1983). Geologia do Brasil. p. 131-132. EDUSP - SP

PETROBRÁS (1996). Informações via fax.

PETROBRÁS (1997). A Companhia - Mapas. Acesso via internet pelo endereço: http://www.petrobras.com.br. (22 mar.)

ROBBINS, E.A.; ROBERTSON, M.; STEUBE, G. (1993). False identification of BTEX compounds using EPA Method 8020. In: Hydrocarbon Contaminated Soils and Groundwater, v.3, p.93-110.

SCHEIDDEGGER, A.E. (1954). Statistical hydrodynamics in porous media. J. Appl. Phys. 25(8), p. $994-1001$. 
SCHROEDER, P.R.; LOYD, C.M.; ZAPPI, P.A. (1994). Users guide for HELP Version 3 for experienced users. EPA/600/R-94/168 a. Washington, DC.: U.S. Environmental Protection Agency. Office of Research and Development.

SCHWARZENBACH, R.P; GSCHWEND, P.M.; DIETER, M.I. (1993). Environmental Organic Chemistry. John Wiley \& Sons, Inc. New York, NY.

SCHWILLE, F. (1988). Dense chlorinated solvents in porous and fractured media: model experiments: Chelsea, Michigan, 688p.

SOARES, P.C. (1975). Divisão estratigráfica do mesozóico no Estado de São Paulo. Revista Brasileira de Geociências, 5 (4): 229-251. São Paulo.

SOARES, P.C.; LANDIM, P.M.B.; FÚLFARO, V.J.; SOBREIRO NETO, A.F. (1980). Ensaios de caracterização estratigráfica do cretáceo no Estado de São Paulo: Grupo Bauru. Rev. Bras. Geoc., 10(3): 177-185. São Paulo.

SOLOMONS, T.W.G. (1996). Química orgânica. Jonh Wiley \& Sons, Inc. v.1.

SPITZ, K; MORENO, J. (1996). A Practical Guide to Groundwater and Solute Transport Modeling. Jonh Wiley \& Sons, Inc. Canadá.

SUTHERSAN, S.S. (1997). Remediation Engineering Design Concepts. Boca Ranton, Florida: Lewis, p.4-13.

TESTA, S.M.; WINEGARDNER, D.L. (1991). Restoration of Petroleum Contaminated Aquifers. Boca Ranton, Florida: Lewis, 269p.

U.S. ENVIRONMENTAL PROTECTION AGENCY, (1989) - Seminar Publication, Transport and Fate of Contaminants in the subsuperface: Report No. EPA/625/019, $148 \mathrm{p}$.

U.S. ENVIRONMENTAL PROTECTION AGENCY, (1991). Groundwater Issue: Report No. EPA/540/4-91/002, 21p. 
U.S. ENVIRONMENTAL PROTECTION AGENCY, (1991). Handbook of Groundwater, Vol. II: Methodology: Report No. EPA/625/6-90/016b, 141p.

VAN DAM, J. (1967). The Migration of Hydrocarbon in a Water Bearing Stratum: Joint Problems of the Oil and Water Industries. Edited by: Hepple. P. London: Institute of Petroleum.

WALTON, W.C. (1970). Groundwater Resource Evaluation. New York: McGraw-Hill. $664 \mathrm{p}$.

YONG, R.N; MOHAMED, A.M.O.; WARKENTIN, B.P. (1992). Principles of Contaminant Transport in Soils. Amsterdam: Ed. Elsevier. 327p.

ZUQUETTE, L.V. (1987). Análise Crítica da Cartografia Geotécnica e Proposta Metodológica para as Condições Brasileiras. (Tese de Doutorado). USP - EESC. v. 2.

ZUQUETTE, L.V. (1993). Mapeamento geotécnico: uma nova abordagem. Ribeirão Preto. Relatório Científico, FAPESP. 269p.

ZUQUETTE, L.V.; PEJON, O.J.; GANDOLFI, N.; RODRIGUES, J.E. (1997). Mapeamento geotécnico: parte 1- atributos e procedimentos básicos para elaboração de mapas e cartas. Rev. Bras. Geoc., v. 16(2), São Paulo. 
ANEXOS 
ANEXO 1

MAPA DAS BACIAS HIDROGRÁFICAS INTERCEPTADAS PELO DUTO 
ANEXO 2

MAPA DA FAIXA DE INFLUÊNCIA DO DUTO 


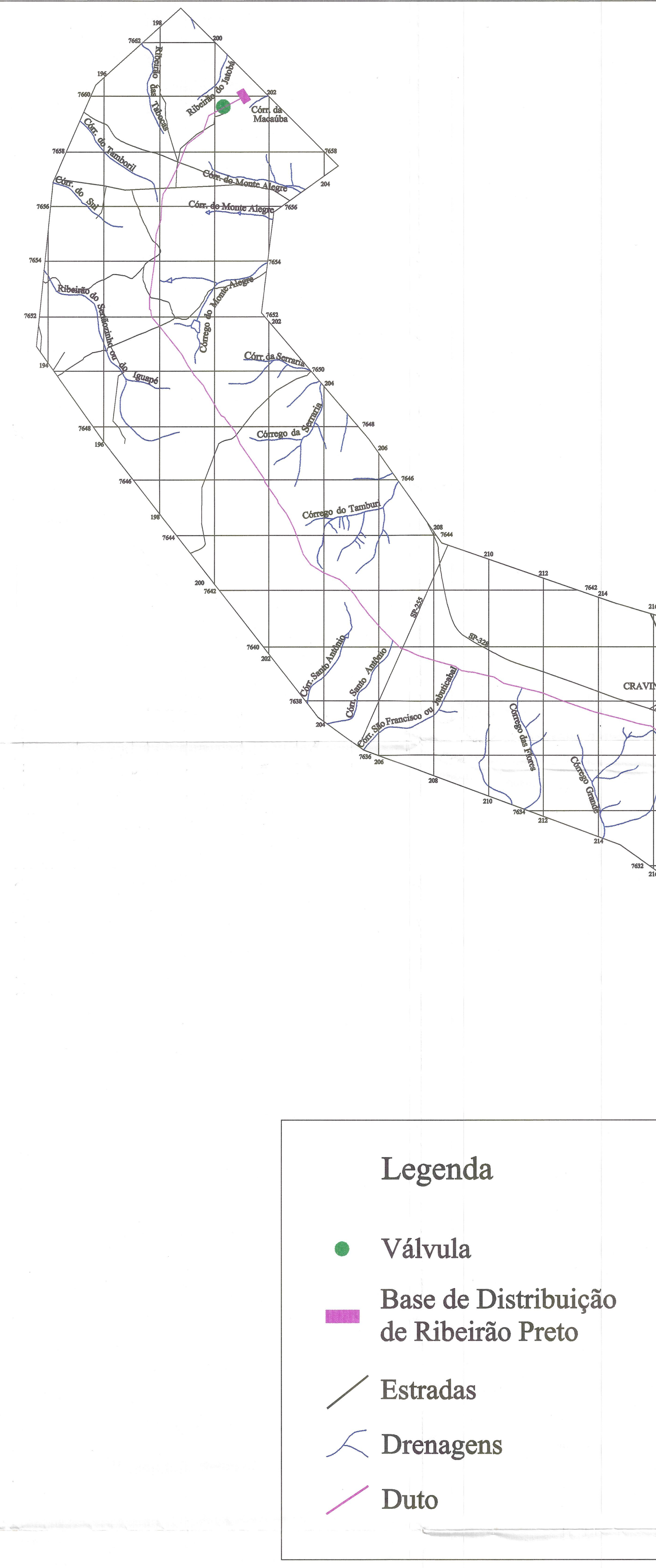

Escala Numérica 1:100.000

Escala Gráfica \begin{tabular}{llllllll}
\hline & & & & & & \\
0 & 1 & 2 & 3 & 4 & 5 & & \\
\end{tabular}

Articulação das Folhas

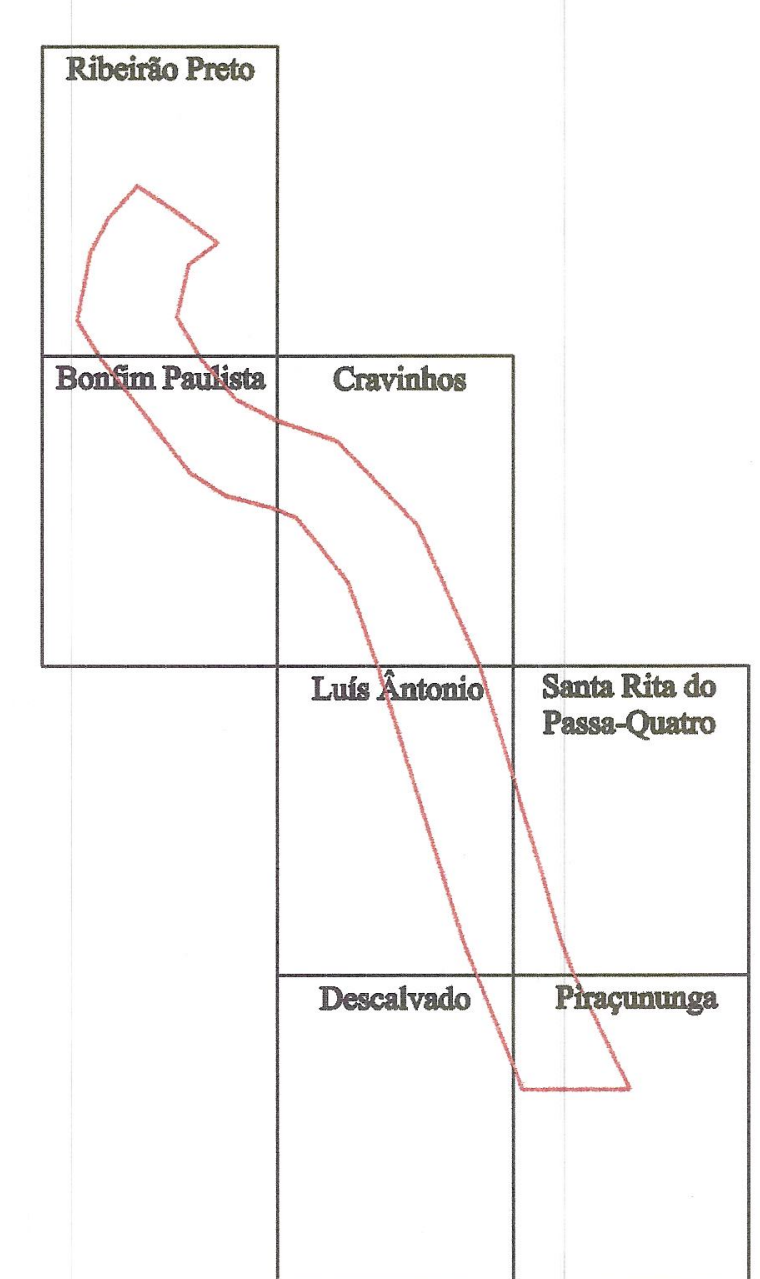

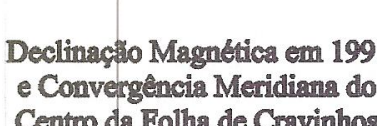

(1)

V

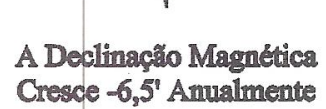

UNIVERSIDADE DE SÃO PAULO - USP

ESCOLA DE ENGENHARIA DE SÃO CARLOS - EESC DEPARTAMENTO DE GEOTECNIA

Avaliação dos Problemas Ambientais Relacionados ao Aspectos Geolóoico-Geotécnicos e Dutos Enterrados, Poliduto OSBRA: trecho Porto Ferreira - Ribeirão Preto.

AUTORA: Geól. Joseli Ferreira

ORIENTADOR: Prof. Dr. Lázaro Valentin Zuquette

ANEXO 2

MAPA DA

FAIXA DE INFLUÊNCIA 
ANEXO 3

MAPA TOPOGRÁFICO 


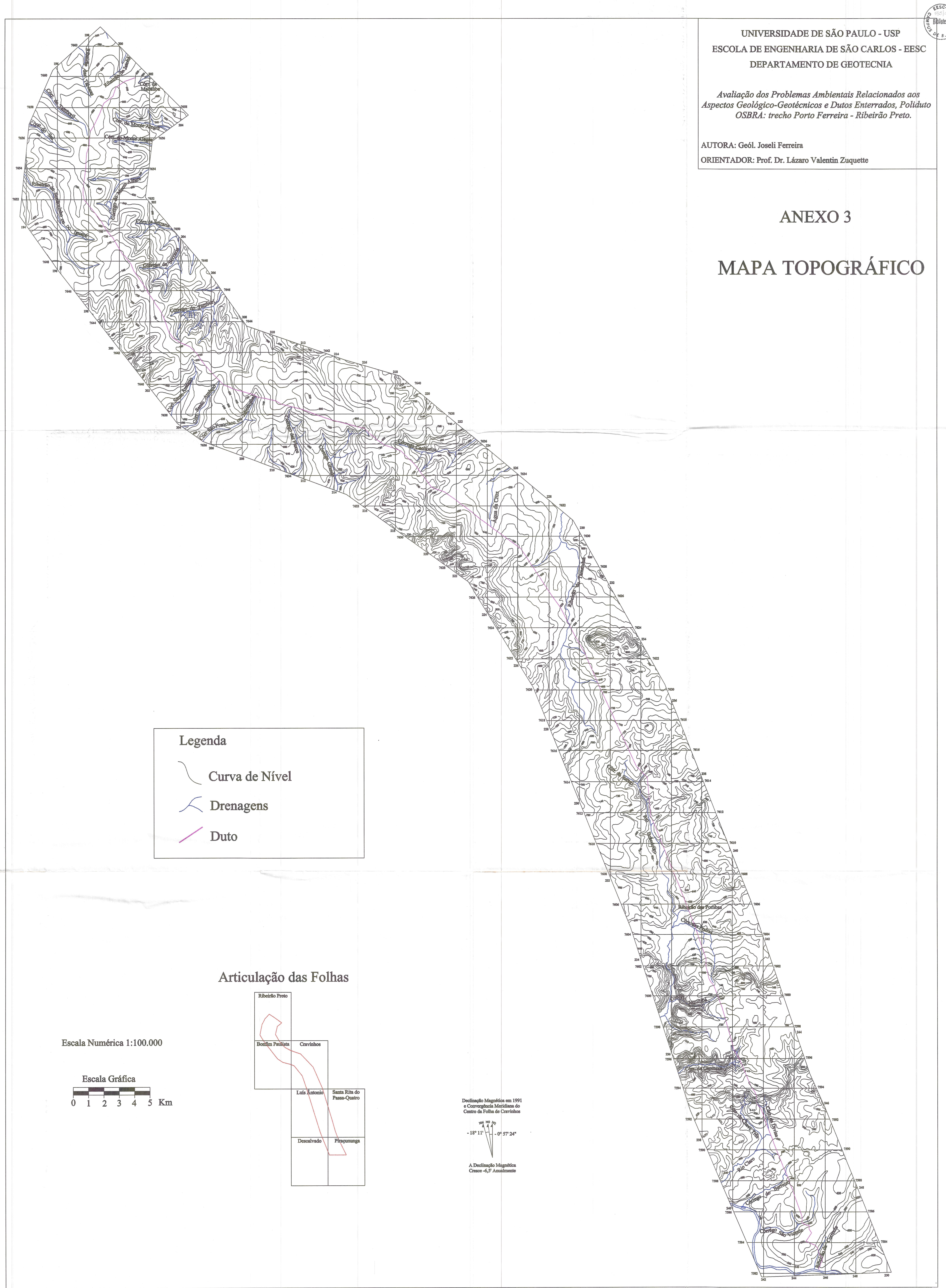


ANEXO 4

MAPA GEOLÓGICO 1 


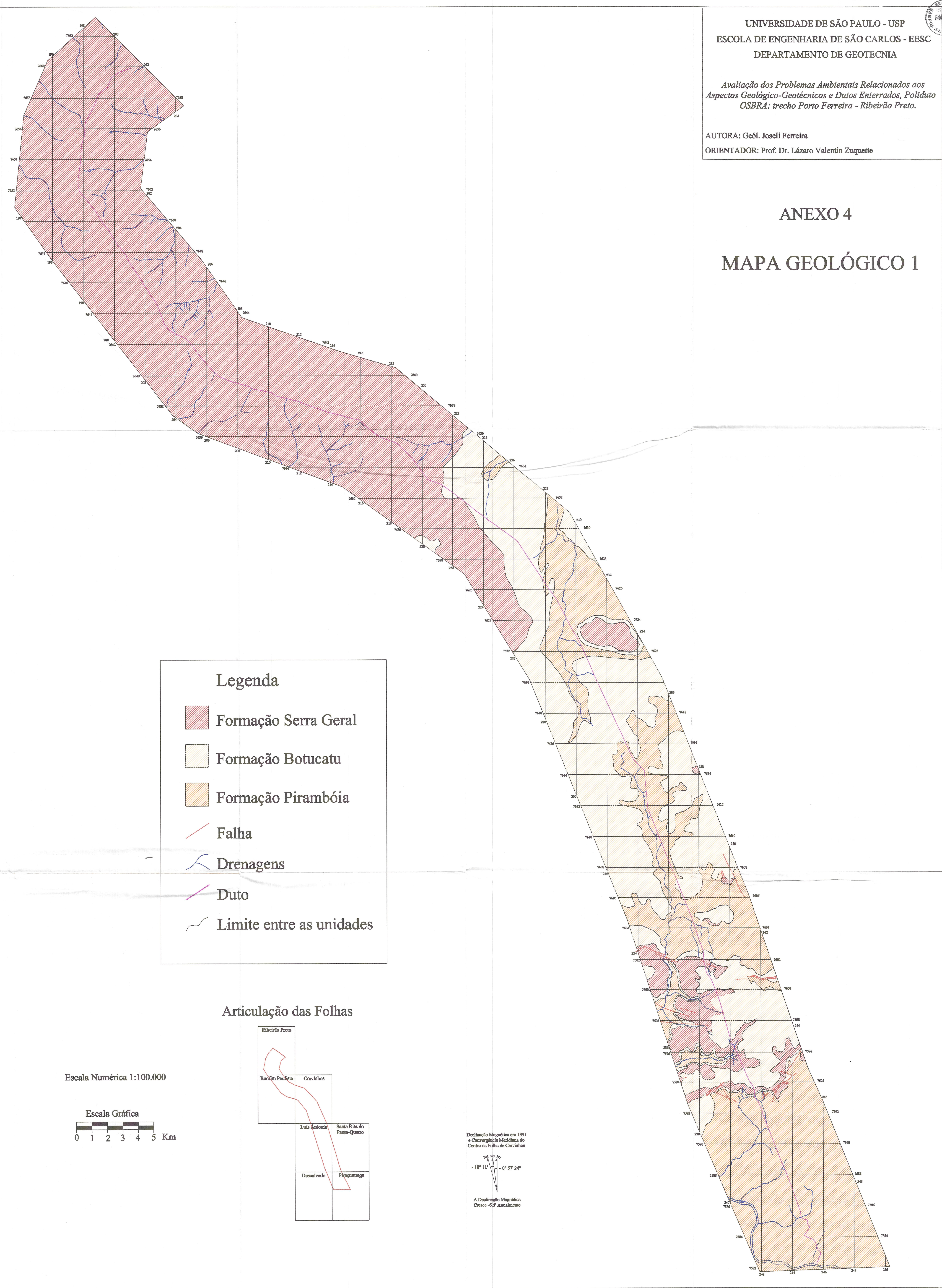


ANEXO 5

MAPA GEOLÓGICO 2 


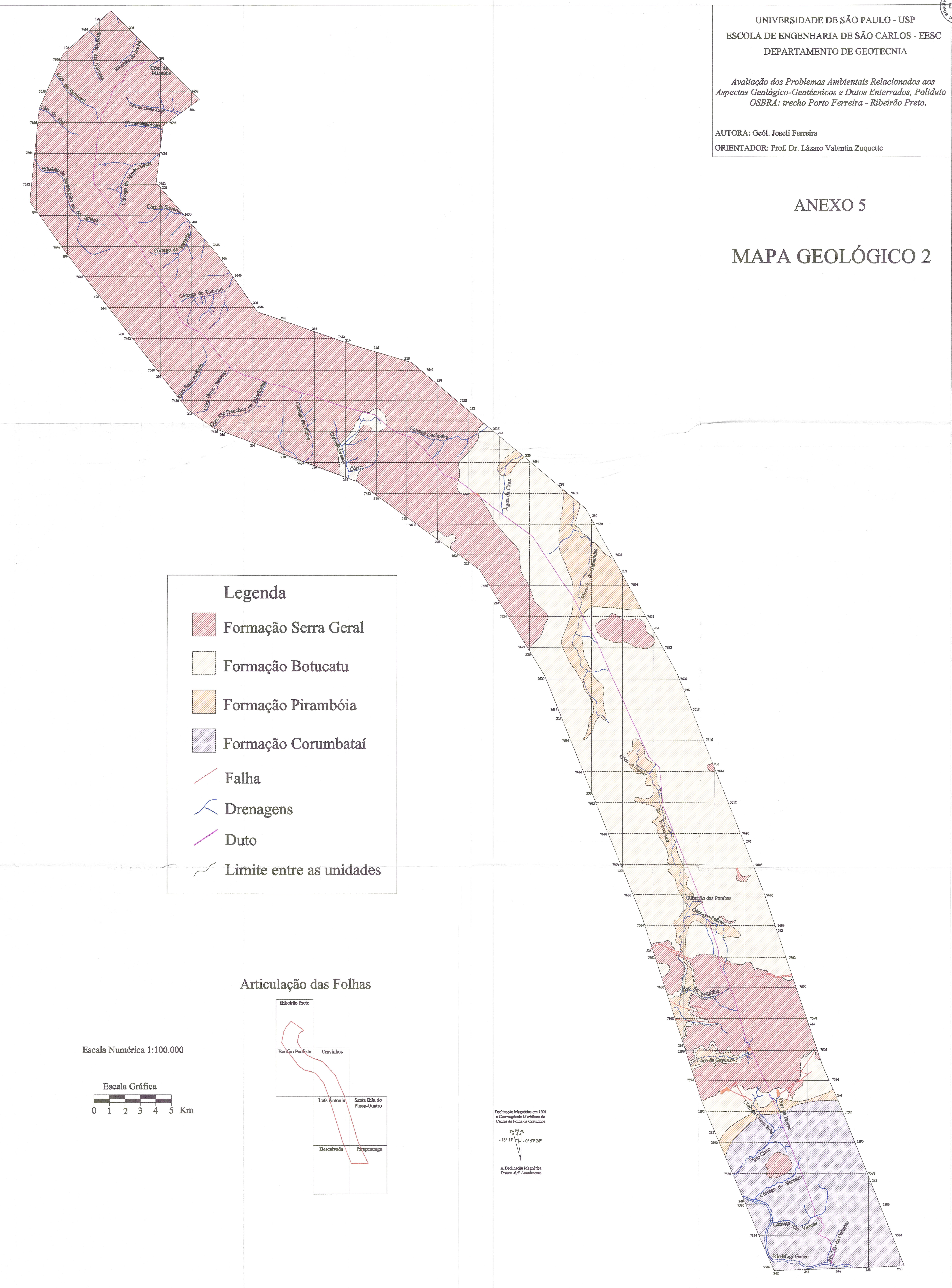


ANEXO 6

MAPA DE MATERIAIS INCONSOLIDADOS 


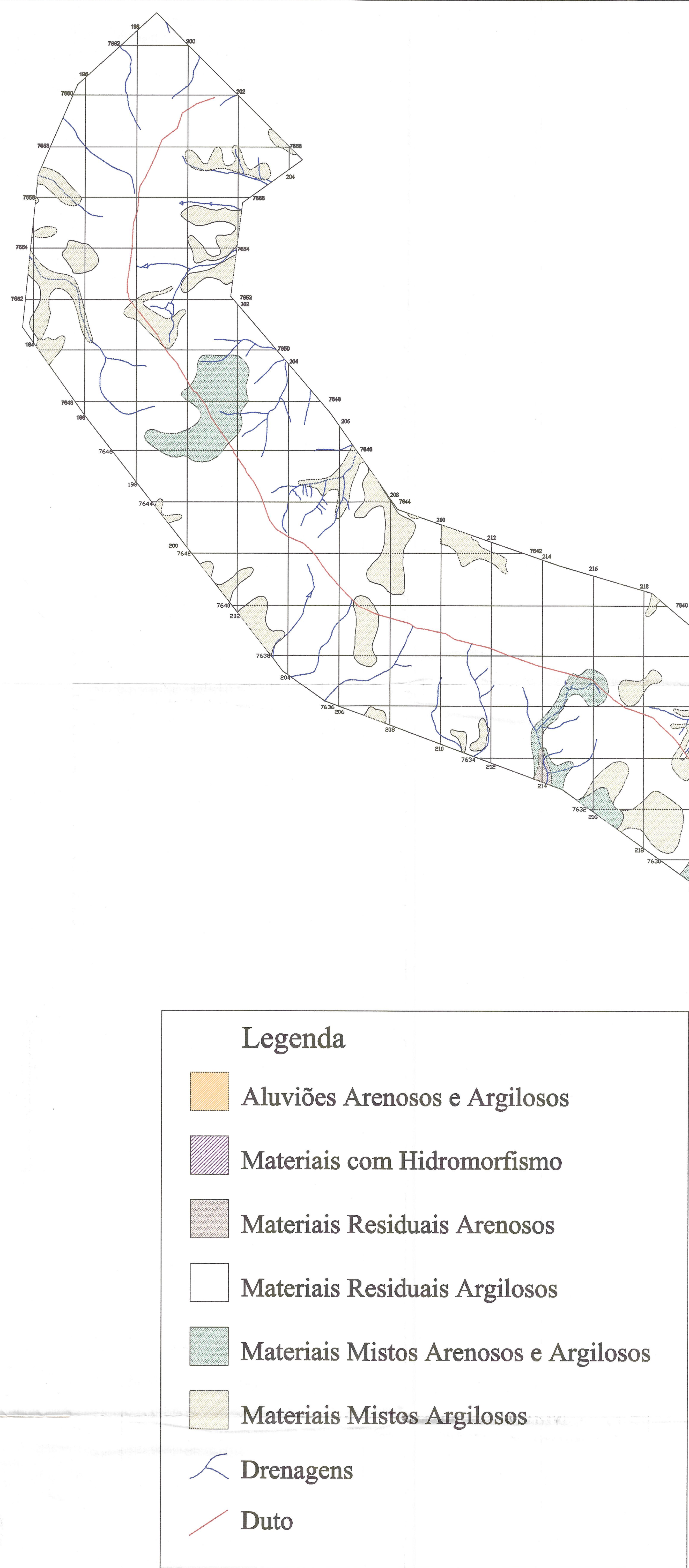

Escala Numérica 1:100.000

Escala Gráfica

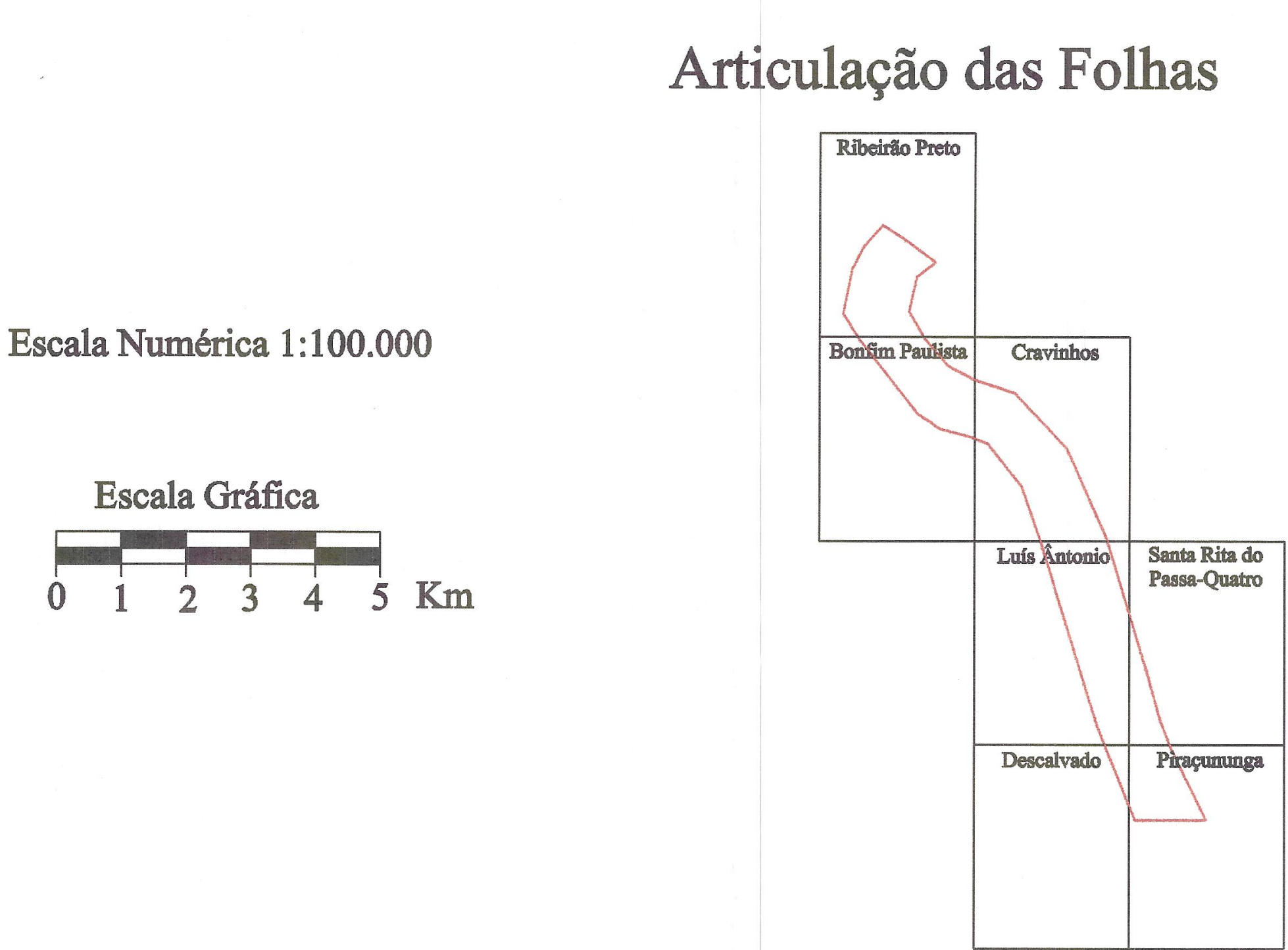

UNIVERSIDADE DE SÃO PAULO - USP ESCOLA DE ENGENHARIA DE SÃO CARLOS - EESC DEPARTAMENTO DE GEOTECNIA

Avaliação dos Problemas Ambientais Relacionados aos Aspectos Geológico-Geotécnicos e Dutos Enterrados, Poliduto OSBRA: trecho Porto Ferreira - Ribeirão Preto.

AUTORA: Geól. Joseli Ferreira

ORIENTADOR: Prof. Dr. Lázaro Valentin Zuquette

\section{MAPA DE MATERIAIS INCONSOLIDADOS}


ANEXO 7

MAPA DE PROFUNDIDADE DO SUBSTRATO ROCHOSO 
NÃO LOCALIZADO NO EXEMPLAR IMPRESSO 
ANEXO 8

\section{PERFIL GEOLÓGICO- GEOTÉCNICO 1}


ANEXO 9

\section{PERFIL GEOLÓGICO- GEOTÉCNICO 2}




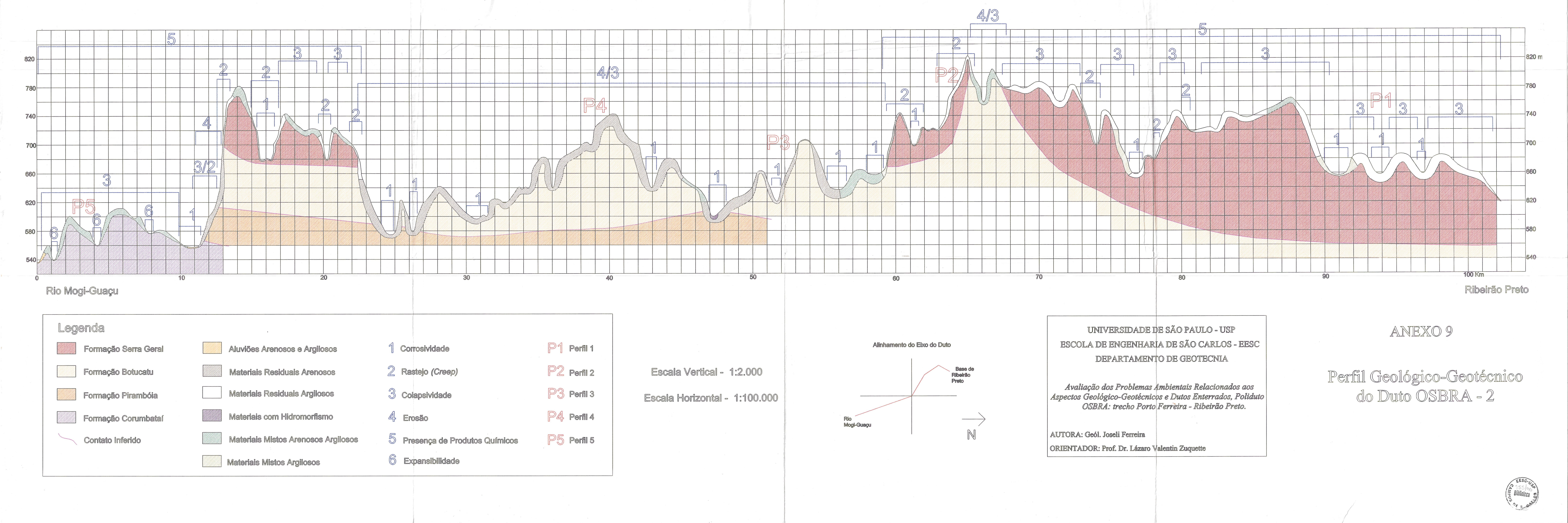


ANEXO 10

CARTA DE ZONEAMENTO GEOLÓGICO-GEOTÉCNICO 
AUTORA: Gébl. Joseli Ferreira

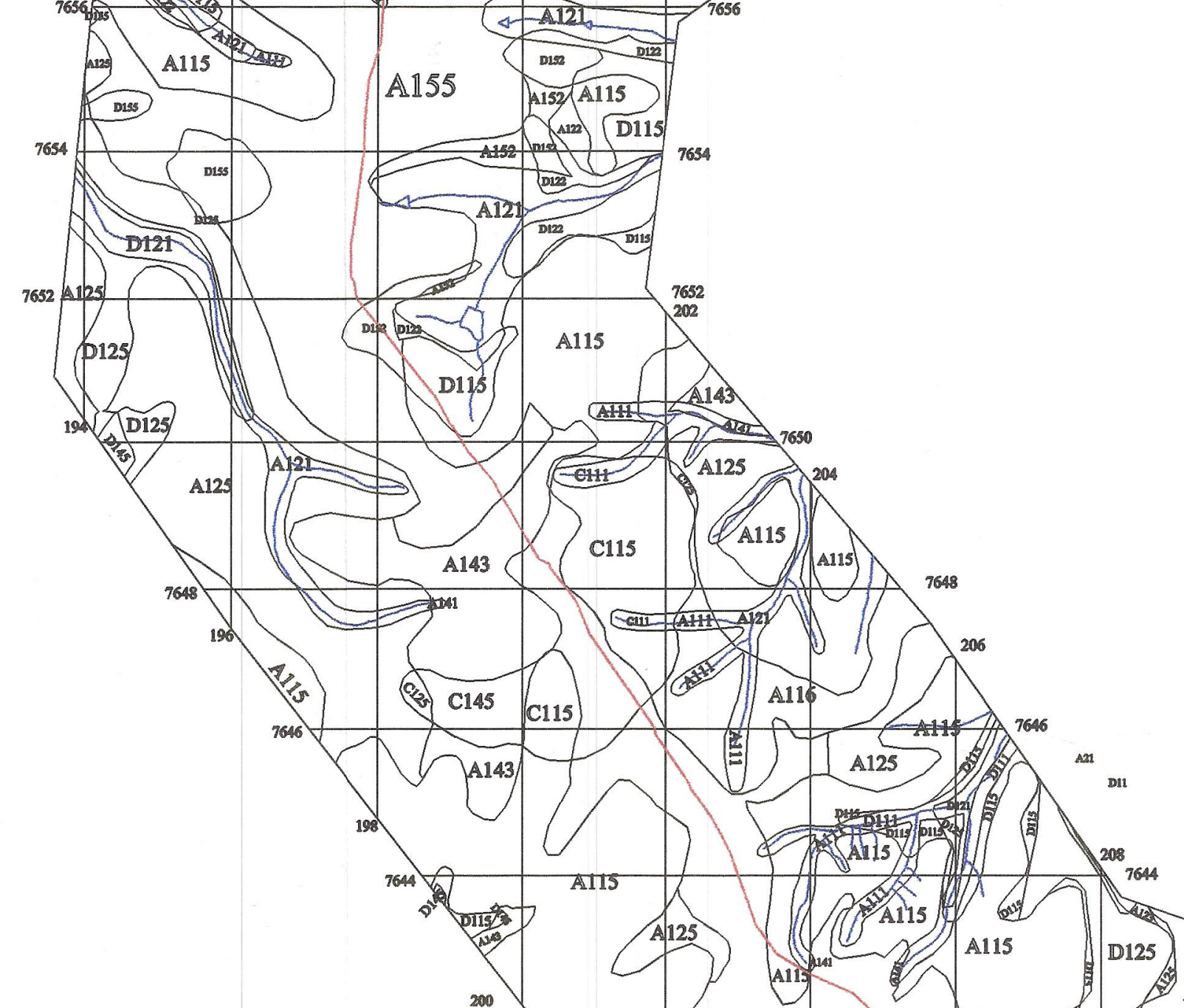

ORIIENTADOR: Prof. Dr. Ĺfzaro Valentin Zuqueette

ANEXO 10

Legenda

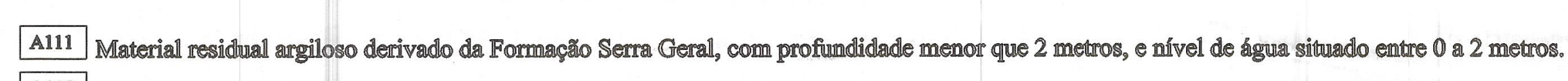

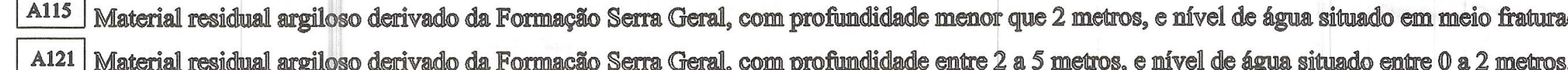

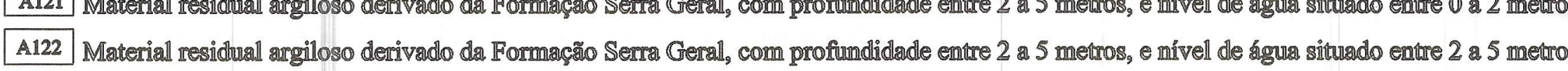

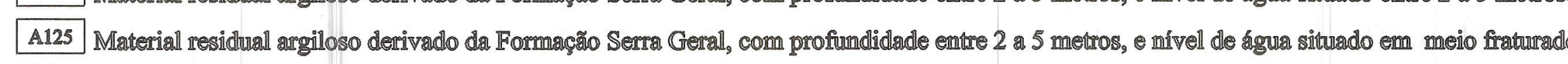

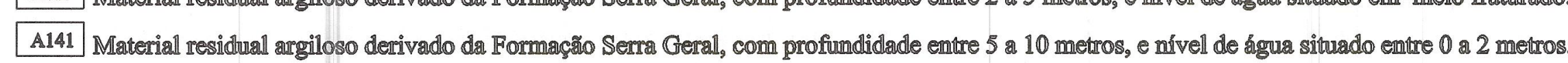

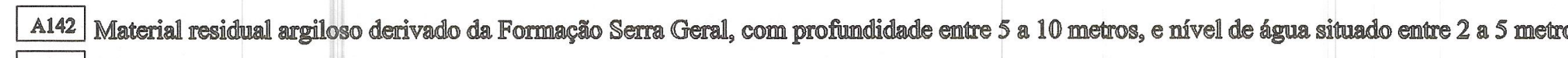

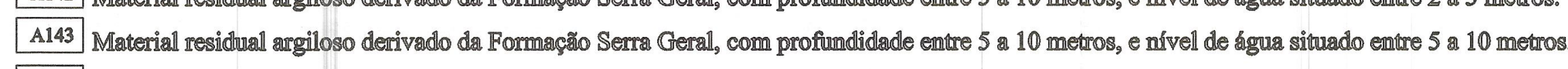

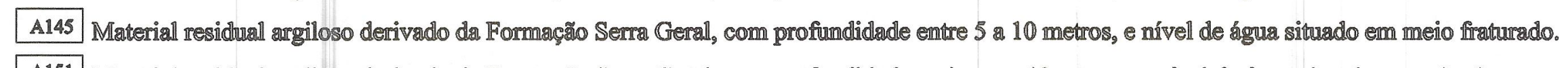

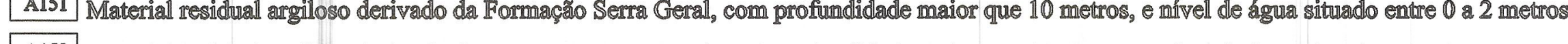

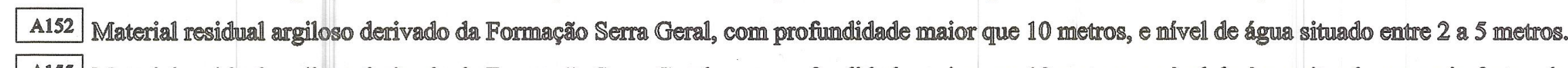

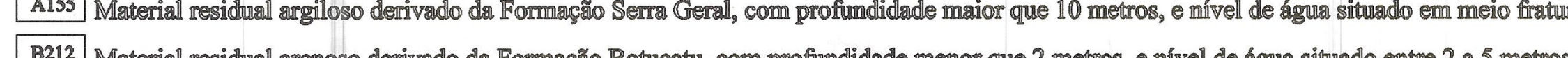

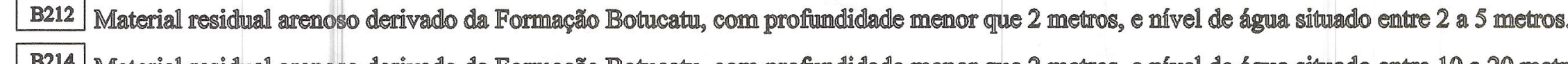

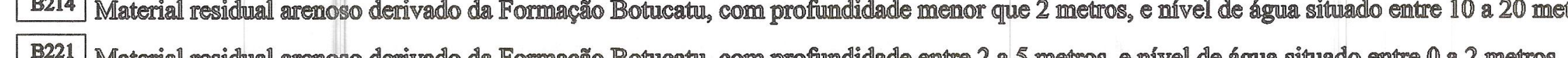
B2227 Material

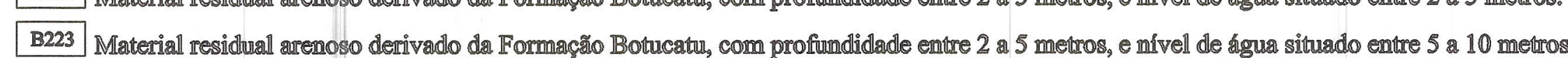

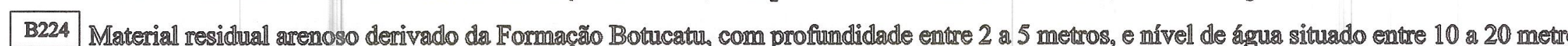
B231 Materil

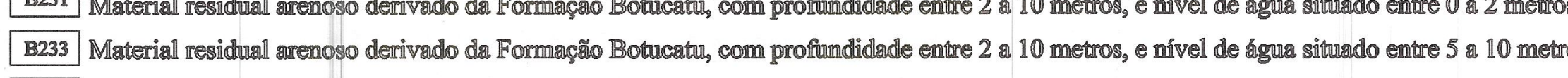

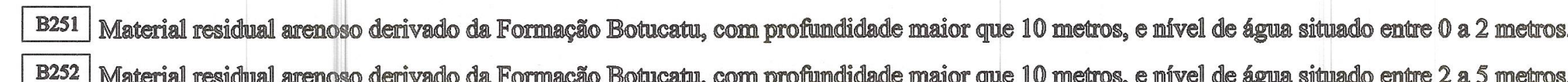

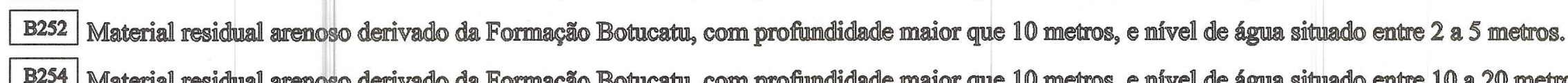

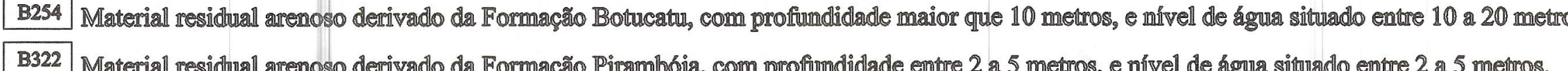

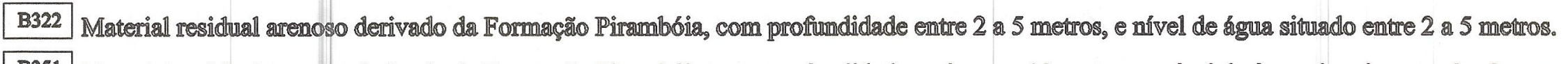

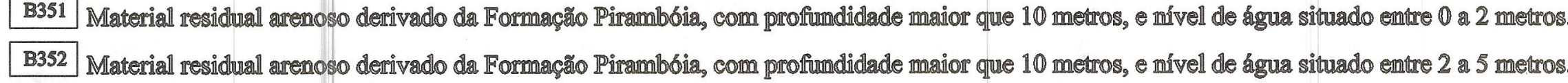

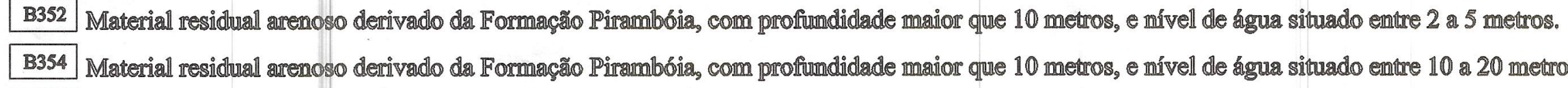

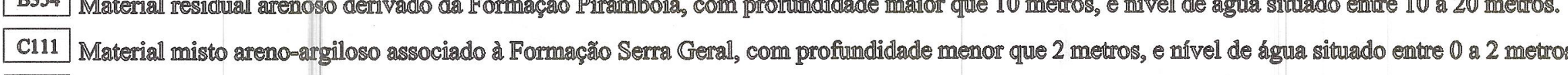

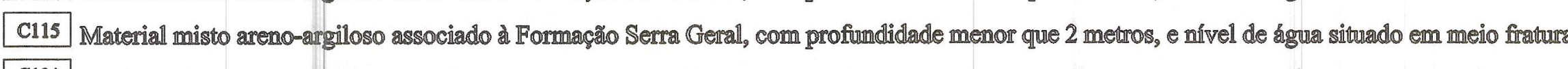

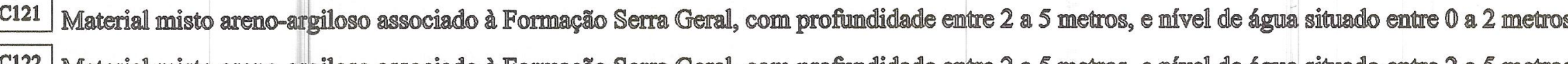

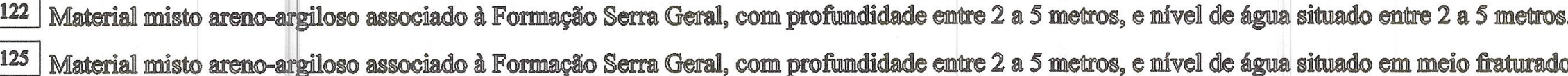

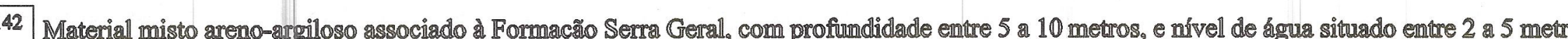

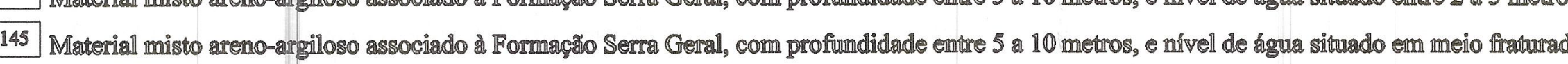

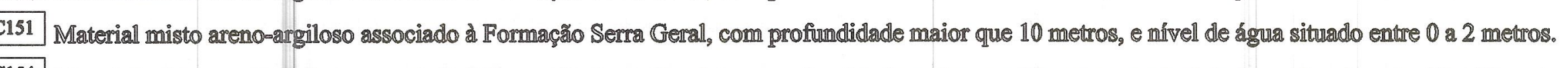

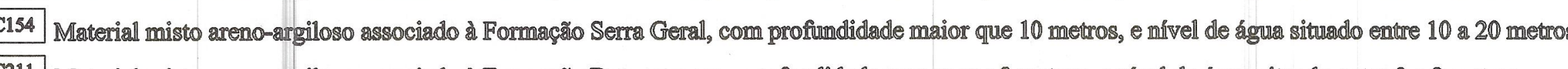

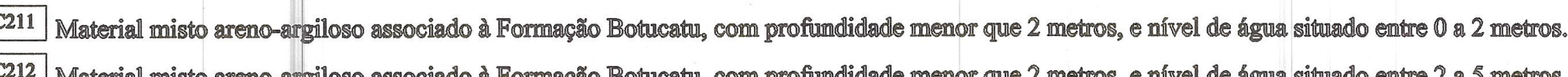

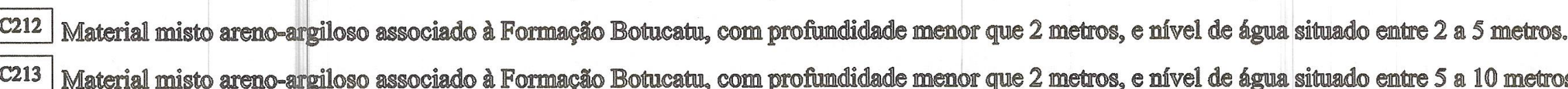

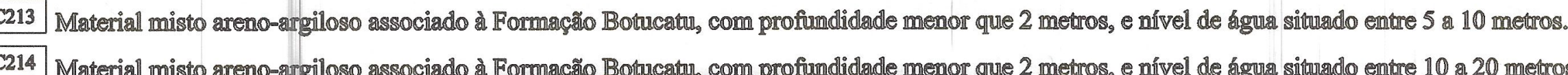

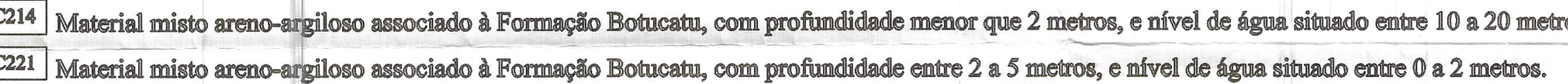

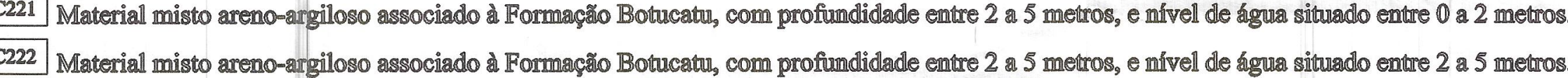

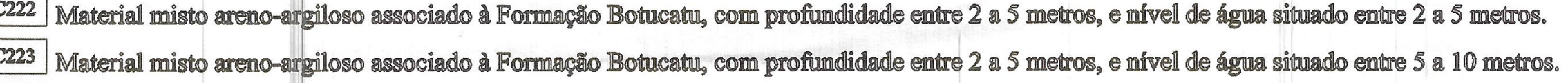

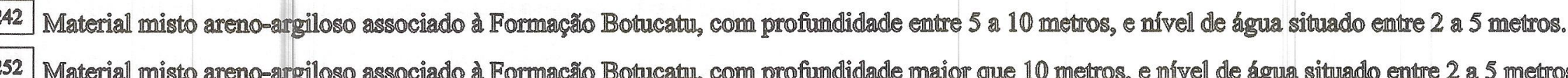

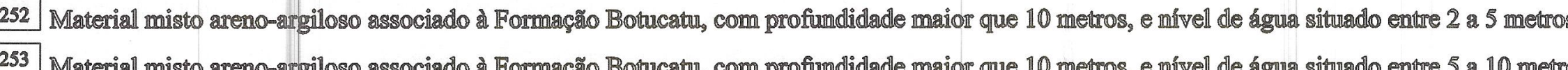

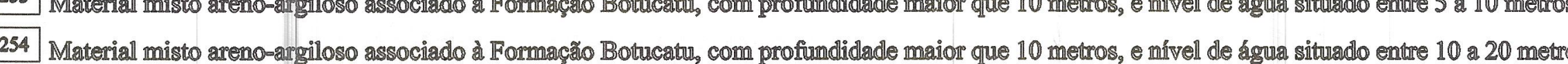

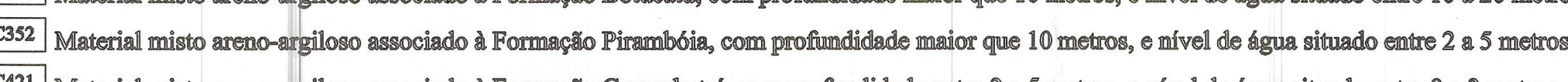

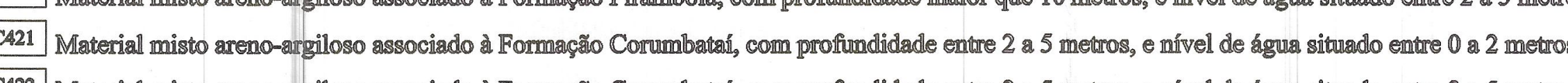

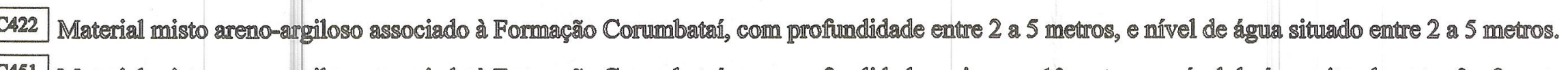

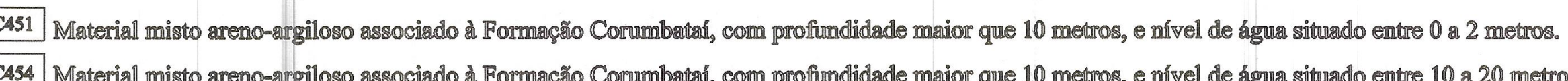

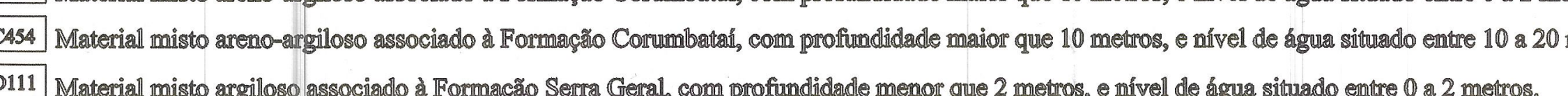

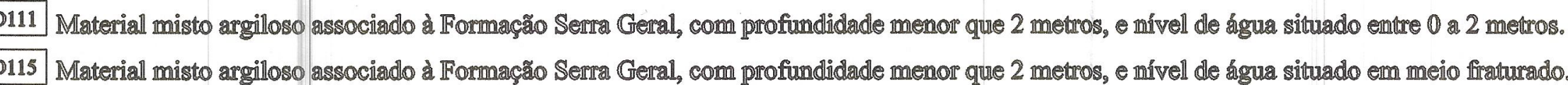

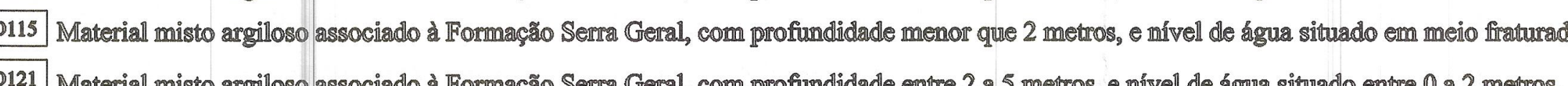

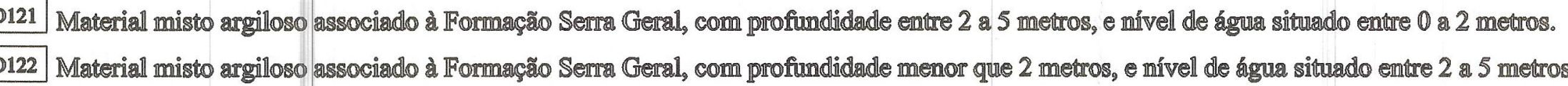

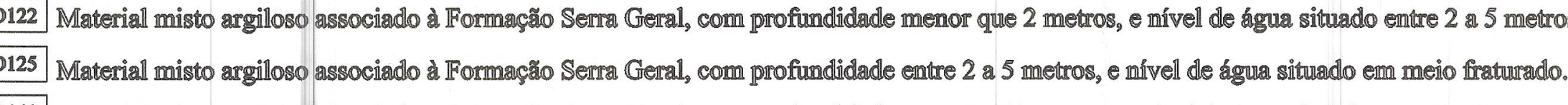

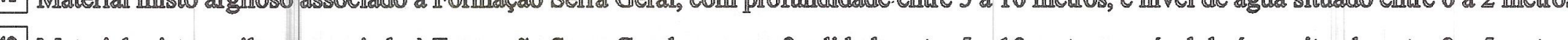
Mat

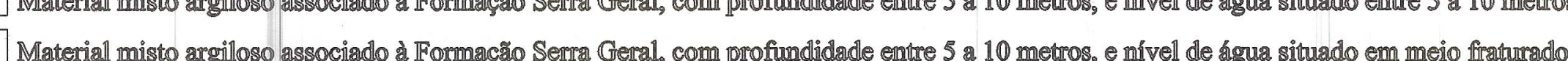

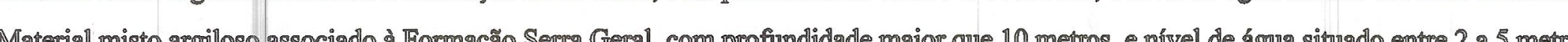

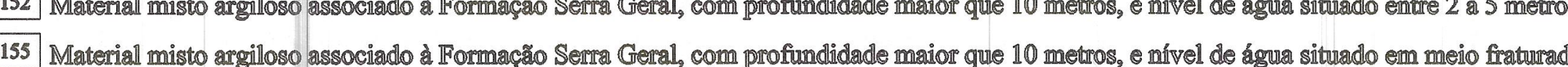

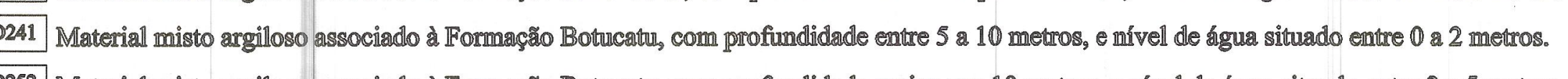

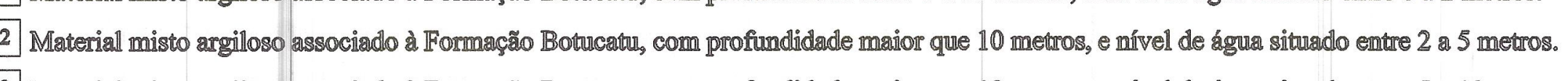

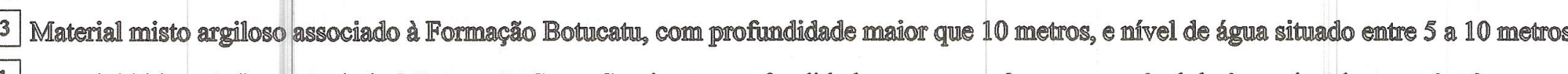

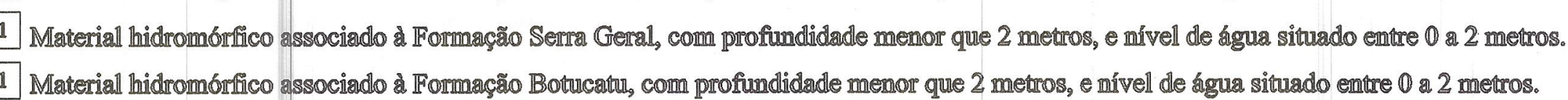

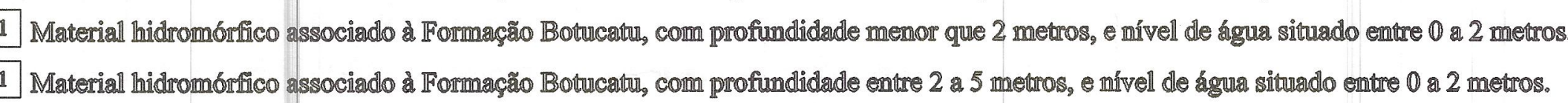

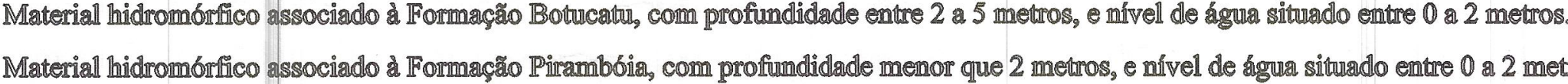

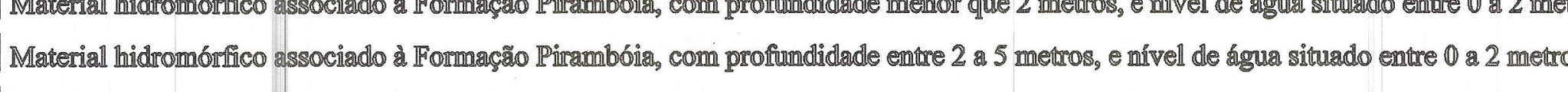

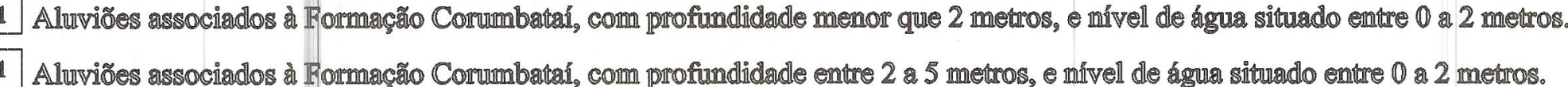

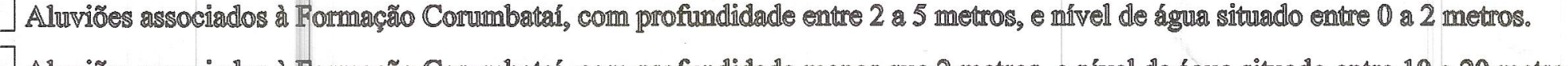
Drenagens

Articullação das Follhas

Escalla Numérical 1:100.000

Escalla Grafifica

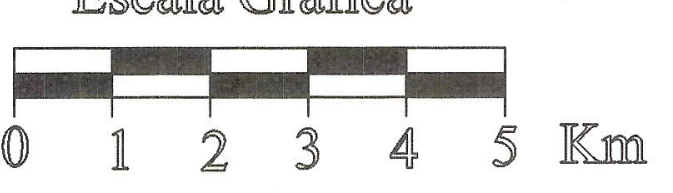

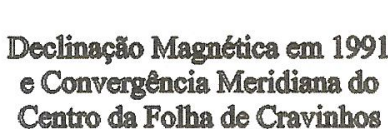

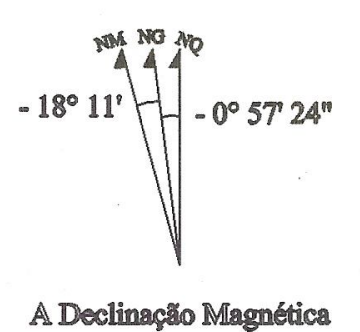

CARTA DE ZONEAMIENTO GEOLÓGICO-GHETERCNICO

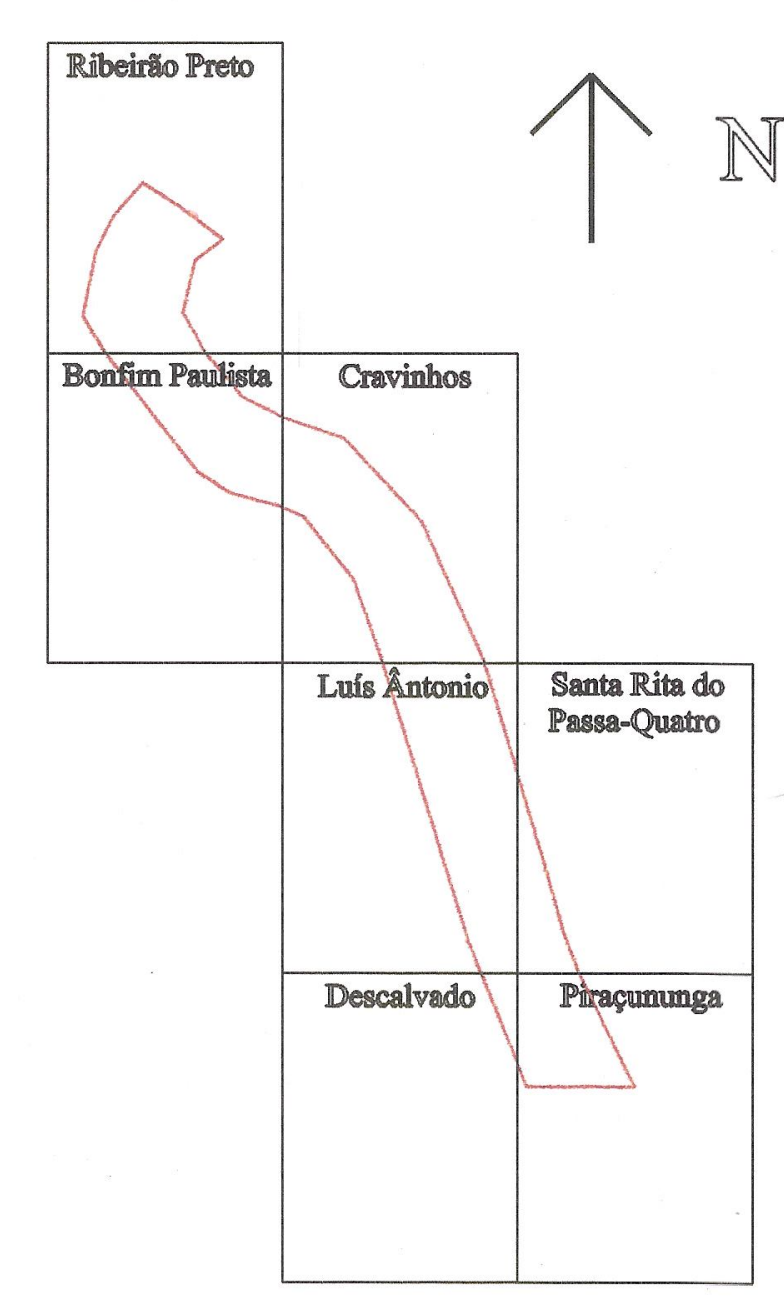

